OSSANDÓN, María Magdalena. "La técnica de las definiciones en la ley penal:

Análisis de la definición de "material pornográfico en cuya elaboración hubieren sido utilizados menores de dieciocho años".

Polit. crim. Vol. 9, No 18 (Diciembre 2014), Art. 1, pp. 279-337.

[http://www.politicacriminal.cl/Vol_09/n_18/Vol9N18A1.pdf]

\title{
La técnica de las definiciones en la ley penal. Análisis de la definición de "material pornográfico en cuya elaboración hubieren sido utilizados menores de dieciocho años"
}

\author{
María Magdalena Ossandón Widow \\ Doctora en Derecho, Universidad de Navarra \\ Profesora de Derecho penal, Pontificia Universidad Católica de Chile \\ mossandonw@uc.cl
}

\begin{abstract}
Resumen
El recurso a una definición legal es una técnica legislativa poco empleada en nuestra legislación penal, que podría servir para lograr una mayor seguridad jurídica y reducir las posibilidades de interpretación judicial. En este trabajo hacemos un análisis de la definición de material pornográfico en cuya elaboración hubieren sido utilizados menores de dieciocho años para determinar si es una técnica adecuada, tanto desde una perspectiva formal como en relación con su contenido. Previamente, hemos tenido que revisar lo que se entiende por una definición legal así como sus características más relevantes.
\end{abstract}

Palabras clave: Material pornográfico infantil, definición legal, técnica legislativa.

\begin{abstract}
The resort to a legal definition is a legislative technique seldom used in our criminal law, which could be used to achieve greater legal certainty and reduce the possibilities of judicial interpretation. In this paper we analyze the definition of pornographic material whose production have been used of minors under eighteen years to determine if it is a proper technique from a formal perspective and in relation to its content. Previously, we had to review what is meant by legal definition and its most important characteristics.
\end{abstract}

Key words: Child pornography, Legislative Definition, Legislative Drafting.

\section{Introducción}

La descripción típica en los delitos relacionados con la pornografía se ve enfrentada a particulares dificultades en la delimitación de lo penalmente prohibido. Por una parte, porque la configuración de delitos en este ámbito se contrapone, por ejemplo, con el derecho a la libertad de expresión y la creación artística. Y por otra, porque la delimitación de lo que se considera pornográfico parece radicalmente condicionada por las creencias y sensibilidad de las personas y, en general, por las costumbres de una época y lugar determinados. 
OSSANDÓN, María Magdalena. "La técnica de las definiciones en la ley penal: Análisis de la definición de "material pornográfico en cuya elaboración hubieren sido utilizados menores de dieciocho años".

Estas características hacen que resulte especialmente pertinente un estudio sobre la técnica legislativa a la que ha recurrido el legislador para abordar esta materia. Específicamente, nuestra atención va a recaer sobre una herramienta utilizada en este ámbito: la definición de lo que se entiende por material pornográfico en cuya elaboración hubieren sido utilizados menores de dieciocho años contenida en el inciso segundo del art. 366 quinquies de nuestro Código penal (en adelante, "CP”).

\section{Técnica legislativa, dogmática jurídica y política criminal}

El recurso a una definición es una práctica poco empleada y que, por lo mismo, debe ser convenientemente analizada. Nuestro objetivo es examinarla desde la perspectiva de su idoneidad y funcionalidad, considerando que al adoptar una determinada técnica legislativa se ha de buscar la optimización en la redacción del texto normativo, en diversos sentidos que analizaremos luego- para lo cual el aspecto formal resulta esencial. En otras palabras, no vamos a hacer un estudio referido única ni principalmente a los delitos sexuales, sino que un análisis de la forma que ha empleado el legislador en la redacción del texto normativo. Pero, asumido este punto de vista, no podemos olvidar que la forma de una disposición jurídica no es independiente de su contenido -la forma no existe por sí sola, sino en función de la norma que contiene ${ }^{1}-$, y en este sentido, el contenido material de la definición que analizaremos es relevante para las decisiones de técnica legislativa, en un triple nivel: porque es una definición que se enmarca dentro del Derecho penal, porque se utiliza para la tipificación de un delito y porque se refiere, específicamente, al ámbito de los delitos sexuales cometidos contra menores de edad.

En cuanto a lo primero, no parece necesario detenernos a considerar la especial importancia que tiene la forma en que se redacte una disposición para el Derecho penal, una rama del ordenamiento jurídico que se caracteriza por constituir una reacción punitiva formalizada, ${ }^{2}$ sometida a los límites estrictos que impone el principio de legalidad, en tensión con el objetivo de brindar la necesaria protección a los bienes jurídico-penales. ${ }^{3}$ Dentro del ámbito

\footnotetext{
* Trabajo redactado en el marco del Proyecto Fondecyt № 1121195 "Producción, difusión y almacenamiento de material pornográfico: estudio dogmático y crítico", dirigido por el Prof. Dr. Luis Rodríguez Collao en la Pontificia Universidad Católica de Valparaíso.

${ }^{1}$ La forma es parte del contenido, en tanto en cuanto constituye su apariencia visible: "Die Form gehört zum Inhalt, sie ist 'der Inhalt von seiner Sichtbarkeit", afirma -citando a Ihering- TIEDEMANN, Klaus, Tatbestandsfunktionen im Nebenstrafrecht, Tübingen: J. C. B. Mohr, 1969, p. 73 (destacado en el original). La indisolubilidad entre forma y fondo constituye, también, conclusión y premisa de los estudios de técnica legislativa; vgr. LASSERRE-KIESOW, Valérie, La technique législative. Étude sur les Codes Civils français et allemand, Paris: Librairie Générale de Droit et de Jurisprudence, 2000, pp. 127-146, y NAVARRO FRIAS, Irene, "Técnica legislativa y Derecho penal", Estudios Penales y Criminológicos, vol. XXX (2010), pp. 219267, pp. 238-243.

2 SILVA SÁNCHEZ, Jesús María, Aproximación al Derecho penal contemporáneo, Barcelona: Bosch, 1992, pp. 250 y ss., advierte que lo singular del Derecho penal como medio de control social no radica en lo punitivo, sino en lo jurídico y, en concreto, en el alto grado de formalización que esto supone.

${ }^{3}$ Aunque desde un punto de vista garantístico los principios de ofensividad y legalidad no tienen que estar en contradicción sino que deben conjugarse y compenetrarse, para que el delito se configure, precisamente, como un hecho ofensivo típico, en expresión de MANTOVANI, Ferrando, "Il principio di offensività nello schema di delega legislativa per un nuovo Codice Penale", Rivista italiana di Diritto e Procedura Penale (1997), pp.
} 


\section{Polít. crim. Vol. 9, No 18 (Diciembre 2014), Art. 1, pp. 279-337. \\ [http://www.politicacriminal.cl/Vol_09/n_18/Vol9N18A1.pdf]}

penal, la redacción de cada precepto debe responder a una racionalidad específica, que por más técnica que sea no puede desatender su sustrato valorativo, que nutre y desarrolla cada una de las decisiones legislativas concretas, tanto en el fondo como en la forma. ${ }^{4}$

Pero lo anterior puede tener un sentido diverso según la clase de precepto de que se trate, aún dentro del sistema penal. No es lo mismo, por ejemplo, crear un tipo delictivo, introducir una causa de justificación o establecer una circunstancia atenuante general, pues la naturaleza jurídica de un precepto penal puede determinar una diferente relación con un principio jurídico como, en lo que aquí más interesa, el principio de legalidad. ${ }^{5}$ Ello se debe a que, en los ejemplos propuestos, los tipos, las causas de justificación y las circunstancias modificatorias de responsabilidad penal pertenecen a distintas categorías, las que "se sujetan a distintos principios y cumplen diferentes funciones político-criminales, y [que] tales principios y funciones deben orientar ya -en aras de una mayor racionalidad- la redacción de los preceptos según se integren en una u otra categoría jurídico-penal". 6

Y en tercer lugar, que estemos analizando una definición formulada en el contexto de los delitos sexuales y con víctimas menores de edad es relevante en la medida en que, en general, la técnica legislativa utilizada está condicionada por la lógica propia de las figuras específicas, en relación con el particular interés u objeto de tutela jurídico penal. "Todo bien jurídico condiciona y orienta de forma decisiva la configuración de la figura delictiva con la que se pretende - mediata o inmediatamente- su protección". 7 Así, por ejemplo, la descripción típica deberá ser diferente según si estamos ante un bien jurídico individual o

313-337, pp. 315-316. Por lo demás, el principio de ofensividad, aunque relacionado con la finalidad de protección del Derecho penal, también debe entenderse como límite, pues "la necesaria lesividad del resultado (...) condiciona toda justificación utilitarista del Derecho penal como instrumento de tutela y constituye su principal límite axiológico externo", FERRAJOLI, Luigi, Derecho y razón. Teoría del garantismo penal, trad.: ANDRÉS IBÁÑEZ, Perfecto et al., Madrid: Trotta, 1995, p. 467.

${ }^{4}$ NAVARRO FRIAS, “Técnica legislativa”, cit. nota $\mathrm{n}^{\circ}$ 1, p. 232, destaca la necesidad de adaptar no solo la técnica legislativa, sino que también la teoría de la legislación a las diversas ramas del ordenamiento jurídico

${ }^{5}$ En este sentido SÁNCHEZ LÁZARO, Fernando-Guanarteme, "¿Cómo se elabora una propuesta de lege ferenda? Reflexiones sobre la formulación de los preceptos jurídico-penales. Primera parte: tipicidad",

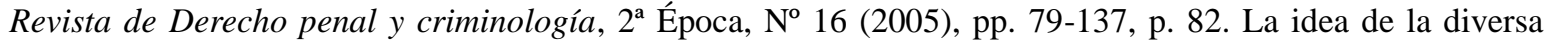
intensidad del principio de legalidad en la tipicidad y en la justificación había sido propuesta ya por ROXIN, Claus, Política criminal y sistema del Derecho penal, $2^{\mathrm{a}}$ ed., trad. MUÑOZ CONDE, Francisco, Buenos Aires: Hammurabi, 2000, pp. 58-59. En el Derecho penal inglés esta diferencia se ha hecho particularmente patente, pues "mientras la Parte General se mantiene estrechamente ligada al common law, la evolución del statute law en la configuración de la Parte Especial demuestra que la exigencia de una clara predeterminación de la conducta prohibida es una aspiración básica del principio de legalidad en Inglaterra", PALAZZO, Francesco, "La legalidad en la Europa de Amsterdam", trad.: GARCÍA RIVAS, Nicolás, Revista penal, № 3 (1999), pp. 36-41, p. 37. La mejor expresión de esta y otras diferencias es la radical propuesta de Robinson de codificar el Derecho penal en dos textos diferentes, uno para tipificar las conductas prohibidas y otro para las normas de enjuiciamiento; cfr. ROBINSON, Paul H., "Rules of Conduct and Principles of Adjudication", Chicago Law Review 57 (1990), pp. 729-771, y especialmente ROBINSON, Paul H.; GREENE, Peter D.; GOLDSTEIN, Natasha R., "Making Criminal Codes Functional: A Code of Conduct and a Code of Adjudication", The Journal of Criminal Law and Criminology 86 (1996), pp. 304-365.

6 SÁNCHEZ LÁZARO, “Cómo se elabora...?”, cit. nota n ${ }^{\circ}$ 5, pp. 82-83, adaptando al ámbito de la técnica legislativa la propuesta de Roxin de integrar la política criminal en las consideraciones de la dogmática penal. De acuerdo con ello, por lo que propone profundizar en una dogmática penal de lege ferenda, NAVARRO FRIAS, “Técnica legislativa", cit. nota nº 1, pp. 251-252.

${ }^{7}$ SÁNCHEZ LÁZARO, “CCómo se elabora...?”, cit. nota nº 5, p. 127. 
OSSANDÓN, María Magdalena. "La técnica de las definiciones en la ley penal:

Análisis de la definición de "material pornográfico en cuya elaboración hubieren sido utilizados menores de dieciocho años".

supraindividual, según los modos en que puede verse afectado el interés, según si se alude a una realidad extrapenalmente regulada, etc.

En consecuencia, la discusión sobre técnica legislativa en materia penal debe empaparse de las consideraciones de dogmática jurídica y política criminal, en atención a las necesidades y características del sistema penal, de la descripción de tipos penales y del grupo específico de delitos de que se trata, para así conseguir la óptima configuración de la ley a que se aspira. Esta clase de examen es el que realizaremos en lo que sigue, a propósito del "ejemplo" que ofrece la definición del art. 366 quinquies CP.

\section{Definiciones de pornografía infantil}

Doctrinariamente se suele distinguir varias clases de pornografía infantil. En primer lugar está la pornografía clásica que se refiere a aquellas representaciones en que han intervenido menores reales, sin manipulación de imagen y en un contexto pornográfico real, aunque la representación de una actividad sexual pueda ser simulada. Y por otra parte, la denominada pornografía alusiva a menores que puede definirse como aquella en cuya elaboración no se utiliza realmente a menores de edad o, utilizándolos, se lo hace solo de manera indirecta. ${ }^{8}$

Dentro de la alusiva a menores existen tres clases bien identificables, aunque su denominación varíe entre los autores: la pornografía técnica, la pornografía virtual y la pseudopornografía. ${ }^{9}$ La primera es aquella que se consigue con participación de adultos cuya imagen es alterada para que parezcan menores de edad (suavizando sus facciones, eliminando el vello púbico o facial, usando ciertas vestimentas, etc.). La pornografía virtual o artificial es aquella generada íntegramente en el ordenador. La pseudopornografía, por último, es aquella en que se insertan las voces, fotogramas o imágenes de menores reales identificables, en contextos pornográficos.

Frente a esta variedad de supuestos enmarcada en un complejo y mudable escenario tecnológico, se ha planteado la necesidad de incluir en la ley penal de una definición sobre material pornográfico en cuya elaboración hubieren sido utilizados menores de dieciocho años, decisión que también ha estado condicionada en gran medida por la preocupación internacional de perseguir y sancionar toda conducta relacionada con la pornografía infantil. ${ }^{10}$ Por eso, antes de analizar nuestra ley revisaremos la situación en derecho internacional y comparado.

\footnotetext{
${ }^{8}$ Cfr. DE LA FUENTE JIMÉNEZ, Claudia, Delitos de pornografía infantil, Santiago: Legal Publishing, 2008, p. 120 y MOLINA CANTILLANA, René, Delitos de pornografía infantil, Santiago: Librotecnia, 2008 , p. 72.

${ }^{9}$ Vid. por todos, MORILLAS FERNÁNDEZ, David Lorenzo, Análisis dogmático y criminológico de los delitos de pornografía infantil, Madrid: Dykinson, 2005, pp. 69 y 70, y entre nosotros, KÜNSEMÜLLER, Carlos, "Delitos de pornografía infantil (modificaciones legales anunciadas y problemas ad portas)", Gaceta Jurídica $\mathrm{N}^{\mathrm{o}} 273$ (2003), pp. 7-13, p. 12.

${ }^{10}$ Por su alcance tal vez se podría hablar de material pornográfico infanto-juvenil y de pornografía del mismo carácter, según CISTERNAS VELIS, Luciano Alberto, El delito de producción de pornografía infanto-juvenil como lesión a la intimidad y el honor de los menores de edad. Análisis doctrinal de las consecuencias en el ámbito concursal, Valparaíso: Tesis de Magíster, Pontificia Universidad Católica de Valparaíso, 2013, p. X. Sin embargo, aplicando la definición del artículo $1^{\circ}$ de la Convención sobre los Derechos del Niño, que
} 


\section{Polít. crim. Vol. 9, No 18 (Diciembre 2014), Art. 1, pp. 279-337. \\ [http://www.politicacriminal.cl/Vol_09/n_18/Vol9N18A1.pdf]}

Ya en 1989 cuando se aprueba la Convención Internacional sobre los Derechos del Niño, cada Estado parte se comprometió a "proteger al niño contra todas las formas de explotación y abuso sexuales. Con este fin (...) tomarán, en particular, todas las medidas de carácter nacional, bilateral y multilateral que sean necesarias para impedir la explotación del niño en espectáculos o materiales pornográficos" (art. 34 letra c). Esta Convención luego es desarrollada por un Protocolo Facultativo, aprobado por la Asamblea General de Naciones Unidas el 25 de mayo de 2000 y ratificado por Chile el 6 de febrero de 2003, relativo a la venta de niños, la prostitución infantil y la utilización de los niños en la pornografía. En él se declara que todo Estado parte deberá sancionar penalmente "la producción, distribución, divulgación, importación, exportación, oferta, venta o posesión, con los fines antes señalados, de pornografía infantil, en el sentido en que se define el artículo 2" (art. $3^{\circ}$ apartado $1^{\circ}$ letra c), y en esa disposición -art. $2^{\circ}$ letra c- se estipula la definición aplicable a los efectos del Protocolo:

"Por pornografía infantil se entiende toda representación, por cualquier medio, de un niño dedicado a actividades sexuales explícitas, reales o simuladas, o toda representación de las partes genitales de un niño con fines primordialmente sexuales."

Existen otras definiciones que son más o menos similares en diversos instrumentos internacionales y nacionales, como los siguientes:

a) Recomendación 16 del Comité de Ministros del Consejo de Europa ${ }^{11}$ de 31 de octubre de 2001 , artículo $2^{\circ}$ letra c, circunscribe el término a:

"Todo material que muestre bien a un menor desarrollando una conducta sexual explícita, bien a una persona que aparentemente sea un menor desarrollando una conducta sexual explícita o bien represente imágenes realistas de un menor desarrollando una conducta sexual explícita”.

b) Convenio sobre Ciberdelincuencia, aprobado por el Consejo de Europa en Budapest el 23 de noviembre de 2001, ${ }^{12}$ artículo 9.2, estipula que la pornografía infantil comprende:

"todo material pornográfico que contenga la representación visual de:

a. un menor adoptando un comportamiento sexualmente explícito;

b. una persona que parezca un menor adoptando un comportamiento sexualmente explícito;

considera que niño es "todo ser humano menor de dieciocho años de edad, salvo que, en virtud de la ley que le sea aplicable, haya alcanzado antes la mayoría de edad", así como la de pornografía infantil del Protocolo Facultativo, que alude a conductas relativas a niños (art. $2^{\circ}$ letra c), es técnicamente correcto hablar de pornografía infantil siempre que estemos ante menores de dieciocho años. Así MOLINA CANTILLANA, Delitos de pornografía infantil, cit. nota $\mathrm{n}^{\circ} 8$, p. 64, n. 58.

${ }^{11}$ Anteriormente el Consejo de Europa definía la pornografía infantil como "cualquier material audiovisual que utiliza niños en un contexto sexual", Recomendación $\mathrm{N}^{\circ} \mathrm{R}$ (91) 11, de 9 de septiembre de 1991 e Informe del Comité Europeo de Problemas Delictivos (1993), cit. por MORALES PRATS, Fermín, "Pornografía infantil e internet", Ponencia presentada en las Jornadas de Responsabilidad Civil y Penal de los Prestadores de Servicios en Internet, organizadas por la UOC y el Ilustre Colegio de Abogados de Barcelona, Barcelona, 22-23 de noviembre de 2001, p. 1. Disponible en http://www.uoc.edu/in3/dt/20056/20056.pdf

12 Disponible en http://www.coe.int/t/dghl/cooperation/economiccrime/cybercrime/Documents/ Convention\%20and\%20protocol/ETS_185_spanish.PDF 
OSSANDÓN, María Magdalena. "La técnica de las definiciones en la ley penal: Análisis de la definición de "material pornográfico en cuya elaboración hubieren sido utilizados menores de dieciocho años".

c. imágenes realistas que representen a un menor adoptando un comportamiento sexualmente explícito".

c) Directiva 2011/92/UE del Parlamento Europeo y del Consejo de 13 de diciembre de 2011 relativa a la lucha contra los abusos sexuales y la explotación sexual de los menores y la pornografía infantil y por la que se sustituye la Decisión marco 2004/68/JAI del Consejo, ${ }^{13}$ en su artículo 2 letra c define pornografía infantil como:

i) todo material que represente de manera visual a un menor participando en una conducta sexualmente explícita real o simulada,

ii) toda representación de los órganos sexuales de un menor con fines principalmente sexuales,

iii) todo material que represente de forma visual a una persona que parezca ser un menor participando en una conducta sexualmente explícita real o simulada o cualquier representación de los órganos sexuales de una persona que parezca ser un menor, con fines principalmente sexuales, $o$

iv) imágenes realistas de un menor participando en una conducta sexualmente explícita o imágenes realistas de los órganos sexuales de un menor, con fines principalmente sexuales;

d) Declaración de Río de Janeiro, del Tercer Congreso Mundial contra la Explotación Sexual de Niños, Niñas y Adolescentes, de 28 de noviembre de 2008, apartado II sobre "Formas de explotación sexual y sus nuevos escenarios", alude a la necesidad de criminalizar la producción, distribución, recepción y posesión intencional de pornografía infantil:

"incluyendo imágenes virtuales y la representación de niños, niñas y adolescentes con fines de explotación sexual".

e) U.S. Code, Título $18 \S 2256$ (8), ${ }^{14}$ que entre varias definiciones incluye la de child pornography, que significa:

"cualquier representación visual, incluyendo cualquier fotografía, película, video, dibujos o imagen generada por computador, fabricados o producidos por medios electrónicos, mecánicos o de otro tipo, de una conducta sexualmente explícita, cuando:

a) la producción de tal representación visual implica el uso de un menor participando en una conducta sexualmente explícita;

\footnotetext{
${ }^{13}$ En dicha Decisión Marco se definía la pornografía infantil como "cualquier material pornográfico que describa o represente de manera visual: i) a un niño real practicando o participando en una conducta sexualmente explícita, incluida la exhibición lasciva de los genitales o la zona púbica de un niño, o ii) a una persona real que parezca ser un niño practicando o participando en la conducta mencionada en el inciso i), o iii) imágenes realistas de un niño inexistente practicando o participando en la conducta mencionada en el inciso i)".

${ }^{14}$ Sobre la evolución y discusiones generadas a propósito de este concepto, vid. OXMAN, Nicolás, “Aspectos político-criminales y criminológicos de la criminalización de la posesión de pornografía infantil en Estados Unidos de Norteamérica", Polít. crim. Vol. 6, $\mathrm{N}^{\mathrm{o}} 12$ (2011), A2, pp. 252-294, pp. 273-276, en http://www.politicacriminal.cl/Vol_06/n_12/Vol6N12A2.pdf [visitado el 05.01.2014]
} 


\section{Polít. crim. Vol. 9, No 18 (Diciembre 2014), Art. 1, pp. 279-337. [http://www.politicacriminal.cl/Vol_09/n_18/Vol9N18A1.pdf]}

b) tal representación visual es una imagen digital, computacional o generada por computador, que es o se confunde con la de un menor participando en una conducta sexualmente explícita, o

c) como representación visual ha sido creada, adaptada o modificada para mostrar que un menor identificable está participando en una conducta sexualmente explícita”.

f) Código penal colombiano, art. 218, sanciona una serie de conductas relacionadas con la pornografía con personas menores de 18 años, pero al hacerlo se refiere únicamente ${ }^{15} \mathrm{a}$ :

"representaciones reales de actividad sexual que involucre persona menor de 18 años de edad".

De todas estas definiciones la contenida en el Protocolo Facultativo ha sido reiterada en otras instancias internacionales, ${ }^{16}$ incluyendo alguna más reciente del Consejo de Europa ${ }^{17}$

${ }^{15}$ Con todo, en ese país se ha publicado un documento, del INSTITUTO COLOMBIANO DE BIENESTAR FAMILIAR, Criterios de clasificación de páginas en internet con contenidos de pornografía infantil, Imprenta Nacional de Colombia. Ministerio de la Protección Social - Ministerio de Comunicaciones Instituto Colombiano de Bienestar Familiar - ICBF Fiscalía General de la Nación - Defensoría del Pueblo Instituto Nacional de Medicina Legal y Ciencias Forenses Departamento Administrativo de Seguridad - DAS - Policía Nacional - DIJIN - Fondo de Población de las Naciones Unidas - UNFPA, 2004, p. 25, que expresa:

"La pornografía infantil está referida a toda representación visual, auditiva o de texto, incluidos dibujos animados o juegos de video, que de manera real o simulada, explícita o sugerida, involucre la participación de un sujeto calificado: niños, niñas o personas que aparentan ser niños o niñas, a cualquier título (protagonistas, partícipes o espectadores), con la participación o no de adultos, en el desarrollo de una conducta de exhibición, representación, descripción, proyección, colección, creación o uso de:

1. Acceso carnal. Se entenderá por acceso carnal la penetración del miembro viril por vía anal, vaginal u oral, así como la penetración vaginal o anal de cualquier otra parte del cuerpo humano u otro objeto.

2. Actos sexuales abusivos, entendidos como toda acción sexual diversa del acceso carnal.

3. Representación de las partes genitales de un niño o niña con fines sexuales, o en un contexto de página pornográfica o como parte de una escena sexual (conjunto de acciones de índole sexual).

4. Escenas sexuales con animales o figuras fantasiosas o imágenes o figuras virtuales, digitalizadas o creadas.

5. Escenas sexuales que involucren violencia, tortura, sometimiento, o similares.

6. Niños, niñas o personas con apariencia de niños o niñas, que aparecen en contextos utilizados por adultos y prohibidos para niños por la ley. Ej: bares, prostíbulos y que se encuentren en el contexto de una página pornográfica o como parte de una escena sexual

7. Que el contexto de la página o escena incluya o sugiera expresa o sutilmente, reserva, secreto o confidencialidad o invitación a ser parte o miembro activo de esa comunidad.

8. Niño o niña utilizando artículos o juguetes sexuales en un contexto de página pornográfica o como parte de una escena sexual.

9. Representaciones simbólicas referidas a objetos de uso infantil tales como juguetes, ropa o accesorios.

10. Que el contexto de la página o escena incluya oferta o posibilidad de compraventa del material, contraprestación, pago por ver, o solicitudes de carácter sexual”.

${ }^{16}$ Por ejemplo, así se estipula en la Reunión de Seguimiento del II Congreso Mundial contra la Explotación Sexual Comercial de Niños, Niñas y Adolescentes -América Latina y el Caribe-, San José, Costa Rica, de mayo 2004, al considerar pornográfico todo material en el que se utilice a una persona menor de dieciocho años o su imagen en actividades sexuales explícitas, reales o simuladas o la representación de sus partes genitales con fines primordialmente sexuales o eróticos.

${ }^{17} \mathrm{El}$ art. 20.2 de la Convención del Consejo de Europa para la protección de la infancia contra la explotación y los abusos sexuales, Lanzarote, del 25 de octubre de 2007 establece que "A los efectos del presente artículo, por el término pornografía infantil se entenderá cualquier material que represente de manera visual a un niño 
OSSANDÓN, María Magdalena. "La técnica de las definiciones en la ley penal:

Análisis de la definición de "material pornográfico en cuya elaboración hubieren sido utilizados menores de dieciocho años".

y también ha sido adoptada casi de modo literal por algunos ordenamientos jurídicos, ${ }^{18}$ entre ellos el nuestro. Con todo, la tendencia legislativa sigue siendo la de sancionar penalmente las conductas relacionadas con el material pornográfico infantil sin ofrecer una definición expresa de lo que se entiende por tal. ${ }^{19}$

\section{Incorporación de la definición en el derecho chileno}

En Chile la legislación ha evolucionado de modo paralelo a la regulación internacional, a través de vacilantes y superpuestas modificaciones:

a) Ley $N^{o}$ 19.617, de 12 de julio de 1999: supuso la tipificación del delito de utilización de menores de doce años en la producción de material pornográfico, ${ }^{20}$ pero sin incluir una definición de lo que se entendía por pornografía.

b) Ley $N^{o}$ 19.846, de 4 de enero de 2003, sobre calificación de la producción cinematográfica: incorpora en su propio texto, fuera del Código penal, una figura relativa a la producción y tráfico de material pornográfico infantil, ${ }^{21}$ así como un concepto genérico de pornografía. En efecto, en su artículo $2^{\circ}$ establece que "Para los efectos de esta ley se entenderá por: d) Contenido pornográfico: la exposición abusiva o grosera de la sexualidad o la exposición de imágenes obscenas, con interacciones sexuales más o menos continuas que, manifestadas en un plano estrictamente genital, constituyen su principal fin".

en una conducta sexualmente explícita real o simulada o cualquier descripción o representación de los órganos sexuales de un niño con fines primordialmente sexuales".

${ }^{18}$ Es el caso de Italia, que en el art. 600-ter inciso final CP estipula: "Para efectos de este artículo por pornografía infantil se entiende toda representación, por cualquier medio, de un menor de dieciocho años involucrado en actividades sexuales explícitas, reales o simuladas, o toda representación de los órganos sexuales de un menor de dieciocho años de edad con fines sexuales", disposición introducida por la Legge 01.10.2012 $\mathrm{n}^{\circ}$ 172, G.U. 08.10.2012, a través de la cual se ratificaba la Convención de Lanzarote que acabamos de mencionar. Con todo, el art. 600-quater 1. amplía en la práctica el concepto a los supuestos en que se representen imágenes virtuales realizadas utilizando imágenes de menores o partes de ellos, evento en el cual se aplican las disposiciones que sancionan los diversos comportamientos relacionados con la pornografía infantil, pero con una pena disminuida en un tercio.

También Argentina usa la definición del Protocolo, el art. 128 CP la incorpora en la descripción típica que establece que: "Será reprimido con prisión de seis (6) meses a cuatro (4) años el que produjere, financiare, ofreciere, comerciare, publicare, facilitare, divulgare o distribuyere, por cualquier medio, toda representación de un menor de dieciocho (18) años dedicado a actividades sexuales explícitas o toda representación de sus partes genitales con fines predominantemente sexuales, al igual que el que organizare espectáculos en vivo de representaciones sexuales explícitas en que participaren dichos menores".

${ }^{19}$ Como ocurre en las legislaciones penales de Perú, Brasil, Portugal, Alemania y España, por ejemplo.

${ }^{20}$ El inciso 2 del art. 366 quáter CP sancionaba con reclusión menor en cualquiera de sus grados al que "empleare un menor de doce años en la producción de material pornográfico".

${ }^{21}$ Junto con derogar el inciso 2 del art. 366 quáter CP, incluye entre sus disposiciones lo siguiente: "Artículo 30.- El que participe en la producción de material pornográfico, en cualquier soporte, en cuya elaboración hayan sido utilizados menores de 18 años, será sancionado con reclusión menor en sus grados medio a máximo. / El que comercialice, importe, distribuya o exhiba material pornográfico, en cualquier soporte, en cuya elaboración hayan sido empleados menores de 18 años, será sancionado con la pena de reclusión menor en sus grados mínimo a medio". 


\section{Polít. crim. Vol. 9, No 18 (Diciembre 2014), Art. 1, pp. 279-337. \\ [http://www.politicacriminal.cl/Vol_09/n_18/Vol9N18A1.pdf]}

c) Ley $N^{o}$ 19.927, de 14 de enero de 2004: al mismo tiempo que se dicta la normativa recién mencionada, se tramitaba en el Congreso otra ley sobre delitos de pornografía infantil, ${ }^{22}$ que terminó por reconducir al Código penal -con algunas modificaciones-, los delitos de producción, tráfico y tenencia de material pornográfico infantil. ${ }^{23}$ Además, asumiendo que nuestras normas "habían demostrado contener importantes vacíos y ser insuficientes e imperfectas para enfrentar adecuadamente el problema de la pornografía infantil", entre otros motivos, por carecer de un concepto de pornografía infantil, ${ }^{24}$ incluye también su definición legal en el art. 366 quinquies inciso segundo en los siguientes términos:

"Para los efectos de este artículo y del artículo 374 bis, se entenderá por material pornográfico en cuya elaboración hubieren sido utilizados menores de dieciocho años, toda representación de éstos dedicados a actividades sexuales explícitas, reales o simuladas, o toda representación de sus partes genitales con fines primordialmente sexuales".

Al hacerlo, el objetivo explícito -al menos en la moción parlamentaria que dio inicio a la tramitación de esa normativa- fue que la definición permitiría "incluir supuestos fácticos que han sido incorporados en la legislación comparada, tales como las imágenes con niños virtuales. Es necesario también que el concepto de pornografía infantil abarque todas formas [sic] en que se puede cometer el delito, para evitar que de otro modo queden impunes". ${ }^{25}$ La redacción tuvo como base la definición del Protocolo Facultativo, preferida por sobre la contemplada en la letra d) del artículo $2^{\circ}$ de la Ley $\mathrm{N}^{\circ}$ $19.846 .^{26}$

Coetáneamente se redactaba el Anteproyecto de Código Penal Chileno de 2005, elaborado por la Comisión Foro Penal, en el que se desestimó la necesidad de incorporar una definición de este tipo, "entendiendo que ella es propia de la labor jurisprudencial y (...) puede deducirse con seguridad de lo dispuesto en la Ley de Calificación Cinematográfica". ${ }^{27}$

d) Ley $N^{\circ}$ 20.526, de 13 de agosto de 2011: modifica la definición agregando al final la hipótesis de "toda representación de dichos menores en que se emplee su voz o imagen

\footnotetext{
${ }^{22}$ Originada en una moción parlamentaria presentada el 10 de abril de 2002, boletín No 2906-07.

${ }^{23}$ En dos disposiciones, el artículo 366 quinquies.- "El que participare en la producción de material pornográfico, cualquiera sea su soporte, en cuya elaboración hubieren sido utilizados menores de dieciocho años, será sancionado con presidio menor en su grado máximo"; y el artículo 374 bis.- "El que comercialice, importe, exporte, distribuya, difunda o exhiba material pornográfico, cualquiera sea su soporte, en cuya elaboración hayan sido utilizados menores de dieciocho años, será sancionado con la pena de presidio menor en su grado medio a máximo. / El que maliciosamente adquiera o almacene material pornográfico, cualquiera sea su soporte, en cuya elaboración hayan sido utilizados menores de dieciocho años, será castigado con presidio menor en su grado medio".

${ }^{24}$ Así se planteó en la moción parlamentaria que dio inicio a la tramitación de la normativa, vid. Historia de la Ley $N^{o}$ 19.927, Biblioteca del Congreso Nacional, 2004, p. 5, disponible en http://www.leychile.cl

${ }^{25}$ Historia de la Ley $N^{\circ} 19.927$, cit. nota $\mathrm{n}^{\circ} 24$, p. 7.

${ }^{26}$ Se indicó expresamente en el Primer informe complementario de la Comisión Constitución y Justicia, Historia de la Ley $N^{o}$ 19.927, cit. nota $\mathrm{n}^{\circ}$ 24, p. 244.

27 "Materiales de Discusión presentados a la Comisión Foro Penal, Parte Especial", Polít. crim. Vol. 1, No 1, (2006), D3, p. 1-269, p. 188, n. 295.
} 
OSSANDÓN, María Magdalena. "La técnica de las definiciones en la ley penal: Análisis de la definición de "material pornográfico en cuya elaboración hubieren sido utilizados menores de dieciocho años".

con los mismos fines", con la finalidad de abarcar también una variedad de pornografía virtual conocida como pseudopornografía, "donde se emplea la imagen o voz captada de un menor y por medio de manipulaciones virtuales se la incorpora en una producción pornográfica, de modo de hacer parecer que el menor efectivamente participó en las acciones sexuales que se muestran". ${ }^{2}$

De este modo ha quedado fijado el texto actualmente vigente, en los siguientes términos:

"Para los efectos de este artículo y del artículo 374 bis, se entenderá por material pornográfico en cuya elaboración hubieren sido utilizados menores de dieciocho años, toda representación de éstos dedicados a actividades sexuales explícitas, reales o simuladas, o toda representación de sus partes genitales con fines primordialmente sexuales o toda representación de dichos menores en que se emplee su voz o imagen, con los mismos fines."

Antes de ir a las particularidades de esta disposición, haremos un breve repaso sobre lo que se entiende por una definición legal y sus características más relevantes.

\section{Definiciones legales. Concepto y funciones}

En la teoría de la definición ha existido una evolución marcada por el paso de una concepción de la misma como develadora de la esencia de lo definido, al reconocimiento de la tarea definitoria como operación que tiene lugar a nivel meramente linguiístico. ${ }^{29}$ En efecto, en la tradición escolástica basada en la doctrina aristotélica, las definiciones se conciben como una proposición verdadera o falsa que revela la naturaleza íntima de un objeto o fenómeno al que se hace referencia: estas son las definiciones reales. Ellas se distinguen de las definiciones nominales que son las que recaen sobre un signo linguiístico para atribuirle un significado.

Precisamente, este último sentido es el que corresponde para las definiciones incluidas en una ley, que pueden ser consideradas como una estipulación o convención acerca del uso de un término, por la cual se atribuye, explica o precisa su significado en atención a ese uso; un enunciado incluido por el legislador para establecer o clarificar el significado de algún término por él utilizado. ${ }^{30}$ La definición sirve, entonces, para orientar o hacer explícito el

\footnotetext{
${ }^{28}$ Moción parlamentaria, en Historia de la Ley $N^{o}$ 20.526, Biblioteca del Congreso Nacional, 2011, p. 6. Se excluirían, en consecuencia, otras formas de pornografía virtual, como la que consiste en la creación por medios informáticos -sin emplear la imagen o voz de una persona real- de imágenes o sonidos pornográficos (también conocida como pornografía virtual, sin más); y la pornografía técnica, en la que se alteran imágenes de adultos, con la finalidad de que parezcan menores de edad.

${ }^{29}$ Actualmente se tiende a hablar de definición en este último sentido, propio de las definiciones nominales, por los innumerables significados atribuibles a las definiciones reales, cfr. PARLATO, Maria Concetta, Le definizioni legislative nel sistema penale tributario, Bari: Cacucci Editore, 2012, p. 23; en el mismo sentido, CAPELLA, Juan Ramón, "Notas sobre la definición legal", Anuario de filosofía del derecho, No 10 (1963), pp. 37-50, pp. 37-38 e ITURRALDE SESMA, Victoria, Lenguaje legal y sistema jurídico, Madrid: Tecnos, 1989 , p. 37.

30 TARELLO, Giovanni, L’interpretazione della legge, Milano: Giuffrè, 1980, p. 154. Al explicar en qué consiste una definición legal se suele poner el acento en su carácter atributivo de significado, vgr.
} 


\section{Polít. crim. Vol. 9, No 18 (Diciembre 2014), Art. 1, pp. 279-337. \\ [http://www.politicacriminal.cl/Vol_09/n_18/Vol9N18A1.pdf]}

principio que guía el uso de una palabra, sin que ello signifique buscar en ella la esencia inalterable de una realidad. $^{31}$

Etimológicamente el término de-finitio alude al establecimiento de límites y, en este sentido, se puede pensar que las definiciones pueden servir para acotar y limitar un ámbito conceptual, dar mayor precisión a los términos utilizados por la ley y así colaborar a que el Derecho penal sea más restringido. Sin embargo, también desde una perspectiva etimológica la definición puede ser relacionada, en diverso sentido, con la idea de "proponerse fines". En la teoría de la legislación, por lo demás, se le han atribuido funciones bien diversas: la de servir como un modo de enseñar el derecho al pueblo (función pedagógica), ${ }^{32}$ la de permitir el desarrollo de los Código como universos jurídicos autónomos (función sistemática), ${ }^{33}$ la de evitar repeticiones y abreviar el texto legal (función de economía), ${ }^{34}$ etc.

Con todo, en la actualidad advertimos que la opinión predominante es que ellas tienen una doble finalidad. Primero, la de lograr una mayor certeza, pues al definir un término se

GUASTINI, Riccardo, "Redazione e interpretazione dei documenti normativi”, en: BARTOLE (a cura di), Lezioni di tecnica legislativa, Padova: Cedam, 1988, pp. 37-117, p. 83; BELVEDERE, Andrea, "Note in tema di definizioni legislative penalistiche", en: CADOPPI, Alberto (coord.), Omnis definitio in iure periculosa? Il problema delle definizioni legali nel Diritto penale, Padova: Cedam, 1996, pp. 109-124, p. 110, quien la caracteriza como una "explícita atribución de significado a una palabra mediante otra palabra" (destacado en el original); y SGARBI, Adrian, "What Is a Good Legislative Definition?”, Beijing Law Review, Vol.4, N¹ (2013), pp. 28-36, p. 28, en: http://www.scirp.org/journal/blr [visitado el 13.12.2013]. Pero como esto no ha de ser, necesariamente, de un modo originario o ex novo -como ocurre, en general, en las definiciones legales-, hemos preferido destacar sus diversas modalidades, como HERNÁNDEZ MARÍN, Rafael, Introducción a la teoría de la norma jurídica, $2^{\mathrm{a}}$ ed., Madrid-Barcelona: Marcial Pons, 2002, p. 301, quien concibe las definiciones como "enunciados que sirven para fijar, aclarar o precisar el sentido de una expresión"; o SÁNCHEZ-OSTIZ GUTIÉRREZ, Pablo, "Relevancia de las definiciones legales en la aplicación del Derecho penal” en: MONTIEL, Juan Pablo (ed.), La crisis del principio de legalidad en el nuevo Derecho penal: ¿decadencia o evolución?, Madrid: Marcial Pons, 2012 p. 210, quien entiende la definición como "una proposición que declara algo desconocido o aclara algo confuso mediante elementos conocidos que se ordenan según el esquema genus proximum y differentia specifica".

31 Cfr. HART, H.L.A., The Concept of Law, I, 3, 2 a ed., Oxford: Oxford University Press, 1994 , p. 14. Precisamente este es el sentido que siempre se ha propuesto para las definiciones en el Derecho anglosajón, de modo que al término definido solo se le debe dar el sentido que le ha asignado la definición para la aplicación de la ley en que se inserta. La tradición civil francesa y alemana, en cambio, apuntaba a proponer definiciones reales que pretendían mostrar una realidad preexistente, abarcándola en su contenido esencial; sobre esto LASSERRE-KIESOW, La technique législative, cit. nota $\mathrm{n}^{\mathrm{o}}$ 1, pp. 158-159. Una tradición recibida también en nuestro medio, vgr. TAPIA VALDÉS, Jorge, La técnica legislativa, Santiago: Editorial Jurídica de Chile, 1960, p. 76, quien afirma que la definición tiene por objeto conceptuar una palabra o cosa, exponer los caracteres genéricos y diferenciales y trazar los contornos de una institución, y fijar su esencia, entre otras funciones.

32 Así VON PLANITZ, "Über Legaldefinitionen", in Zeitschrift für deutsches Recht un deutsche Rechtswissenschaft, 1847, p. 496, y BENTHAM, Jeremy, Traité de législation civile et pénale, t. I, Paris, Bossange, 1802, p. 368, citados por LASSERRE-KIESOW, La technique législative, cit. nota $\mathrm{n}^{\circ} 1$, p. 157, n. 34 con ulteriores referencias.

${ }^{33}$ Explica Portalis que la autonomía del Código demanda la necesidad de las definiciones: "puisqu'on rèdige un Code destiné à remplacer le droit écrit et les coutumes, on ne peut se dispenser de definir", en: FENET, Travaux préparatoires du Code Civil, t. XII, p. 262, cit. por LASSERRE-KIESOW, La technique législative, cit. nota $\mathrm{n}^{\mathrm{o}} 1$, p. 158 , n. 36.

${ }^{34}$ Lo destaca TAPIA VALDÉS, La técnica legislativa, cit. nota ${ }^{\circ} 31$, p. 76. 
OSSANDÓN, María Magdalena. "La técnica de las definiciones en la ley penal: Análisis de la definición de "material pornográfico en cuya elaboración hubieren sido utilizados menores de dieciocho años".

delimitan sus contornos y se reduce, así, la vaguedad de que puede adolecer la expresión definida, al mismo tiempo que se elimina su eventual ambigüedad. ${ }^{35} \mathrm{Si}$ sirven para precisar el contenido de la ley entonces en el ámbito penal aparecen como un buen mecanismo para limitar el ejercicio del ius puniendi. Y segundo, la de configurar un mecanismo de equilibrio entre los diferentes órganos y poderes que intervienen en el sistema jurídico, ${ }^{36}$ pues al definir un término se reducen las posibilidades de interpretación y se disminuye la discrecionalidad de los operadores en la referida atribución de significado, ${ }^{37}$ garantizando una mayor igualdad en la aplicación de la ley. ${ }^{38}$ Las definiciones legales, de este modo, pueden llegar a invadir un terreno típicamente dominado por la jurisprudencia y la doctrina, ${ }^{39}$ para reencauzar este ámbito de decisiones a las manos del legislador, lo que puede considerarse especialmente favorable para un mejor cumplimiento de las exigencias de legalidad.

De este modo, las definiciones podrían garantizar una mayor seguridad jurídica y uniformidad en la aplicación del Derecho, reduciendo el campo de las discusiones y las arbitrariedades, lo que las convertiría en una técnica muy recomendable en materia penal. ${ }^{40}$

${ }^{35}$ Generalmente se presentan como una técnica legislativa que cumple una finalidad garantística al permitir una mayor determinación de la ley penal, cfr. los trabajos contenidos en: CADOPPI, Alberto (coord.), Omnis definitio in iure periculosa? Il problema delle definizioni legali nel Diritto penale, Padova: Cedam, 1996: BRICOLA, Franco, "Le definizioni normative nell'esperienza dei codici penali contemporanei e nel progetto di delega italiano", pp. 175-190; MORALES PRATS, Fermín, "Omnis definitio in iure periculosa? El problema de las definiciones en el Código penal español y en el Proyecto de Código penal de 1992”, pp. 275331; y PALAZZO, Francesco, "Sulle funzioni delle norme definitorie", pp. 381-390. En el mismo sentido PARLATO, Le definizioni legislative, cit. nota n 29, pp. 35, 38 y 40, y SGARBI, "Legislative Definition", cit. nota $\mathrm{n}^{\mathrm{o}} 30$, p. 34.

${ }^{36}$ En este sentido, MORALES PRATS, "Omnis definitio", cit. nota no 35, p. 328; PALAZZO, "Sulle funzioni”, cit. nota $n^{\circ} 35$, p. 382; PARLATO, Le definizioni legislative, cit. nota $n^{\circ} 29$, p. 37 y SEMERARO, Pietro, "Definizioni e funzione di garanzia della legge penale, en CADOPPI (coord.), Omnis definitio in iure periculosa? Il problema delle definizioni legali nel Diritto penale, Padova: Cedam, 1996, pp. 495-498, p. 495.

${ }^{37}$ VIDAL OLIVARES, Álvaro, "La técnica legislativa y la interpretación de la ley", en: OELCKERS, Osvaldo et. al., La técnica legislativa ante la elaboración de la ley, Valparaíso, CEAL, 1998, pp. 323-349, p. 339.

${ }^{38}$ FRISCH, Wolfgang, "Le definizioni legali nel diritto penale tedesco", en: CADOPPI, Alberto (coord.), Omnis definitio in iure periculosa? Il problema delle definizioni legali nel Diritto penale, Padova: Cedam, 1996, pp. 191-238, p. 229.

${ }^{39}$ Cfr. FRISCH, "Le definizioni legali", cit. nota no 38, p. 192.

${ }^{40} \mathrm{Al}$ extremo de que se ha sostenido, por autores de la talla de Marinucci y Dolcini, que "è opportuno e doveroso che il legislatore penale, suprattutto quando faccia un uso ricorrente di termini suscettibili di molteplici interpretazioni, ne fornisca una definizione. Si trata di una técnica già ampiamente collaudata nella vigente legislazione italiana, della quale si deve se mai auspicare un uso più metodico ed effettivamente rispondente agli obiettivi di precisione. L'adagio, omnis definitio in iure periculosa debe essere relegato tra le anticaglie, come espressione di un diritto penale sordo alle esigenze di legalità", MARINUCCI, Giorgio; DOLCINI, Emilio, Corso di Diritto penale, I, $3^{\mathrm{a}}$ ed., Milano: Giuffrè, 2001, p. 149; aunque más adelante reconocen que en ocasiones el recurso a las definiciones puede que no consiga la finalidad perseguida, de dar mayor precisión a la ley, pero entonces no sería un problema de la técnica, de por sí funcional para ello, sino del mal uso que se ha hecho de ella (p. 130-131). En el mismo sentido CADOPPI, Alberto, Il problema delle definizioni legali nel Diritto penale. Presentazione, en: CADOPPI, Alberto (coord.), Omnis definitio in iure periculosa? Il problema delle definizioni legali nel Diritto penale, Padova: Cedam, 1996, p. 17, entiende que el deber de usar definiciones en Derecho penal "se presume salvo prueba en contrario". PARLATO, Le definizioni legislative, cit. nota $\mathrm{n}^{\text {o } 29}$, pp. 38-39 distingue según si se trata de la parte especial, en que serían altamente recomendables, y la parte general, en que pueden impedir el desarrollo evolutivo de la 


\section{Polít. crim. Vol. 9, No 18 (Diciembre 2014), Art. 1, pp. 279-337. \\ [http://www.politicacriminal.cl/Vol_09/n_18/Vol9N18A1.pdf]}

Pero, según veremos, ello no siempre ocurre así, pues la definición no constituye más que un medio, "y, como todos los medios, será conveniente en la medida en que cumple con los requisitos técnicos que debe reunir y aporta las soluciones que los objetivos propuestos le fijan". ${ }^{41}$ De lo contrario se puede convertir en fuente de nuevos problemas de interpretación y generar desigualdad en su aplicación, para acabar dándole razón a la máxima según la cual omnis definitio in iure periculosa est. ${ }^{42}$

\section{Efectividad o valor vinculante de las definiciones legales}

Una cuestión decisiva respecto de las definiciones legales es la de su efectividad, esto es, su real capacidad para incidir en la aplicación del Derecho. La discusión se ha desarrollado fundamentalmente en el campo del Derecho civil, y, aunque existieron fuertes discrepancias en otras épocas, ha terminado decantándose por la afirmación de ese carácter vinculante. ${ }^{43}$ En general, se entiende que el intérprete del Derecho está sujeto a las definiciones tanto como lo está respecto de cualquier otro enunciado normativo; ${ }^{44}$ y con mayor razón en el sector penal, en razón de la vigencia estricta del principio de legalidad.

Pero admitido ese valor vinculante, "aun los jueces sólo están obligados a usar las definiciones legales, cuando éstas han sido efectivamente usadas por el propio legislador,

interpretación. Nosotros ya nos hemos pronunciado por un uso únicamente excepcional de este recurso legislativo, OSSANDÓN WIDOW, M. Magdalena, La formulación de tipos penales, Santiago: Editorial Jurídica de Chile, 2009, p. 265.

${ }^{41}$ MARTINO, Antonio Anselmo, "Definiciones legales", en: WARAT, Luis Alberto; MARTINO, Antonio Anselmo, Lenguaje y definición jurídica, Buenos Aires: Cooperadora de Derecho y Ciencias Sociales, 1973, pp. 59-90, p. 88.

${ }^{42}$ Omnis definitio in iure civile periculosa est: rarum [parum] est enim ut non subverti possit, JAVOLENTO, Epist., lib. I, en: Digesto lib. 50, tít. 17, n. 202; significa que "toda definición en Derecho (civil) es peligrosa, porque es difícil que no necesite ser alterada", según la versión de RODRÍGUEZ DÍEZ, José, "Versión española de las Reglas jurídicas del Corpus de Derecho Canónico", Anuario Jurídico y Económico Escurialense, XLI (2008), pp. 287-312, p. 291.

${ }^{43}$ Una breve exposición de las posiciones y su evolución en ITURRALDE SESMA, Lenguaje legal, cit. nota $\mathrm{n}^{\mathrm{o}} 29$, pp. 59-60 y JORI, Mario, "Definizioni legislativa e pragmatica giuridica", en: CADOPPI, Alberto (coord.), Omnis definitio in iure periculosa? Il problema delle definizioni legali nel Diritto penale, Padova: Cedam, 1996, pp. 55-93, pp. 63-66. Afirman la fuerza vinculante de las definiciones, entre otros, LARENZ, Karl, Metodología de la Ciencia del Derecho, trad.: RODRÍGUEZ MOLINERO, Marcelino, Barcelona: Ariel, 1994, pp. 64 y 250; ROSS, Alf, "La definizione nel linguaggio giuridico", en: SCARPELLI (a cura di), Diritto $e$ analisi del linguaggio, Milano: Ed. Comunita, 1976, pp. 199-214, pp. 213-214 y SCARPELLI, Uberto "La definizione nel diritto", en: SCARPELLI (a cura di), Diritto e analisi del linguaggio, Milano: Ed. Comunita, 1976, pp. 183-197, pp. 192-197. En contra CAPELLA, "Notas", cit. nota n 29, p. 46.

${ }^{44}$ Para Alchourrón y Bulygin, aunque exista una obligación de respetar los términos de la definición legal, no puede afirmarse que ellas tengan carácter normativo. Porque "la definición sirve para identificar ciertas normas y como la identificación de las normas es condición necesaria para su aplicación, cabe formular la regla técnica según la cual, el que quiere aplicar o usar las normas, debe identificarlas y para identificarlas debe usar la definición del legislador. Si no la usa, identificará otra norma y no la que el legislador dictó", Sólo el juez está obligado a aplicar las normas jurídicas y para eso debe identificarlas, pero su obligación de usar las definiciones no surge propiamente de la definición sino de otras normas sustantivas. ALCHOURRÓN, Carlos; BULYGIN, Eugenio, "Definiciones y normas", en: BULYGIN, Eugenio et al. (comps.), El lenguaje del Derecho. Homenaje a Genaro Carrió, Buenos Aires: Abeledo Perrot, 1983, pp. 1142, p. 24. En el mismo sentido HERNÁNDEZ MARÍN, Introducción, cit. nota no 30, p. 302, las considera enunciados jurídicos cualificatorios, diferentes de los enunciados asertivos (no son verdaderas ni falsas), y de los prescriptivos (no son eficaces o ineficaces, no pueden ser cumplidas o violadas). Le asigna connotación normativa, en cambio, BRICOLA, "Le definizioni normative", cit. nota no 35, p. 179. 
OSSANDÓN, María Magdalena. "La técnica de las definiciones en la ley penal: Análisis de la definición de "material pornográfico en cuya elaboración hubieren sido utilizados menores de dieciocho años".

pues sólo entonces su uso es condición necesaria para la identificación de la norma" ${ }^{45}$ En la práctica, una definición no ofrece garantía de que el término respectivo haya de ser siempre entendido en el sentido fijado, porque tampoco es inusual que el legislador, habiendo dicho que va a usar un término en un determinado sentido, no lo haga así realmente. En consecuencia, se precisarían sólo especiales razones para demostrar que en una determinada descripción típica el término tiene un significado diferente, para poder apartarse de la definición legalmente establecida. ${ }^{46}$ Razones que en el ámbito penal tienen que estar bien fundamentadas en la propia ley, para que este procedimiento no signifique vulnerar el principio de legalidad.

Por otra parte, incluso la definición aparentemente más perfecta y precisa se presenta ella misma como objeto de interpretación ${ }^{47}$ y puede provocar incertidumbre, especialmente cuando en su aplicación práctica genera soluciones inadecuadas o, en el caso concreto, parece no haber tomado en cuenta ciertas características o situaciones. ${ }^{48}$ De este modo el juez puede llegar a modificar una definición a través de su interpretación, especialmente cuando ella ha sido redactada de modo deficiente.

\section{Empleo de definiciones legales en el ámbito penal}

En el contexto histórico-evolutivo del Derecho, es posible advertir que esta técnica legal se ha utilizado para la resolución de múltiples y variadas cuestiones de índole dogmática o político-criminal, algunas sugeridas por la propia evolución jurisprudencial sobre determinados institutos jurídicos. Es el caso de las definiciones de conceptos fundamentales de la parte general, como delito, dolo, causalidad, tentativa, autor, delito continuado, etc. Pero resulta cuestionable su incorporación en la ley, pues ellas suelen tener un marcado carácter doctrinal y hacerlo significaría optar por una posición teórica en desmedro de otras posibles, estorbando el desarrollo de la ciencia dogmático-penal. ${ }^{49}$

45 ALCHOURRÓN/BULYGIN, "Definiciones y normas", cit. nota no 44, p. 27. Similar, en el ámbito civil, LASSERRE-KIESOW, La technique législative, cit. nota $\mathrm{n}^{\mathrm{o}}$ 1, p. 308: el juez solo queda absolutamente vinculado a la definición que es perfecta, en el sentido de que refleje el pensamiento del legislador y sea también precisa; el problema es que aun la más perfecta de las definiciones presenta incertidumbres ligadas al sentido de las palabras en ella utilizadas.

${ }^{46}$ Así, LARENZ, Metodología, cit. nota no 43, p. 318. En sentido similar, FRISCH, "Le definizioni legali”, cit. nota $n^{\circ} 38$, pp. 210-212. Desde este punto de vista no parece tan lejana una posición contraria a la vinculatoriedad de las definiciones legales, como la de ANTOLISEI, Francesco, Manuale di Diritto penale. Parte Generale, 14 ${ }^{\mathrm{a}}$ ed., Milano: Giuffrè, 1997. p. 92, cuando afirma que éstas conforman simples generalizaciones destinadas a facilitar la aplicación de la ley.

${ }^{47}$ NOLL, Peter, "Zur Gesetzestechnik des Entwurfes eines Strafgesetzbuches”, JZ (1963), p. 299, cit. por ORRÙ, Giovanni, "Le definizioni del legislatore e le ridefinizioni della giurisprudenza", en: CADOPPI, Alberto (coord.), Omnis definitio in iure periculosa? Il problema delle definizioni legali nel Diritto penale, Padova: Cedam, 1996, pp. 147-161, p. 156. En el mismo sentido PARLATO, Le definizioni legislative, cit. nota $\mathrm{n}^{\mathrm{o}} 29$, pp. 122-123.

${ }^{48}$ Cfr. LASSERRE-KIESOW, La technique législative, cit. nota ${ }^{\circ}$ 1, p. 314.

${ }^{49}$ La objeción a esta clase de definiciones durante el período de las codificaciones era generalizada; a ellas parece referirse la máxima del Digesto, omnis definitio in iure civile periculosa est. Vid. referencias históricas en LASSERRE-KIESOW, La technique législative, cit. nota $\mathrm{n}^{\mathrm{o}}$ 1, pp. 160-161; en la actualidad, por todos, CADOPPI, Il problema, cit. nota $\mathrm{n}^{\circ} 40$, p. 21, n. 48. 


\section{Polít. crim. Vol. 9, No 18 (Diciembre 2014), Art. 1, pp. 279-337. \\ [http://www.politicacriminal.cl/Vol_09/n_18/Vol9N18A1.pdf]}

Por otra parte y en sentido amplio, también puede considerarse que la descripción típica en sí es una definición de carácter incidental, formulada mientras se está manifestando otro enunciado jurídico. ${ }^{50}$ En efecto, las normas incriminatorias podrían estimarse definitorias en sentido lato, porque al tipificar el legislador pone límites a lo que se considera como acciones ofensivas relevantes penalmente. ${ }^{51}$ Así, homicidio, violación, robo, etc., son términos que el legislador definiría mediante una serie de elementos que constituyen esos nomina iuris ${ }^{52}$ con mayor razón en aquellos supuestos, como los delitos de injurias o calumnia, en que las disposiciones parecen limitarse a definir el término. ${ }^{53}$ Pero en un sentido más estricto, como decía Larenz "el tipo no se define, sino que se describe"; 54 la disposición penal detalla algunos de los elementos del ámbito conceptual, ${ }^{55}$ no con el objeto de declarar o precisar el sentido de un término, sino para establecer la hipótesis de aplicación de la norma secundaria, que se dirige al juez ordenándole que imponga una sanción penal. Por lo tanto, para no generar una ambigüedad respecto del término "definición", consideramos preferible seguir hablando en estos casos de "descripción típica".

La hipótesis que vamos a analizar es diversa a las anteriores, y puede estudiarse como un particular instrumento de técnica legislativa de la parte especial del Derecho penal, ${ }^{56}$ en cuanto se trata de una definición explícita en la que el definiendum, esto es, la expresión que se trata de definir, constituye uno de los componentes utilizados en la descripción de alguna figura típica de la parte especial.

El recurso a esta clase de definiciones no es una técnica muy frecuente, aunque modernamente el legislador tiende a recurrir más a ella. ${ }^{57}$ En nuestro Código penal, podemos mencionar la definición de "armas" en el art. 132, a la que también se remite la disposición que regula la agravante de porte de armas (art. $12 \mathrm{~N}^{\mathrm{o}} 20$ ); la de "funcionario público" en el art. 260 y "funcionario público extranjero" en el art. 251 ter; la de "familia"

\footnotetext{
${ }^{50}$ Así HERNÁNDEZ MARÍN, Introducción, cit. nota no 30, p. 310; una forma de definir que, en todo caso, es criticada por el autor, pues lo deseable es separar unos enunciados de otros (p. 315).

${ }^{51}$ Cfr. BRICOLA, "Le definizioni normative", cit. nota $\mathrm{n}^{\circ} 35$, p. 176; MORALES PRATS, "Omnis definitio",

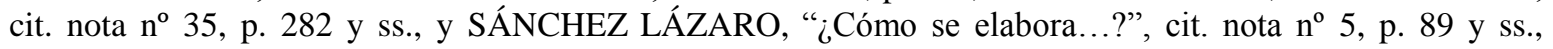
describe como definiciones legales tanto las disposiciones referidas a un instituto de la parte general como a las figuras delictivas de la parte especial.

${ }^{52}$ SÁNCHEZ-OSTIZ, "Relevancia", cit. nota n” 30, p. 212.

${ }^{53} \mathrm{El}$ art. $416 \mathrm{CP}$ se limita a establecer que "es injuria toda expresión proferida o acción ejecutada en deshonra, descrédito o menosprecio de otra persona".

${ }^{54}$ LARENZ, Metodología, cit. nota ${ }^{\circ} 43$, p. 211.

${ }^{55}$ Sin pretender agotar todos ellos; en este sentido BELVEDERE, "Note", cit. nota no 30, p. 115 y SÁNCHEZOSTIZ, "Relevancia", cit. nota $n^{\circ} 30$, p. 212. Otros se refieren a estas situaciones como una clase especial de definiciones "celadas", o "entre paréntesis" (como ocurre en la legislación penal alemana), así FRISCH, "Le definizioni legali”, cit. nota $\mathrm{n}^{\mathrm{0}}$ 38, p. 196 y TARELLO, L'interpretazione, cit. nota $\mathrm{n}^{\text {o }}$ 30, pp. 206-207.

56 Sobre la necesidad de enfrentar y resolver el tema de las definiciones legales distinguiendo según si estamos frente a disposiciones de parte general o especial, EMANUELE, Pier Paolo, Le tecniche di redazione della legge penale nel quadro dei principi costituzionali, Tesis doctoral, Università degli studi di Milano, Facoltà di giurisprudenza, 2009-2010, p. 211 y ss., disponible en http://air.unimi.it [visitado el 19.12.2013] y PARLATO, Le definizioni legislative, cit. nota $\mathrm{n}^{\circ} 29$, pp. 38-39.

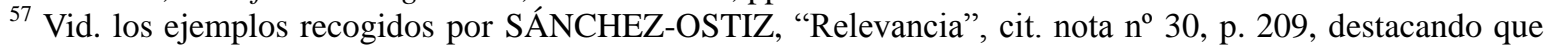
en las leyes elaboradas en tiempos más recientes, recurrir a esta técnica de definiciones parece haberse convertido en una obligación.
} 
OSSANDÓN, María Magdalena. "La técnica de las definiciones en la ley penal:

Análisis de la definición de "material pornográfico en cuya elaboración hubieren sido utilizados menores de dieciocho años".

en el art. 296 respecto del delito de amenazas; la de "acción sexual" en el art. 366 ter, y la de "violencia o intimidación" en el art. 439 relativo a los delitos de robo.

Todos estos ejemplos comparten el hecho de que se trata de definiciones de tipo éstandar, ${ }^{58}$ en que el legislador ha optado por enunciar de modo expreso lo que entiende por una expresión utilizada para describir la conducta penalmente prohibida en un tipo penal. En ellas generalmente aparece en primer lugar el definiendum seguido de una cópula -que nunca se expresa con el verbo "es" sino con expresiones que manifiestan su carácter estipulativo, como "se reputa", "se considera", "se entiende", etc.-, para terminar con el definiens, esto es, el enunciado que expresa su significado.

\section{Clasificación y características de las definiciones legales de la parte especial del Derecho penal}

Entre las múltiples posibilidades de clasificación de las definiciones nos interesa destacar solo aquellas que son relevantes para esta investigación en cuanto permiten mostrar las características propias de las definiciones legales y, en particular, del grupo de definiciones que acabamos de identificar, en el que se inserta la de material pornográfico en cuya elaboración hubieren sido utilizados menores de dieciocho años.

Ya adelantábamos al comenzar, que las definiciones legales pueden caracterizarse como nominales, por oposición a las reales, pues no persiguen dar cuenta de la identidad de la cosa definida sino del sentido de la palabra: "dan significado a un término (el definiendum) por medio de ciertos signos (el definiens)". 59

En relación con el método que se emplee para definir, las definiciones pueden ser connotativas o extensionales. Las connotativas -o también llamadas intensionales- son aquellas en que el definiens se refiere a todas las características o propiedades que un objeto debe poseer para ser identificado con el término en cuestión. ${ }^{60}$ Las definiciones extensionales o denotativas, en tanto, consisten en la enumeración del conjunto de objetos a los que se refiere el definiendum, es decir, los objetos adscritos al término definido, a los que puede ser correctamente aplicado, y en los que se agota su ámbito de aplicación.

A diferencia de otras que tienen un carácter marcadamente connotativo, como la definición de funcionario público o de acción sexual, la que nos interesa es extensional. En su definiens aparece una lista de términos o, más bien, de situaciones diversas a las que se puede aplicar correctamente el definiendum. Son tres situaciones: i) toda representación de los menores dedicados a actividades sexuales explícitas, reales o simuladas, ii) toda representación de las partes genitales de los menores con fines primordialmente sexuales, o

\footnotetext{
58 HERNÁNDEZ MARÍN, Introducción, cit. nota $\mathrm{n}^{\mathrm{o}}$ 30, p. 303, que se diferencian de las indirectas, las condicionales y las incidentales (pp. 309-311).

${ }^{59}$ SÁNCHEZ-OSTIZ, "Relevancia”, cit. nota n' 30, p. 211.

${ }^{60} \mathrm{Si}$ no incluyera todas las condiciones necesarias para la aplicación del término, se trataría sólo de un enunciado que fija ciertas características del término sin llegar a definirlo, cfr. TARELLO, L'interpretazione, cit. nota $n^{\circ} 30$, pp. 211-214 e ITURRALDE SESMA, Lenguaje legal, cit. nota no 29, pp. 54-55.
} 


\section{Polít. crim. Vol. 9, No 18 (Diciembre 2014), Art. 1, pp. 279-337. \\ [http://www.politicacriminal.cl/Vol_09/n_18/Vol9N18A1.pdf]}

iii) toda representación de dichos menores en que se emplee su voz o imagen, con los mismos fines. Este listado ha de entenderse en forma disyuntiva a fin de interpretar correctamente la disposición, la que puede considerarse una definición "si y sólo si la lista de términos es exhaustiva", ${ }^{61}$ pues si entre los elementos recogidos no se incluyeran todos los que caen dentro del concepto, no estaríamos más que ante una descripción o enumeración explicativa. Una verdadera definición existe si se refiere a una lista o registro sustitutivo del definiendum, de modo que a través de ella queden precisados los criterios de uso del término, ${ }^{6}$ estableciendo una equivalencia recíproca entre el definiendum y cada una de las situaciones planteadas. ${ }^{63}$ En otras palabras y ejemplificándolo con una de ellas, que el "material pornográfico en cuya elaboración hubieren sido utilizados menores de dieciocho años" es calificado como "toda representación de los menores dedicados a actividades sexuales explícitas, reales o simuladas"; y a la inversa, que "toda representación de los menores dedicados a actividades sexuales explícitas, reales o simuladas" es calificada como "material pornográfico en cuya elaboración hubieren sido utilizados menores de dieciocho años".

El principal defecto de este método denotativo viene dado porque, en sentido lógico, existe prioridad de la intensión respecto de la extensión. Es decir, que la determinación de los objetos a los que un término puede ser aplicado correctamente -su extensión- depende que estos posean "algunos atributos comunes o características que nos conducen a usar el mismo término para denotarlos" ${ }^{64}$ y no es fácil que a través del enunciado de los diversos objetos a los que se aplica el término se consiga comunicar esos criterios de uso.

Ahora bien, al referirse a cada una de las diversas situaciones a las que es aplicable el término, en el art. 366 quinquies el legislador alude a los atributos o características necesarias que forman el significado de cada una de ellas; en cada una de las hipótesis descritas el significado "supone la existencia de algún criterio para decidir, para cualquier objeto, si cae o no dentro de la extensión del término"; ${ }^{65}$ y como se trata de tres situaciones diversas a las que se aplica el mismo definiendum, lo lógico es que detrás de estas tres exista el mismo criterio de decisión.

En este sentido, sin perjuicio del análisis particular que luego haremos sobre este art. 366 quinquies, podemos advertir desde ya que por tratarse de una definición que sirve para completar la formulación de un tipo penal y para determinar, en el fondo, cuáles son las conductas prohibidas, la descripción de esos atributos necesarios del definiendum debería guardar una íntima vinculación con el bien jurídicamente protegido por las figuras en que dicho definiendum se inserta. Algo que, con más o menos acierto, se vislumbra en la definición de funcionario público del art. 260 cuando se refiere a quien ejerce una función pública, o en la definición de violencia o intimidación en las personas del art. 439, en

\footnotetext{
${ }^{61}$ HERNÁNDEZ MARÍN, Introducción, cit. nota no 30, p. 308.

${ }^{62}$ OSSANDÓN WIDOW, La formulación, cit. nota $\mathrm{n}^{\circ}$ 40, p. 257.

${ }^{63}$ "La definición legal es equivalente a una conjunción de dos enunciados cualificatorios, cada uno de los cuales es el enunciado recíproco del otro", HERNÁNDEZ MARÍN, Introducción, cit. nota n 30, p. 304. Similar SGARBI, "Legislative Definition", cit. nota no 30, pp. 28 y 35.

${ }^{64}$ COPI, Irving; COHEN, Carl, Introducción a la lógica, trad. de la $8^{a}$ edición: GONZÁLEZ RUIZ, Edgar; CHÁVEZ CALDERÓN, Pedro, México: Limusa, 1995, p. 185.

${ }^{65} \mathrm{COPI} / \mathrm{COHEN}$, Introducción a la lógica, cit. nota ${ }^{\circ}$ 64, p. 185 (destacado en el original).
} 
OSSANDÓN, María Magdalena. "La técnica de las definiciones en la ley penal: Análisis de la definición de "material pornográfico en cuya elaboración hubieren sido utilizados menores de dieciocho años".

cuanto alude a "cualquier otro acto que pueda intimidar o forzar a la manifestación o entrega". 66

En general, para explicar la intensión de un término se utiliza una definición por género y diferencia específica, ${ }^{67}$ identificando la clase, que es el género, y las subclases, que son las especies. En nuestro caso, el material pornográfico en cuya elaboración hubieren sido utilizados menores de dieciocho años tiene como género el que se trate de una representación, en cualquier forma, y la diferencia específica se refiere al objeto sobre el que recae dicha representación: los menores dedicados a actividades sexuales explícitas, reales o simuladas; las partes genitales de los menores con fines primordialmente sexuales; o dichos menores empleando su voz o imagen, con los mismos fines.

Por último, en atención a la función que pueden cumplir las definiciones se clasifican en lexicales, también llamadas informativas o analíticas, y estipulativas o sintéticas. ${ }^{68}$ Las primeras son aquellas por las que se describe un uso ya dado a un término en un determinado lenguaje, es decir, se explica o aclara un significado pre-existente. Entonces, según si la definición se corresponde o no con dicho uso se podrá decir que es verdadera o falsa. En el ámbito legislativo esta clase de definiciones no resulta operativa ni conveniente; porque cuando el legislador asume la tarea de definir una palabra del lenguaje ordinario, generalmente pretende precisar, ampliar o restringir su significado. Definir un término sin intención de modificar en nada ese uso resultaría inútil y podría comportar inconvenientes, porque lo aparta de las fluctuaciones del lenguaje ordinario, poniendo en peligro el proceso comunicativo con los destinatarios de la norma. Por lo demás, tampoco podría decirse que las definiciones del legislador pudieran tener un carácter meramente informativo, ${ }^{69}$ porque siempre dotan al término definido de un sentido especial dentro del Derecho.

Las definiciones estipulativas, en tanto, son aquellas que establecen que un término será usado de cierta manera por su autor o un grupo de personas, de tal modo que instauran un significado, sin limitarse a declararlo. ${ }^{70}$ Puede tratarse de la introducción de un término totalmente nuevo, o de una modificación o precisión respecto de un uso ya existente. En este último caso se habla de redefinición o definición explicativa, para algunos una

\footnotetext{
${ }^{66}$ Pero ambas definiciones agregan también hipótesis que quedan fuera de esa referencia al bien jurídico, la primera, porque incluye también a los que tienen un "cargo público", aunque no signifique ejercer función pública alguna; y la segunda, porque añade también una forma de "violencia ficta". Sobre esto, en sentido crítico, OSSANDÓN WIDOW, M. Magdalena, "Sobre la calidad de empleado público en los delitos funcionarios y la punibilidad de quienes no la poseen", Revista Doctrina y Jurisprudencia Penal, Facultad de Derecho, Universidad de Los Andes y Abeledo Perrot-Legal Publishing, $N^{\circ} 8$ (2012), pp. 45-82, pp. 51-61; y OLIVER CALDERÓN, Guillermo, Delitos contra la propiedad, Santiago: Legal Publishing, 2013, p. 281, respectivamente.

${ }^{67}$ Para algunos, el único tipo genuino de definición; para otros, la forma más corriente, pero habría otros como la definición sinónima o la definición operativa, cfr. COPI/COHEN, Introducción a la lógica, cit. nota $\mathrm{n}^{\circ}$ 64, pp. 191-193.

${ }^{68}$ Sobre esta distinción vid., a título ejemplar, COPI/COHEN, Introducción a la lógica, cit. nota $\mathrm{n}^{\circ}$ 64, pp. 173-177 y ROBINSON, Richard, Definition, Oxford: Oxford University Press, 1954, pp. 35-93.

${ }^{69}$ Cfr. ALCHOURRÓN/BULYGIN, "Definiciones y normas", cit. nota no 44, p. 21.

${ }^{70}$ Pese a lo cual, "quien define no es libre de prescindir de los usos del lenguaje y de los significados que los términos ya tienen en éste", SÁNCHEZ-OSTIZ, "Relevancia", cit. nota nº 30, p. 211, n. 15.
} 


\section{Polít. crim. Vol. 9, No 18 (Diciembre 2014), Art. 1, pp. 279-337. \\ [http://www.politicacriminal.cl/Vol_09/n_18/Vol9N18A1.pdf]}

categoría diferente, intermedia entre las lexicales y las estipulativas, ${ }^{71}$ pero que comparten la característica de estas últimas en orden a que no están sujetas a juicios de verdad.

Las legislativas se configuran como definiciones estipulativas, pues indican cuál es el significado atribuido al definiendum dentro del discurso legal. ${ }^{72}$ Incluso puede afirmarse que ellas tienen una doble fuerza instauradora: "no solo instauran un significado, sino que además el significado entra en una norma legal jurídico-penal para servir a los fines de ésta" ${ }^{73}$ Pero como lo normal es que el legislador se base en el significado común de las palabras -así sucede en el caso que nos interesa-, el enunciado legal que fija su significado constituye, más exactamente, una redefinición. Desde este punto de vista, su operatividad se puede concretar en los siguientes objetivos: ${ }^{74}$

a) Dar mayor precisión a un término, asignándole un contenido determinado, necesario cuando la palabra puede ser objeto de interpretaciones multívocas, o cuando no ostenta un significado claro, sea en el terreno jurídico sea en el contexto social; ${ }^{75}$

b) Alterar el significado gramatical, usual o semántico de un término, o el que tiene conferido en otro ámbito del ordenamiento jurídico, para conferirle un contenido menor o mayor, es decir, para restringir o ampliar su alcance, o incluso eventualmente, introducir un término nuevo. ${ }^{76}$ En la práctica, lo cierto es que "las definiciones no suelen ser restrictivas, sino ampliatorias respecto al significado del definiendum en el lenguaje vulgar o en otros sectores". 77

71 Así, ATIENZA, Manuel, El sentido del Derecho, Barcelona: Ariel, 2001, p. 43; COPI/COHEN, Introducción a la lógica, cit. nota $\mathrm{n}^{\circ}$ 64, pp. 177-179 e ITURRALDE SESMA, Lenguaje legal, cit. nota $\mathrm{n}^{\circ} 29$, p. 42. Las incluyen entre las estipulativas ALCHOURRÓN/BULYGIN, "Definiciones y normas", cit. nota ${ }^{\circ}$ 44, p. 21; CAPELLA, Juan Ramón, El derecho como lenguaje, Ariel: Barcelona, 1968, p. 262; CARRIÓ, Genaro, Notas sobre derecho y lenguaje, $2^{\mathrm{a}}$ ed., Buenos Aires: Abeledo Perrot, 1979, p. 118, y el propio autor de la distinción, ROBINSON, Definition, cit. nota n $^{\circ}$ 68, p. 61.

${ }^{72}$ Las define, precisamente, como una "importante técnica legislativa en virtud de la cual se atribuye significación a las palabras utilizadas por la ley para una determinada materia", VIDAL OLIVARES, "La técnica legislativa", cit. nota n ${ }^{\circ} 37$, p. 339 (el destacado es nuestro).

${ }^{73}$ SÁNCHEZ-OSTIZ, "Relevancia”, cit. nota n 30, p. 214.

${ }^{74}$ Por todos, MORALES PRATS, “Omnis definitio”, cit. nota no 35, pp. 318-319.

${ }^{75}$ Este es el sentido que se le puede atribuir, por ejemplo, a la definición de acción sexual

${ }^{76}$ Pero esta última es una posibilidad absolutamente excepcional. Incluso los términos técnicos y técnicojurídicos suelen tener una tradición jurídica, y para determinar su sentido se puede recurrir al uso de los especialistas (por eso tampoco es necesario definirlos en la ley penal), cfr. ALCHOURRÓN/BULYGIN, "Definiciones y normas", cit. nota n' 44, pp. 22-23.

77 Lo constata SÁNCHEZ-OSTIZ, "Relevancia”, cit. nota no 30, p. 213, para el caso español, y lo propio puede decirse de nuestra legislación penal, pues tienen ese sentido las definiciones de armas (art. 132), funcionario público (art. 260, al menos en relación con el concepto administrativo de funcionario; y art. 251 ter); familia (art. 296; al menos esa era claramente la finalidad original, teniendo en cuenta que a la fecha de dictación del Código penal -en que se incluía esta definición- la familia era concebida de un modo muchísimo más restringido); y violencia o intimidación (art. 439, especialmente en lo que se refiere a la violencia ficta). Por el contrario, en la teoría se tiende a asignar a las definiciones únicamente la función de reducir la ambigüedad o vaguedad de un término o de clarificar su significado, vid. referencias de nota $\mathrm{n}^{\mathbf{0}} 35$. MORALES PRATS, "Omnis definitio", cit. nota n 35, p. 326, presupone la intención del legislador de conseguir mayor certeza, pero advierte que no siempre lo consigue. 
OSSANDÓN, María Magdalena. "La técnica de las definiciones en la ley penal: Análisis de la definición de "material pornográfico en cuya elaboración hubieren sido utilizados menores de dieciocho años".

Aunque por su carácter convencional estas definiciones no pueden ser sometidas a un juicio de verdad, eso no significa que ellas queden liberadas de toda forma de control, pues son enjuiciables desde distintos puntos de vista: en cuanto a su corrección formal, por el respeto a las reglas sintácticas del idioma y las reglas de la lógica; en atención a la coherencia del discurso normativo; y en razón de su oportunidad o conveniencia para el funcionamiento del sistema. ${ }^{78}$ En estos últimos aspectos centraremos nuestro análisis sobre la definición de material pornográfico en cuya elaboración hubieren sido utilizados menores de dieciocho años, el que será precedido por un estudio sobre el cumplimiento de las directrices técnico formales que, desde un punto de vista lógico, son exigibles respecto de cualquier definición.

\section{Directrices lógico-formales y técnicas para una correcta definición legal}

Existen una serie de reglas lógicas de carácter general y abstracto que sirven para evaluar si una definición es o no satisfactoria, a las que se pueden añadir otras relativas más específicamente a las definiciones contenidas en la ley. A continuación revisaremos si la definición que es objeto de nuestro estudio cumple con estos requisitos formales, comunes a cualquier ley si se hace abstracción de su objeto y contenido concretos. ${ }^{79}$

Entre las primeras encontramos las siguientes: ${ }^{80}$

a) Una definición debe enunciar los atributos esenciales de la especie. Considerando que nos estamos refiriendo a una definición nominal, entonces la regla se refiere a "aquellos atributos cuya posesión constituye el criterio convencional por el cual decidimos si un objeto es o no denotado por el término". ${ }^{81}$ Pero cuando se trata de definiciones legales, de carácter estipulativo, es difícil determinar que se cumpla adecuadamente con esto o, incluso, que la regla sea aplicable, porque el "criterio convencional" con el que habría que confrontar la definición no es el del uso ordinario, sino el que corresponde mejor a la función que se le asigna a la regulación en que ella se inserta. Como la definición estipulativa es una propuesta de uso, no puede ser calificada como verdadera ni falsa, sino sólo como ventajosa o no, clara u oscura, precisa o imprecisa, útil o inútil, adecuada o no dependiendo de su objetivo. ${ }^{82}$

\footnotetext{
${ }^{78}$ En este sentido, BELVEDERE, "Note”, cit. nota no 30, pp. 116-117; ITURRALDE SESMA, Lenguaje legal, cit. nota no 29, p. 58 y SÁNCHEZ-OSTIZ, "Relevancia", cit. nota no 30, p. 214.

${ }^{79}$ Parafraseando lo que se dice en GRETEL, La forma de las leyes. 10 estudios de técnica legislativa, Introducción, Barcelona: Bosch, 1986, p. 9.

${ }^{80}$ Recogemos las reglas clásicas de COPI/COHEN, Introducción a la lógica, cit. nota no 64, pp. 196-200; con algunas diferencia también planteadas por COHEN, Morris; NAGEL, Ernest, Introducción a la lógica y al método científico, trad.: MIGUEZ, Nestor, $2^{\mathrm{a}}$ ed. en castellano, Buenos Aires: Amorrortu, 1971, pp. 58-62.

${ }^{81}$ COPI/COHEN, Introducción a la lógica, cit. nota $\mathrm{n}^{\circ}$ 64, p. 197.

${ }^{82}$ Cfr. PARLATO, Le definizioni legislative, cit. nota no 29 , p. 33 y SGARBI, "Legislative Definition", cit. nota $\mathrm{n}^{\circ} 30$, p. 30 y 33. Para el caso de redefiniciones, si se considera que ellas son en parte lexicográficas y en parte estipulativas, entonces son susceptibles de verdad o falsedad solo en la medida en que deben ajustarse a lo establecido por el uso ordinario; pero si son totalmente incompatibles con el significado preexistente, más que "redefiniciones falsas" pasan a ser "definiciones estipulativas" sin más.
} 


\section{Polít. crim. Vol. 9, No 18 (Diciembre 2014), Art. 1, pp. 279-337. \\ [http://www.politicacriminal.cl/Vol_09/n_18/Vol9N18A1.pdf]}

b) Una definición no debe ser circular, esto es, el definiendum no debe aparecer en el definiens. Si se trata de una definición por género y diferencia específica, como es el caso, queda también proscrito el uso de cualquier sinónimo del término que se quiere definir, pues de ese modo no tiene lugar ningún avance lógico en el análisis del concepto. ${ }^{83}$ La definición que analizamos no es objetable en este sentido, pues no supone el conocimiento o comprensión del término que es definido.

c) Una definición no debe ser demasiado amplia ni demasiado estrecha. El definiens no debe denotar más cosas que las denotadas por el definiendum. Lógicamente, al construir una definición estipulativa no se puede violar esta regla; ${ }^{84}$ pero en el ámbito jurídico y al complementar este análisis lógico formal con criterios sobre conveniencia y funcionalidad, podremos evaluar la precisión y exhaustividad que debería tener una definición determinada. ${ }^{85}$

d) Una definición no se debe expresar en un lenguaje ambiguo, oscuro o figurado. Esta regla se asocia con que la principal finalidad de las definiciones es ofrecer claridad y certeza sobre el significado de los términos definidos, a través de un lenguaje adecuado y correctamente utilizado, dando prioridad al empleo del lenguaje ordinario. ${ }^{86} \mathrm{El}$ art. 366 quinquies en principio no parece contradecir esta regla, pero lo cierto es que el análisis lingüístico y de la estructura gramatical nos muestra problemas que analizaremos con detalle más adelante, algunos de los cuales parecen inevitables por las características propias del lenguaje. $^{87}$

e) No se debe dar una definición negativa si se puede construir una afirmativa, pues así se puede delimitar mejor su significado, salvo que se trate de términos esencialmente negativos. ${ }^{88}$ La definición de material pornográfico del art. 366 quinquies cumple sin problemas esta regla, escapando a la tendencia -especialmente en la jurisprudencia norteamericana $^{89}$ - a incorporar el elemento negativo relativo a la ausencia de un sentido literario, artístico, político o científico en el material. ${ }^{90}$

${ }^{83}$ COHEN/NAGEL, Introducción, cit. nota $\mathrm{n}^{\circ} 80$, p. 60.

${ }^{84}$ Cfr. COPI/COHEN, Introducción a la lógica, cit. nota $\mathrm{n}^{\circ}$ 64, p. 198.

${ }^{85}$ Sabiendo que estas cualidades son poco logradas, en general, y como dice BARAHONA NOVOA, Alberto, "Aproximaciones a la definición jurídica", Kañina, Revista Artes y Letras, U. Costa Rica, XXXIII, Especial (2009), pp. 47-56, p. 49, "se trata del desiderátum de toda definición, más que un requisito de la definición jurídica".

${ }^{86}$ Sobre la prioridad del lenguaje ordinario como regla básica de técnica legislativa, vid. OSSANDÓN WIDOW, La formulación, cit. nota $\mathrm{n}^{\circ} 40$, pp. 56-59.

${ }^{87}$ Vid. infra 9.1 .

${ }^{88}$ Como "huérfano" que significa un niño que no tiene padres, o "calvo" que alude a no tener pelo.

${ }^{89}$ En particular desde el caso Miller v. California de 1973, con repercusiones en la construcción doctrinal del concepto en países como España y Chile, a las que se refiere OXMAN, "Aspectos político-criminales", cit. nota $\mathrm{n}^{\mathrm{o}} 14$, pp. $256-257$.

${ }^{90}$ En Italia, el art. 529 CP define actos y objetos obscenos con una referencia negativa, particularmente importante toda vez que la caracterización positiva es de una indeterminación extrema. Dice: "Atti e oggetti osceni: nozione. I Agli effetti della legge penale, si considerano osceni gli atti e gli oggetti che, secondo il comune sentimento, offendono il pudore. / Non si considera oscena l'opera d'arte o l'opera di scienza, salvo che, per motivo diverso da quello di studio, sia offerta in vendita, venduta o comunque procurata a persona minore degli anni diciotto". 
OSSANDÓN, María Magdalena. "La técnica de las definiciones en la ley penal: Análisis de la definición de "material pornográfico en cuya elaboración hubieren sido utilizados menores de dieciocho años".

Además, los estudios propios del ámbito legislativo suelen contener otras reglas aplicables a las definiciones legales, que se suman a las anteriores: ${ }^{91}$

f) Debe definir sólo si es necesario. La necesidad de una definición se determina en relación con las funciones que ha de cumplir en orden a proporcionar una mayor certeza y delimitar las posibilidades de interpretación judicial. ${ }^{92}$ Por eso, ellas tienen sentido cuando se plantean en relación con una palabra que no ostenta un significado claro y preciso, cuando ostenta más de un significado, cuando se pretende alterar el significado natural o usual de un término corriente o el significado técnico de una palabra que proviene de una determinada ciencia o $\operatorname{arte}^{93} \mathrm{o}$, por último, cuando se quiere introducir un término nuevo. La definición de material pornográfico parecería, en principio, responder a la primera razón, esto es, la de delimitar uno término de vaguedad e imprecisión considerable; pero hemos visto que para introducirla se invocó, más bien, la necesidad de alterar el sentido de estos términos, ampliándolos a situaciones que parecían escapar de su significado natural y obvio. ${ }^{94}$

g) Explicitar lo que se está definiendo. El artículo 366 quinquies inciso segundo indica expresamente que se está refiriendo a lo que debe entenderse por material pornográfico en cuya elaboración hubieren sido utilizados menores de dieciocho años, esto es, lo que generalmente se denomina material pornográfico infantil o de menores. ${ }^{95}$

h) Explicitar lo definido cuando se usa en el sentido definido. Las disposiciones en que se emplea el término definido -el artículo 366 quinquies inciso primero y el 374 bis- se refieren al definiens expresamente y en los mismos términos a como hace, al definirlo, el art. 366 quinquies inciso segundo, con la única diferencia que intercalan una referencia al soporte en que estuviera: "material pornográfico, cualquiera sea su soporte, en cuya

\footnotetext{
${ }^{91}$ Vid. SALVADOR CODERCH, Pablo, "Definiciones y remisiones", en: SAINZ MORENO, Fernando; DA SILVA OCHOA, Juan Carlos (coords.), La calidad de las leyes, Vitoria: Parlamento Vasco, 1989, pp. 157182, pp. 166-171, en cuya exposición nos basamos. Dan reglas más o menos similares, BARAHONA NOVOA, “Aproximaciones”, cit. nota nº 85, pp. 48-50; HERNÁNDEZ MARÍN, Introducción, cit. nota no 30, pp. 311-316; MUÑOZ QUESADA, Hugo Alfonso, "La situación de la técnica legislativa en Costa Rica", en: RODRÍGUEZ CHANG, Ronny (ed.), La técnica legislativa en Centroamérica y República Dominicana, San José, Costa Rica: Instituto Interamericano de Derechos Humanos, 2000, pp. 73-153, p. 151 y SGARBI, "Legislative Definition", cit. nota no 30, pp. 35-36.

${ }^{92}$ Tampoco son útiles aquellas definiciones que no son usadas nunca por el legislador en otros enunciados, cfr. HERNÁNDEZ MARÍN, Introducción, cit. nota ${ }^{\circ} 30$, p. 314, con ejemplos de ello en el ordenamiento jurídico español. La que estamos estudiando apenas supera este mínimo, pues es aplicable en dos enunciados: el del art. 366 quinquies inciso primero y el del art. 374 bis.

${ }^{93}$ VIDAL OLIVARES, "La técnica legislativa", cit. nota n ${ }^{0} 37$, p. 340, parece limitar la necesidad de definir a estos casos de alteración de significado: "Será necesario hacerlo cuando las palabras de los enunciados sean tomadas por el legislador en un sentido diverso del natural y obvio, según el uso general de las mismas, o bien cuando, tratándose de palabras técnicas, se tomen en un sentido diverso de que les dan los que profesan la ciencia o arte a que pertenecen".

${ }^{94}$ Para "incluir supuestos fácticos que han sido incorporados en la legislación comparada, tales como las imágenes con niños virtuales. Es necesario también que el concepto de pornografía infantil abarque todas formas [sic] en que se puede cometer el delito, para evitar que de otro modo queden impunes", Historia de la Ley $N^{\circ} 19.927$, cit. nota $\mathrm{n}^{\mathrm{o}} 24$, p. 7.

${ }^{95}$ Sobre su denominación, vid. supra nota ${ }^{\circ} 10$.
} 
Polít. crim. Vol. 9, № 18 (Diciembre 2014), Art. 1, pp. 279-337.

[http://www.politicacriminal.cl/Vol_09/n_18/Vol9N18A1.pdf]

elaboración hubieren [hayan] sido utilizados menores de dieciocho años". Aunque la redacción resulta extensa, es preferible una mención explícita y equivalente en cada caso en que se use el término definido, para hacer evidente la necesidad de aplicar la definición legal.

i) No definir varias veces y de modo distinto una misma expresión. Si esta directriz se entiende solo en relación con una misma ley o Código, resulta bastante obvia, aunque no por eso menos importante. Pero consideramos que, además y dentro de los límites de lo posible, se puede extender a todo el ordenamiento jurídico, pues en él "debe tenderse a la unidad, de manera que una palabra tenga siempre el mismo significado en un cuerpo legal o en varios de ellos. Todo ello aconseja no emplear en múltiples sentidos cada palabra"; "96 "el lenguaje jurídico aspira a ser monosémico". ${ }^{97} \mathrm{Al}$ menos cuando desde distintas ramas del Derecho se debe regular una misma materia, se debería propender a que los términos sean empleados en un mismo sentido. Si fuera necesario, por las características y funciones de cada sector del ordenamiento jurídico, asignarles un sentido diferente, entonces resulta aconsejable acudir a expresiones similares pero no idénticas, las que deberán ser definidas expresamente. En otras palabras: para expresar significados distintos deben utilizarse términos distintos, y los mismos términos se deben utilizar siempre con el mismo significado. ${ }^{98}$ Por lo mismo, el recurso a definiciones legales en sede penal es especialmente aconsejable cuando la materia regulada es también objeto de una regulación extrapenal. ${ }^{99}$

Lamentablemente, la misma expresión "material pornográfico" parece tener varios sentidos diversos en nuestro ordenamiento jurídico. Por una parte, el que le asigna la Ley $\mathrm{N}^{\mathrm{o}} 19.846$, sobre calificación de la producción cinematográfica, que lo define expresamente para los efectos de esa ley. Por otra, el de la definición del art. 366 quinquies, cuando en su elaboración hubieren sido utilizados menores de dieciocho años. Y por último, el que se le pueda asignar en el art. 366 quáter o en el art. 411 quáter, en que no son directamente aplicables ninguna de las definiciones previas. ${ }^{100}$

j) Al definir, delimitar lo mejor posible el ámbito de aplicación de la definición. En relación con esta regla la disposición del art. 366 quinquies es bien específica, pues delimita el ámbito de aplicación a solo dos artículos al disponer que "[p]ara los efectos de este artículo y del artículo 374 bis, se entenderá por material pornográfico en cuya elaboración hubieren sido utilizados menores de dieciocho años...”.

k) Las definiciones deben ser, en la medida de lo posible, autosuficientes, que no sea necesario acudir a otra disposición para completarlas; aspecto en el cual nuestra definición no ofrece mayores inconvenientes.

\footnotetext{
${ }^{96}$ TAPIA VALDÉS, La técnica legislativa, cit. nota $\mathrm{n}^{\mathrm{o}}$ 31, p. 72.

${ }^{97}$ BARAHONA NOVOA, "Aproximaciones", cit. nota $\mathrm{n}^{\circ} 85, \mathrm{p} .49$.

${ }^{98}$ Así SGARBI, "Legislative Definition”, cit. nota $n^{\circ} 30$, p. 35.

99 En ese sentido MORALES PRATS, “Omnis definitio", cit. nota no 35, p. 329 y PARLATO, Le definizioni legislative, cit. nota $\mathrm{n}^{\circ} 29$, p. 46.

${ }^{100}$ Sobre esto vid. infra 9.3 .
} 
OSSANDÓN, María Magdalena. "La técnica de las definiciones en la ley penal:

Análisis de la definición de "material pornográfico en cuya elaboración hubieren sido utilizados menores de dieciocho años".

l) Las definiciones deben situarse sistemáticamente al inicio de la ley o de la parte de la ley a la que afectan. Si el uso de la expresión precede a la definición, debe hacerlo de modo inmediato, y si "un término que sólo aparece en una sección de la ley, debería ser definido en esa sección". ${ }^{101}$ La definición que nos ocupa está ubicada inmediatamente después de la primera disposición que la emplea -el inciso primero del art. 366 quinquies- y antes de la segunda -el art. 374 bis-, pero no resulta del todo adecuado que se refiera a disposiciones contenidas en dos párrafos diversos. La primera en el $\$ 6 \mathrm{Del}$ estupro y otros delitos sexuales, y la segunda en el $\S 8$ De los ultrajes públicos a las buenas costumbres. Más que un defecto de la definición, parece serlo de la forma como están ordenados los tipos penales respectivos.

m) Las reglas que establecen definiciones no deben contener, además, disposiciones de otra índole. Aunque el art. 366 contiene tanto la descripción típica de un delito como una definición, cada una está ubicada en incisos separados y bien delimitados, por lo que la cuestión no parece importar mucho. ${ }^{102}$

Revisadas estas reglas formales básicas, es menester abocarnos ahora a un estudio más de fondo relativo a si la definición que estudiamos es funcional y armónica con las necesidades dogmáticas y político-criminales de la materia específica de que se trata.

\section{Evaluación de contenido: legitimidad, legalidad y eficacia}

Para evaluar la técnica utilizada al definir más allá de las cuestiones meramente formales, vamos a aplicar los criterios que hemos identificado en un trabajo previo, ${ }^{103}$ a través de los cuales es posible abarcan las tres dimensiones de la validez del Derecho, ${ }^{104}$ esto es: a) la legalidad formal o validez dogmática, referida a su dimensión normativa, a su formulación en términos lógicos, en relación con las reglas de funcionamiento que corresponden al Derecho como sistema; b) la legitimidad o justicia, esto es, su dimensión ideal, racional, axiológica o filosófica; referida a los valores que inspiran el Derecho y que éste trata de realizar, y c) la eficiencia, dimensión fáctica o sociológica, de confrontación con la realidad social a la que debe ser sometido el sistema jurídico, y que se refiere a la obediencia al mismo, así como a los resultados empíricos que produce.

Estos criterios de evaluación, por los que pretendemos dar cuenta de los aspectos más significativos a considerar cuando se trata de formular un tipo penal, son los siguientes: la capacidad comunicativa de que deben gozar las normas, la economía en su formulación, la sistematicidad, las consideraciones sobre su aplicación efectiva y consecuencias empíricas,

\footnotetext{
${ }^{101}$ VIDAL OLIVARES, “La técnica legislativa”, cit. nota $\mathrm{n}^{\mathrm{o}} 37, \mathrm{p} .340$.

${ }^{102} \mathrm{La}$ exigencia expuesta suele justificarse para evitar confusiones cuando se hace una remisión a la disposición que contiene la definición legal, vid. SGARBI, "Legislative Definition”, cit. nota n 30, p. 36.

${ }^{103}$ Vid. OSSANDÓN WIDOW, La formulación, cit. nota n 40 , pp. 269 y ss.

104 Sobre el reconocimiento de estas dimensiones o momentos dentro del proceso histórico de validez del Derecho, vid., entre muchos, FALCÓN Y TELLA, María José, Concepto y fundamento de la validez del Derecho, Madrid: Universidad Complutense, 1994, pp. 29-59 y MONTORO BALLESTEROS, Alberto, El Derecho como sistema normativo: naturaleza y función del Derecho, Murcia: Universidad de Murcia, 1993, pp. 13-17.
} 


\section{Polít. crim. Vol. 9, No 18 (Diciembre 2014), Art. 1, pp. 279-337. \\ [http://www.politicacriminal.cl/Vol_09/n_18/Vol9N18A1.pdf]}

y el respeto por los principios de subsidiariedad, proporcionalidad, igualdad, legitimidad democrática y seguridad jurídica. El estudio se cierra con un balance en términos de justicia, en que se integran todos los valores para equilibrarlos de modo proporcionado en el supuesto concreto.

Como punto de partida de nuestro análisis debemos advertir que, dada la necesidad de determinación de la ley penal, a la hora de decidir y evaluar el recurso a definiciones legales en la ley penal lo esencial parece ser su capacidad para garantizar una mayor seguridad jurídica y uniformidad en la aplicación del Derecho. Pero junto a ello hay que reconocer que el legislador no puede pretender resolver todas las cuestiones sobre las que puedan aparecer dudas sino que tiene que proporcionar sólo las líneas fundamentales de la decisión valorativo-penal, dentro de una normativa que resulte aplicable a la multitud de situaciones a las que se verá enfrentada, lo que implica la necesidad de limitar el empleo de definiciones.

"Desde esta perspectiva, la regla básica de técnica legislativa es que se debe otorgar prioridad al empleo del lenguaje ordinario, tal como es entendido en el interior de una determinada sociedad. Definir los términos de la ley ha de ser, por tanto, un recurso excepcional, no exento de inconvenientes y limitaciones, y cuya oportunidad estará condicionada, fundamentalmente, por la necesidad de conseguir uniformidad en la aplicación del Derecho y por su propia capacidad para contribuir a ello". ${ }^{105}$

\subsection{Capacidad comunicativa}

En el ámbito de la parte especial que nos ocupa, las normas jurídico-penales pueden caracterizarse como el significado prescriptivo de las expresiones lingüísticas utilizadas en la ley; de ahí que una adecuada técnica legislativa deba procurar que la redacción de los enunciados legales asegure la transmisión fluida y clara de ese mensaje normativo, que se dirige a los ciudadanos como destinatarios de la norma primaria o de conducta, y a los jueces, destinatarios de la norma secundaria o sancionatoria.

Entendiendo que para los ciudadanos las normas primarias constituyen imperativos o directivos de conducta, es indispensable que -directa o directamente- lleguen a conocerlas. Un sujeto podrá ser motivado por la norma y será capaz de adecuar su conducta conforme a ella (o le será exigible hacerlo) sólo en la medida en que reciba el mensaje normativo. Desde una perspectiva técnico-legislativa, lo que el valor de la comunicabilidad exige es que no sea la redacción del mensaje normativo o su deficiente transmisión, la que cimente las bases de un error de prohibición invencible de los destinatarios de la norma. ${ }^{106}$

\footnotetext{
${ }^{105}$ OSSANDÓN WIDOW, La formulación, cit. nota no 40, pp. 265.
}

${ }^{106}$ Especialmente si partimos de la consideración de que la evitabilidad del error de prohibición constituye un problema normativo y no psicológico, cfr. JAKOBS, Günther, Derecho penal. Parte General, trad.: CUELLO CONTRERAS, Joaquín/SERRANO GONZÁLEZ DE MURILLO, José Luis, Madrid: Marcial Pons, 1995, $\S 19 / 35$, p. 674 y, entre nosotros, VAN WEEZEL, Alex, Error y mero desconocimiento en Derecho penal, Santiago: Legal Publishing, 2008, p. 44. 
OSSANDÓN, María Magdalena. "La técnica de las definiciones en la ley penal: Análisis de la definición de "material pornográfico en cuya elaboración hubieren sido utilizados menores de dieciocho años".

Ahora bien, hay que convenir en que el conocimiento de lo que resulta penalmente prohibido o prescrito se produce a través de muy diversos mecanismos, que en su mayoría actúan de modo indirecto. ${ }^{107}$ La capacidad comunicativa que directamente se le asigna a la formulación de la ley penal es más bien escasa, salvo cuando esos mecanismos no estén presentes. De ahí que, entre las diversas funciones que cumple el lenguaje técnico-jurídico, se suele considerar que la función operativa está por sobre la informativa. ${ }^{108}$

Para conseguir un efecto comunicativo mínimamente satisfactorio es primordial el uso de un lenguaje comprensible y claro, lo que abona, en principio, la opción por el lenguaje ordinario o común al efectuar la descripción típica. Sin embargo, la verdad es que no importa tanto la clase de lenguaje que se utiliza como la inteligibilidad del mensaje. ${ }^{109}$ Por eso, el legislador puede recurrir a un lenguaje técnico o especializado cuando sea necesario, sin renunciar a un mínimo de comprensibilidad general. ${ }^{110}$

Cuando se emplean definiciones legales se apunta a esto último, redefiniendo las palabras para darles un significado más especializado y propio del ámbito jurídico. Es cierto que de este modo y por su carácter estipulativo, las definiciones legales alteran los procesos normales de comunicación que requiere una comunidad lingüística a la que pertenezcan todos los involucrados en la actividad normativa, ${ }^{111}$ lo que puede considerarse una característica negativa desde el punto de vista que estamos analizando. Pero como la comunicación no es posible si no se comparten ciertos parámetros mínimos sobre el significado de las palabras, cuando el legislador necesita utilizar una expresión que es desconocida para sus destinatarios, que es difícil de entender, que admite diversas interpretaciones, que adolece de excesiva vaguedad o que requiere ser usada en un sentido que difiere del uso común, definirla expresamente puede ser la mejor forma de asegurar que se comprenda el mensaje normativo. ${ }^{112}$

107 SILVA SÁNCHEZ, Aproximación, cit. nota $\mathrm{n}^{\circ}$ 2, p. 256. Incluso autores como ATIENZA, Manuel, Contribución a una teoría de la legislación, Madrid: Civitas, 1997, p. 42, destacan la necesidad de un análisis empírico-sociológico para establecer cuáles son los canales adecuados para que una ley sea conocida, determinando el papel que desempeñan los medios de comunicación directa (Diario Oficial, Códigos, etc.), los de comunicación indirecta (prensa, radio, televisión, etc.) e incluso medios completamente informales (parientes, amigos, etc.).

${ }^{108}$ Ello se debe, fundamentalmente, al hecho de que: a) la información es algo que se produce sólo de modo mediato, b) no se puede decir que la ley esté referida al ciudadano, pues en tal caso tendría que estar concebida de modo más concreto, popular y corriente, y debería -además de ordenar- explicar y enseñar, c) la función de la ley no es sólo la fundamentación, sino, por sobre todo, la limitación del poder del Estado (función de garantía), lo que explica el lenguaje peculiar de la ley, que no informa sino que da garantía de seguridad jurídica.

109 "El legislador, antes de utilizar una palabra, debe percatarse de su exacto significado, a fin de que la idea jurídica que expresa mediante ella pueda ser evocada con precisión", TAPIA VALDÉS, La técnica legislativa, cit. nota $\mathrm{n}^{\mathrm{o}} 31, \mathrm{p} .72$.

${ }^{110}$ LARENZ, Metodología, cit. nota no 43, p. 316.

111 Lo destacan ALCHOURRÓN/BULYGIN, "Definiciones y normas", cit. nota no 44, pp. 14 y 21; ITURRALDE SESMA, Lenguaje legal, cit. nota no 29, p. 57; ORRÙ, "Le definizioni”, cit. nota nº 47, p. 155 y SGARBI, "Legislative Definition", cit. nota n 30 , p. 35 (por lo que sugiere que, en todo caso, se recurra solo a redefiniciones).

112 Acentúa la funcionalidad comunicativa de las definiciones, por la necesidad de compartir un mismo vocabulario, SGARBI, “Legislative Definition”, cit. nota n 30, pp. 28-29 y 33. 


\section{Polít. crim. Vol. 9, No 18 (Diciembre 2014), Art. 1, pp. 279-337. \\ [http://www.politicacriminal.cl/Vol_09/n_18/Vol9N18A1.pdf]}

Como ya hemos advertido, varias de estas razones son aplicables al empleo de la expresión "pornografía" y sus derivados, ${ }^{113}$ especialmente la necesidad de delimitar un término de vaguedad e imprecisión considerable, y según se argumentó al incorporarla, la necesidad de alterar el sentido de estos términos, ampliándolos a situaciones que parecían escapar de su significado natural y obvio. ${ }^{114} \mathrm{~A}$ ellas se añade, por lo demás, que estamos ante una expresión que tiene una importante carga emotiva que contribuye a su indeterminación, ${ }^{115}$ al ser expresiones que llaman la atención sobre sí mismas y tienen la virtud de provocar reacciones emotivas, que en este caso son de desaprobación. ${ }^{116}$ En hipótesis como ésta, una definición permite sustituir ese efecto en la medida en que utilice referencias libres de esa connotación sentimental. ${ }^{117}$ Otras expresiones son consideradas todavía más cargadas de significado emotivo, como por ejemplo, los términos "obsceno" 118 o "impúdico", 119 por lo que han sido paulatinamente abandonadas en las diversas legislaciones. ${ }^{120}$

Por otra parte, si dentro del proceso de normativización se logra mantener de modo homogéneo un mismo significado para un mismo término en todas las disposiciones en las que aparezca utilizado, se puede terminar por configurar una práctica de uso estable y definida, que cubra la brecha inicial de incomprensión y aumente la seguridad jurídica. ${ }^{121}$ En este sentido, debemos recordar que los enunciados legislativos son recibidos más directamente por los destinatarios de las normas secundarias, esto es, los jueces, mientras que la comunicación con los destinatarios de la norma primaria o de conducta suele realizarse por medios indirectos y puede resultar mejor en la medida en que el texto sea, al menos, comprensible para los expertos.

\footnotetext{
${ }^{113}$ Incluso en países en los que no existe una definición expresa en la ley penal, el término también puede alejarse de su sentido ordinario por la necesidad de acudir a la legislación extrapenal, como recomiendan MORALES PRATS, Fermín; GARCÍA ALBERO, Ramón, "Delitos contra la libertad e indemnidad sexual", en: QUINTERO OLIVARES, Gonzalo (dir.), Comentarios a la Parte Especial del Derecho penal, $8^{\mathrm{a}}$ ed., Pamplona: Aranzadi - Thomson Reuters, 2009, pp. 283-380, p. 350.

${ }^{114}$ Vid. supra nota $\mathrm{n}^{\mathrm{o}} 25$.

115 Sobre este tema, vid. CARRIÓ, Notas, cit. nota no 71, pp. 22-25, NINO, Carlos Santiago, Introducción al análisis del Derecho, $4^{\mathrm{a}}$ ed., Barcelona: Ariel, 1991, p. 269 y OSSANDÓN WIDOW, La formulación, cit. nota $\mathrm{n}^{\mathrm{o}} 40, \mathrm{p} .72-73$.

${ }^{116}$ La opinión pública considera peligrosa la pornografía infantil, asociada al abuso sexual infantil y la pedofilia, cfr. WILLIAMS, Katherine, “Child Pornography Law: Does it Protect Children?”, Journal of Social Welfare and Family Law, No 26, 3 (2004), pp. 245-261, p. 245.

${ }_{117}$ En este sentido SGARBI, "Legislative Definition", cit. nota no 30, pp. 29-30.

${ }^{118}$ En Argentina, por ejemplo, la ley N²5.087 de 7 de mayo de 1999 sustituyó en el artículo 128 la expresión obsceno por pornográfico, aunque en su momento el cambio no fue considerado un gran avance para la determinación del tipo penal, cfr. DONNA, Edgardo Alberto, Delitos contra la integridad sexual, Buenos Aires: Rubinzal-Culzoni, 2000, p. 167; antes de eso, el mismo autor hacía un extenso análisis sobre las diversas formas de concebir lo obsceno, en Derecho penal. Parte especial, tomo I, Buenos Aires: RubinzalCulzoni, 1999, pp. 495-499.

${ }^{119}$ En el antiguo Código penal español se sustituyó la expresión escrito impúdico por escrito pornográfico, modificación que fue calificada como una gran modernización por DÍEZ RIPOLLÉS, José Luis, Exhibicionismo, pornografía y otras conductas sexuales provocadoras, Barcelona: Bosch, 1982, p. 277.

${ }^{120}$ En Italia se mantiene una referencia a los actos u objetos obscenos, definidos en el art. 529 CP.

${ }^{121}$ Cfr. SAINZ MORENO, Fernando, "La técnica normativa: visión unitaria de una materia plural", en: CORONA FERRERO, Jesús María; PAU VALL, Francesc; TUDELA ARANDA, José (coords.), La técnica legislativa a debate, Madrid: Tecnos, 1994, pp. 19-47, p. 43.
} 
OSSANDÓN, María Magdalena. "La técnica de las definiciones en la ley penal: Análisis de la definición de "material pornográfico en cuya elaboración hubieren sido utilizados menores de dieciocho años".

Pero aunque la idea de incluir una definición sobre lo que se entiende por material pornográfico para efectos penales no resulta criticable en sí misma, ${ }^{122}$ la del art. 366 quinquies presenta varios problemas desde la perspectiva que ahora analizamos.

Para empezar, porque se define un término - material pornográfico- solo en función de una situación bien específica: cuando en su elaboración hubieren sido utilizados menores de dieciocho años, lo que implica que cuando se usen esas mismas expresiones en otras situaciones, sin que estén involucrados menores, su significado será diverso. ${ }^{123}$

Otro aspecto cuestionable de la definición es que ella lo sea del material pornográfico infantil y no de la pornografía infantil, como hace el Protocolo Facultativo que le sirvió de modelo. ${ }^{124}$ Cuando se alude al material se está haciendo referencia, en primer lugar, al soporte o medio por el cual se entrega un determinado contenido, ${ }^{125}$ cuestión que es omitida en la definición contenida en el art. 366 quinquies inciso segundo $\mathrm{CP}$ en cuanto alude directamente al contenido de este material: la representación. La definición del Protocolo es más adecuada al referirse a la pornografía infantil como una representación, agregando que ella puede hacerse por cualquier medio. Con todo, en la práctica se entiende que existe una sinonimia entre ambas expresiones y el defecto descrito no tiene mayores repercusiones.

Si analizamos ahora el contenido de la definición, podemos apreciar que ella está expresada en lenguaje ordinario, usando palabras relativamente sencillas y fáciles de comprender. Pero sabiendo que "todas las palabras son vagas, esto es, que su campo de referencia es indefinido, pues consiste en un núcleo o zona central y un nebuloso círculo exterior de incertidumbre", ${ }^{126}$ podemos advertir que algunas ofrecen mayores cuotas de incertidumbre. Es lo que ocurre con las referencias a una representación, actividades sexuales y fines primordialmente sexuales.

Brevemente, baste mencionar que una representación es, según el diccionario de la RAE, una "figura, imagen o idea que sustituye a la realidad", un concepto bastante amplio referido a cualquier captación que se haga de un menor, que no está limitado en relación con el soporte o medio en el que deba quedar plasmado. Se ha discutido si incluye solo representaciones visuales o también las captaciones de sonido, ${ }^{127}$ pero como no existe una

\footnotetext{
122 En contra COX LEIXELARD, Juan Pablo, Los abusos sexuales, Santiago: Lexis Nexis, 2003, pp. 186188, por la imposibilidad de lograr un concepto adecuado, llegando a proponer que se prescinda de toda referencia al material pornográfico.

${ }^{123}$ Que podrá ser el que el que le asigna la Ley $\mathrm{N}^{\mathrm{o}} 19.846$, sobre calificación de la producción cinematográfica, que lo define expresamente para los efectos de esa ley; u otro, cuando dicha definición tampoco resulta aplicable.

${ }^{124}$ Sobre esto VENEGAS CAMPOS, Andrea, Definición legal de material pornográfico en el Código Penal chileno, Memoria para optar al grado de Licenciado en Ciencias Jurídicas, PUCV, 2014, p. 47.

125 "La acepción material pornográfico equivaldría a todo soporte, independientemente de su naturaleza, que contenga o manifieste una conducta pornográfica; verbigracia libros, revistas, fotografías, pinturas, vídeos, películas, DVD, CD's, disquetes de 31/2, disco duro de ordenador", MORILLAS FERNÁNDEZ, Análisis dogmático, cit. nota $\mathrm{n}^{\circ} 9$, p. 249.

${ }^{126}$ ROSS, Alf, Sobre el derecho y la justicia, trad.: CARRIÓ, 2a ed., Buenos Aires: Eudeba, 1997. p. 170.

${ }^{127}$ En nuestro medio, expresamente ha planteado el tema MOLINA CANTILLANA, Delitos de pornografía infantil, cit. nota $\mathrm{n}^{\circ}$, pp. 64-65 quien se inclina por un concepto amplio, mientras que SÁNCHEZ
} 


\section{Polít. crim. Vol. 9, No 18 (Diciembre 2014), Art. 1, pp. 279-337. \\ [http://www.politicacriminal.cl/Vol_09/n_18/Vol9N18A1.pdf]}

limitación expresa a lo visual -al modo como se hace en algunas definiciones del ámbito europeo- y luego de la incorporación de la tercera hipótesis de lo que se entiende por material pornográfico en cuya elaboración hubieren sido utilizados menores de dieciocho años, esto es, la que se refiere a toda representación de dichos menores en que se emplee $s u$ voz o imagen, debemos inclinarnos por un concepto amplio en este sentido.

Podría cuestionarse si el concepto alude solo a una imagen de lo real o si abarca también ideas que no son reflejo de una realidad concreta y específica. Pero la interpretación sistemática de la definición, que se refiere a una representación de éstos, es decir, de los menores utilizados en la elaboración del material, lleva a concluir que los casos de pornografía propiamente virtual o de pornografía técnica, en que no se ve involucrada ninguna persona menor de edad real, no son abarcados. ${ }^{128}$

La referencia a actividades sexuales alude a un núcleo evidente relativo a las conductas que impliquen acceso carnal, por vía vaginal, anal o bucal, o introducción de objetos por las mismas vías, así como a lo descrito en la ley como acciones sexuales según el art. 366 ter. $^{129}$

Se ha planteado que esta referencia podría exceder de esos supuestos para abarcar también situaciones como las previstas en art. 366 quáter sobre corrupción de menores. ${ }^{130}$ Sin embargo, ello solo sería posible si los menores intervienen activamente y no como meros observadores, pues la definición se refiere a que se los represente dedicados a actividades sexuales, ${ }^{131}$ es decir, son los menores quienes deberán realizar una acción de significación sexual delante de otro, y en ese caso su conducta podría considerarse como actividad sexual subsumible en el tenor del art. 366 ter.

En este aspecto la definición de material pornográfico infantil incorpora en su seno los problemas que ha generado la interpretación del art. 366 ter, pues se enfrenta a "una

PECAREVIC, Claudio, Delito de almacenamiento de pornografía infantil, Santiago: Librotecnia, 2010, p. 84, requiere que se trate de una representación visual, siguiendo una opción defendida para otros ordenamientos jurídicos y con argumentos propios de su legislación (vgr. en España MORILLAS FERNÁNDEZ, Análisis dogmático, cit. nota nota $\mathrm{n}^{\circ}$ 9, pp. 67-68).

${ }^{128}$ En este sentido MORALES PRATS/GARCÍA ALBERO, "Delitos contra", cit. nota no 113, p. 351, consideran que "en el tipo se proyecta la tutela penal sobre la idea de utilización del menor y no sobre la estricta actividad de creación de un material calificable objetivamente de pornografía relativa o alusiva de menores".

129 "Para los efectos de los tres artículos anteriores [artículos 365 bis, 366 y 366 bis], se entenderá por acción sexual cualquier acto de significación sexual y de relevancia realizado mediante contacto corporal con la víctima, o que haya afectado los genitales, el ano o la boca de la víctima, aun cuando no hubiere contacto corporal con ella".

${ }^{130}$ En este sentido CISTERNAS VELIS, El delito de producción, cit. nota $\mathrm{n}^{\circ} 10, \mathrm{p} .24$.

${ }^{131}$ En cambio en España, donde no existe una definición legal, se plantea una interpretación más amplia de la pornografía que incluye supuestos en que el menor, por ejemplo, se limita a presenciar la conducta obscena protagonizada por mayores de edad, así MORALES PRATS/GARCÍA ALBERO, "Delitos contra", cit. nota no 113, p. 351, aunque no aparezca desnudo. Otros exigen que la presencia del menor forme parte, de algún modo, de la representación en cuestión, cfr. TAMARIT SUMALLA, Josep Maria, La protección penal del menor frente al abuso y la explotación sexual, $2^{\mathrm{a}}$ ed., Pamplona: Aranzadi - Thomson Reuters, 2002 , p. 107. 
OSSANDÓN, María Magdalena. "La técnica de las definiciones en la ley penal:

Análisis de la definición de "material pornográfico en cuya elaboración hubieren sido utilizados menores de dieciocho años".

dificultad común a gran parte de los delitos sexuales, cual es la de establecer los parámetros que permiten determinar qué conductas son portadoras de significación sexual". ${ }^{132}$

Dificultad que reaparece en la referencia a los fines primordialmente sexuales exigidos para las hipótesis que no consisten en una actividad sexual. Ella alude a que las representaciones se realicen con un carácter primordialmente lúbrico o libidinoso, pero no queda claro si esto constituye un requisito subjetivo referido a un especial ánimo del autor de la conducta típica (de procurar la excitación sexual de terceros con el material en cuestión), ${ }^{133}$ si eso ha de juzgarse desde la perspectiva de la persona que realiza un determinado uso de una imagen, ${ }^{134}$ o si debe exigirse "que la captación de la imagen del menor se efectúe en forma tal que el menor participe en la misma con un comportamiento sexualmente provocador", ${ }^{135}$ en cuyo caso estas hipótesis prácticamente podrían quedar subsumidas en la primera.

Al menos resulta evidente que la simple desnudez, por si sola, es insuficiente para calificar como pornográfico el material; ${ }^{136}$ pero la definición no ofrece parámetros para diferenciar como intenta hacer parte de la doctrina- lo pornográfico de lo meramente erótico. ${ }^{137}$ Parece que solo queda aludir, por sobre lo que exige la definición y para no limitarse a la ausencia de otras finalidades - tal como se hace, doctrinariamente, en legislaciones que no contienen definición legal-, a que el:

"conjunto de la obra o espectáculo esté dominado por un contenido y contexto groseramente lúdico o libidinoso, en el que se persigue la excitación o bien la satisfacción de instintos sexuales, verificándose la carencia o cuasi inexistencia de

${ }^{132}$ TAMARIT SUMALLA, La protección penal, cit. nota $\mathrm{n}^{\mathrm{o}}$ 131, p. 106.

${ }^{133}$ Así lo plantea MOLINA CANTILLANA, Delitos de pornografía infantil, cit. nota no 8 , p. 77, si bien lo hace en conexión con el concepto mismo de pornografía y no por la referencia a los fines primordialmente sexuales (mención cuyo sentido es excluir del tipo aquellos actos que no tienen una connotación sexual, como un acto médico, pero que igualmente serviría de apoyo a su interpretación, n. 89). Hay fallos en sentido contrario, como el de la sentencia de la Corte de Apelaciones (en adelante, "SCA") de Concepción, de 12 de mayo de 2006, Rol 201-2006, en que entiende que la expresión fin primordialmente sexual en relación con el delito de producción pornográfica no exige "que lo haga para satisfacer deseos propios o ajenos, como ocurría cuando se regulaba en el artículo 366 quáter”; similar la SCA de Chillán, de 13 de octubre de 2006, Rol 1182006.

${ }^{134}$ Lo que llevaría a una extensión inaceptable de la intervención penal en ámbitos en los que no lo exige la protección de bienes jurídicos, advierte TAMARIT SUMALLA, La protección penal, cit. nota n 131, p. 106.

${ }_{135}$ TAMARIT SUMALLA, La protección penal, cit. nota ${ }^{\circ}$ 131, p. 107.

${ }^{136}$ Aspecto que no parece tan claro en aquellos autores que intentan explicar la ausencia de connotación sexual por referencia a situaciones en que se constatan fines diversos, por ejemplo de carácter médico, así MOLINA CANTILLANA, Delitos de pornografía infantil, cit. nota ${ }^{\circ} 8$, p. 66.

${ }^{137}$ Cfr. SÁNCHEZ PECAREVIC, Delito de almacenamiento, cit. nota $\mathrm{n}^{\circ} 127$, p. 89, pero sin ofrecer criterios concretos para hacerlo. Tampoco nos sirve la propuesta de MORILLAS FERNÁNDEZ, Análisis dogmático, cit. nota $\mathrm{n}^{\text {o }}$ 9, pp. 246-249, de distinguir en función de si existe una conducta sexual explícita o no, pues el mismo define la conducta sexualmente explícita como "todo contacto sexual, incluyendo el genital-genital, oral-genital, anal-genital u oral-anal; entre menores, o entre un adulto y un menor, del mismo u opuesto sexo; brutalidad; masturbación; desarrollo de conductas sádicas o masoquistas; o exhibición lasciva de los genitales o el área púbica del menor" (p. 66). De ese modo incluye en una sola expresión lo que nuestra legislación separa en dos supuestos diferentes: la actividad sexual y la representación de las partes genitales con fines primordialmente sexuales, pero no termina de explicar cómo se decide, frente a un determinado material, si se trata de una exhibición lasciva o no. 


\section{Polít. crim. Vol. 9, No 18 (Diciembre 2014), Art. 1, pp. 279-337. \\ [http://www.politicacriminal.cl/Vol_09/n_18/Vol9N18A1.pdf]}

valores artísticos, literarios, científicos o pedagógicos $[(\ldots)$ y que $]$ alberga potencialmente ofensividad para desviarse de los patrones o estándares dominantes en la sociedad contemporánea en materia sexual". ${ }^{138}$

En relación con esta exigencia, tampoco es claro si la alusión final de la tercera hipótesis, cuando dice que ha de tratarse de una conducta realizada con los mismos fines se refiere solo a fines sexuales o si también es exigible aquí que se trate de fines primordialmente sexuales.

Por último, la redacción de las disposiciones penales de la parte especial debería comunicar, también, la valoración que subyace a la norma, su ratio iuris, cuestión que está en estrecha relación con la determinación del bien jurídico protegido. Al respecto, que la definición analizada sea extensional más que connotativa, unido al hecho de que incluya hipótesis de gravedad diversa, enturbia esta información. Por eso, la doctrina se ha visto en serias dificultades para especificar cuál es el bien jurídico que se quiere proteger en los delitos relacionados con la pornografía infantil.

\subsection{Economía legislativa}

La regulación jurídica debe ser expresada del modo más breve y preciso posible, por medio de un número restringido de disposiciones, cada una redactada de forma concisa y rigurosa. Ello obedece a razones prácticas que apuntan especialmente a la operatividad del sistema jurídico. Así, la economía legislativa se presenta como un interés instrumental y técnico que se justifica en función de otros valores de técnica legislativa.

Entrar a definir todos los términos de la ley no contribuye a la economía legislativa, por lo que el legislador debe usar las definiciones de modo dosificado. ${ }^{139}$ Pero cuando se trata de un término de utilización frecuente y que permita sustituir -con una sola palabra o expresión breve-, una descripción o listado, entonces las definiciones "constituye(n) un factor de economía, que evita repeticiones; abrevia el texto legal y facilita la labor de la inteligencia mediante la fijación y la simplificación de los conceptos". ${ }^{140}$

Entonces la crítica es obvia, pues la definición que analizamos implica una reiteración de una terminología bastante extensa ya en el definiendum "material pornográfico en cuya elaboración hubieren sido utilizados menores de dieciocho años"; y además se aplica solo a dos ilícitos: el del art. 366 quinquies inciso primero y el del art. 374 bis, por lo que no se observa esa capacidad de abreviación que justificaría una definición expresa. Habría sido más conveniente usar una técnica como la del Código penal argentino, que en su art. 128 incorpora la definición en la misma descripción típica, ${ }^{141}$ lo que no obsta a que también otras disposiciones puedan remitirse a lo así estipulado.

\footnotetext{
${ }^{138}$ MORALES PRATS/GARCÍA ALBERO, "Delitos contra", cit. nota n 113, pp. 350-351.

${ }^{139}$ Cfr. QUINTERO OLIVARES, Gonzalo, Parte general del Derecho penal, Elcano, Navarra: Aranzadi, 2005 , p. 57.

${ }^{140}$ TAPIA VALDÉS, La técnica legislativa, cit. nota $\mathrm{n}^{\circ} 31, \mathrm{p} .76$, aunque lo plantea sin las restricciones que nosotros anteponemos.

${ }^{141}$ Art. 128 CP argentino: "Será reprimido con prisión de seis (6) meses a cuatro (4) años el que produjere, financiare, ofreciere, comerciare, publicare, facilitare, divulgare o distribuyere, por cualquier medio, toda
} 
OSSANDÓN, María Magdalena. "La técnica de las definiciones en la ley penal:

Análisis de la definición de "material pornográfico en cuya elaboración hubieren sido utilizados menores de dieciocho años".

Aunque no se refiere directamente a la definición, no podemos dejar de mencionar aquí una crítica por la deficiente técnica empleada en la modificación que la Ley $\mathrm{N}^{\circ} 19.927$ introdujo en la Ley $\mathrm{N}^{\circ} 19.846$ de 2003, sobre calificación de la producción cinematográfica, pues en lugar de limitarse a derogar la disposición que sancionaba la producción de material pornográfico infantil, la reemplazó por otra totalmente innecesaria y que hace una remisión técnicamente imperfecta a las disposiciones pertinentes del Código penal. ${ }^{142}$

\subsection{Sistematicidad}

“Toda norma se integra en un ordenamiento. De él recibe su sentido y su valor jurídico. La primera condición que debe cumplir una norma es, pues, la de ajustarse a las reglas de articulación del ordenamiento jurídico". ${ }^{143}$ En este sentido, la sistematicidad se refiere al aspecto lógico-formal de estructuración del ordenamiento jurídico, que en tanto orden prescriptivo - práctico- debe tener como base una referencia teleológica, es decir, debe estar orientado al cumplimiento de su función, ${ }^{144}$ procurando ofrecer soluciones útiles, uniformes, consistentes y compatibles entre sí, al tiempo de evitar lagunas o redundancias. "En definitiva, la sistematicidad de las normas dice relación tanto con aspectos estrictamente formales de organización como con cuestiones materiales o de contenido". ${ }^{45}$ Ella se manifiesta al interior del orden normativo penal, como sistematicidad interna, y en su relación con las demás ramas del ordenamiento jurídico, como sistematicidad externa.

Desde este punto de vista, las definiciones legales pueden ser valoradas preliminarmente de modo negativo, en tanto "la noción misma de ordenamiento jurídico implica una cierta uniformidad conceptual basada en el lenguaje ordinario", ${ }^{146}$ por lo que apartarse del significado que los términos tienen en ese ámbito debería ser algo muy excepcional y convenientemente justificado. Pero son adecuadas para la sistematicidad externa, porque la técnica de las definiciones "puede ser un instrumento legislativo de integración del Derecho penal con otros sectores del ordenamiento jurídico, que está en condiciones de garantizar reacciones punitivas uniformes y coherentes en evitación de arbitrariedades y de

representación de un menor de dieciocho (18) años dedicado a actividades sexuales explícitas o toda representación de sus partes genitales con fines predominantemente sexuales, al igual que el que organizare espectáculos en vivo de representaciones sexuales explícitas en que participaren dichos menores".

${ }^{142}$ Actualmente el artículo 30 de la Ley N 19.846 prescribe: "La participación en la producción de material pornográfico en cuya elaboración hayan sido utilizados menores de dieciocho años y la comercialización, importación, exportación, distribución o exhibición de ese material, serán sancionadas de conformidad a lo previsto en los artículos 366 quinquies, 374 bis y 374 ter del Código Penal".

${ }^{143}$ SAINZ MORENO, "La técnica normativa", cit. nota no 121, p. 23.

${ }^{144}$ Se debe tener presente la referencia a fines y valores de la política criminal, en la línea de la propuesta de Roxin, así como que estamos en el ámbito de la tipicidad, lo que obliga a considerar los principios y las particulares funciones político-criminales que conciernen a los tipos, como advierte SÁNCHEZ LÁZARO, “Cómo se elabora...?”, cit. nota n 5, pp. 82-83.

${ }^{145}$ OSSANDÓN WIDOW, La formulación, cit. nota $\mathrm{n}^{\circ}$ 40, p. 314.

${ }^{146}$ SAINZ MORENO, "La técnica normativa", cit. nota $n^{\circ} 121$, p. 25. En el mismo sentido TAPIA VALDÉS, La técnica legislativa, cit. nota $\mathrm{n}^{\mathbf{0}}$ 31, p. 76 afirma que "la unidad de significado de las palabras usadas por el legislador se logra, principalmente, a través de la definición, que impide emplearla con sentidos diversos en una misma o en diferentes leyes". 


\section{Polít. crim. Vol. 9, No 18 (Diciembre 2014), Art. 1, pp. 279-337. \\ [http://www.politicacriminal.cl/Vol_09/n_18/Vol9N18A1.pdf]}

oscilaciones interpretativas", ${ }^{147}$ siempre que se delimite bien su ámbito de aplicación y que, en todo caso, se utilicen los mismos términos cuando se emplean en el mismo sentido, recurriendo a otros cuando el significado es diverso.

En nuestro caso, la definición contenida en el art. 366 quinquies inciso segundo no contribuye ni a la sistematicidad interna ni a la externa, al coexistir con otros conceptos en ambos contextos. Ya al interior del Código penal, porque no es aplicable en el contexto del art. 366 quáter que castiga una forma de abuso sexual impropio o indirecto, una de cuyas hipótesis es la de hacer que una persona menor de catorce años vea o escuche material pornográfico, ni en el del art. 411 quáter, entre los delitos de tráfico ilícito de migrantes, que alude al que capte, traslade, acoja o reciba personas para que sean objeto de alguna forma de explotación sexual, incluyendo la pornografía. ${ }^{148}$

Tampoco coincide con el concepto contenido en la Ley $\mathrm{N}^{\circ} 19.846$ de 2003, sobre calificación de la producción cinematográfica, que en su artículo $2^{\circ}$ establece una definición más restrictiva, pues dispone que:

"Para los efectos de esta ley se entenderá por: d) Contenido pornográfico: la exposición abusiva o grosera de la sexualidad o la exposición de imágenes obscenas, con interacciones sexuales más o menos continuas que, manifestadas en un plano estrictamente genital, constituyen su principal fin".

Esta definición era aplicable inicialmente al tipo que sancionaba la producción de pornografía infantil, cuando estaba contemplado en el artículo 30 de esa misma ley.

En todo caso, este es un defecto que ha sido importado de la normativa internacional y que resulta bastante morigerado si pensamos que lo definido no es la expresión material pornográfico, sin más, sino que aquel en que hubieren sido utilizados menores de dieciocho años. De este modo, el definiendum no coincide exactamente con las expresiones utilizadas en otros cuerpos legales o en otras partes de la ley, y no puede afirmarse que exista una contradicción entre ellos. ${ }^{149}$

El mayor problema en realidad es de fondo, en relación con la sistemática interna del Código penal, porque la definición del art. 366 quinquies se refiere a los menores de dieciocho años sin ninguna distinción según tramos de edad, restando valor a su consentimiento en cualquier caso. ${ }^{150}$ Por el contrario, la regulación de los demás delitos

${ }^{147}$ QUINTERO OLIVARES, Parte general, cit. nota $\mathrm{n}^{\circ} 139$, p. 58. En el mismo sentido FRISCH, "Le definizioni legali”, cit. nota $\mathrm{n}^{\circ} 38$, p. 229.

${ }^{148}$ Aunque la expresión aquí es diversa, en general se entiende que cuando nuestro legislador define "material pornográfico infantil" alude igualmente a la "pornografía infantil" tal como está referida en el Protocolo que le sirvió de modelo.

${ }^{149} \mathrm{Al}$ punto que para algunos debería reservarse una terminología totalmente diversa, pues el uso del término "pornografía" en relación con los menores, incluso, trivializa el problema, cfr. WILLIAMS, "Child Pornography Law", cit. nota $\mathrm{n}^{\circ} 116$, p. 245.

${ }^{150}$ Así, al menos, lo ha entendido la jurisprudencia de modo uniforme. Vid., por todas, SCA de Concepción, de 12 de mayo de 2006, Rol 201-2006, donde se afirma que "carece de relevancia el consentimiento que pueda prestar para participar en la producción del material pornográfico si aún no alcanza a la mayoría de edad. El legislador pretendió vedar cualquier posibilidad de consentimiento lícito de un menor de edad" y 
OSSANDÓN, María Magdalena. "La técnica de las definiciones en la ley penal:

Análisis de la definición de "material pornográfico en cuya elaboración hubieren sido utilizados menores de dieciocho años".

sexuales excluye de su ámbito de aplicación aquellos supuestos en que un mayor de catorce años interviene de modo libre. Aparece, entonces, una contradicción o, por lo menos, una descoordinación valorativa relevante. Si se considera que el objeto de protección es la indemnidad sexual o algún otro bien jurídico individual del menor, ${ }^{151}$ "no se vislumbra porqué debe existir un parámetro tan disímil a la hora de delimitar las conductas punibles. Si se estima que no hay riesgo de un eventual daño de envergadura con la práctica de conductas sexuales, el almacenar registros de las mismas no puede ser incriminado en los términos que lo hace nuestro Código". ${ }^{152}$

\subsection{Consecuencias empíricas}

En la actualidad, la orientación a los efectos de las normas se presenta como un importante criterio de legitimación; "desde el momento en que el Derecho penal deja de concebirse como vehículo de un deber ser absoluto y apriorístico, y se asume su esencia instrumental como razón de ser y de actuación del mismo, las consecuencias fácticas que el Derecho penal produce en su entorno pasan a convertirse en objeto primordial de análisis y recepción". 153

En esta perspectiva, podemos distinguir tres aspectos correlacionados. En primer lugar, las normas aspiran a ser eficaces, es decir, a ser respetadas por sus destinatarios: que la mayor parte de los ciudadanos adecúe su comportamiento a lo prescrito, y que en caso de incumplimiento, sean aplicadas por los jueces. En segundo lugar, deben ser efectivas, entendiendo por tal que consigan los objetivos que con ellas se pretenden; en el caso de las disposiciones penales, que se otorgue protección a bienes jurídicos. Y por último, que todo ello se consiga de modo eficiente, lo que se verifica en la medida en que los beneficios conseguidos sean mayores que los costes, sociales e individuales, que la existencia y aplicación de las normas penales llevan consigo.

La eficacia de las normas tiene como presupuesto que su mensaje sea conocido y comprendido tanto por los destinatarios de la norma de conducta como por los encargados de aplicarla. ${ }^{154}$ "El rechazo a cumplir o a aplicar normas confusas, mal elaboradas, teñidas de la sospecha de que quien las dicta no sabe lo que hace o bien pretende algo distinto de lo

SCA de Chillán, de 13 de octubre de 2006, Rol 118-2006, que alude a que el consentimiento no tiene valor exculpatorio (sic) en la producción de material pornográfico.

${ }^{151}$ Sobre esto vid. infra las consideraciones que haremos a propósito de la efectividad en la protección.

${ }^{152}$ COX LEIXELARD, Juan Pablo, "Los delitos de producción, adquisición y tenencia maliciosa de material pornográfico como figuras expansivas del Derecho penal, Revista de Derecho, PUCV Semestre I (2005), pp. 145-154, p. 152.

${ }^{153}$ ALCÁCER GUIRAO, Rafael, "Facticidad y normatividad. Notas sobre la relación entre ciencias sociales y Derecho penal", Actualidad Penal (2001), pp. 229-261, p. 229. En el mismo sentido CALSAMIGLIA, Albert, "Justicia, eficiencia y optimización de la legislación”, Documentación Administrativa No 218-219 (1989), p. 113-151, p. 115 y ss.; MARCILLA CÓRDOBA, Gema, Racionalidad legislativa, Madrid: Centro de estudios políticos y constitucionales, 2005, pp. 339-340 y SILVA SÁNCHEZ, Jesús María, "Eficiencia y Derecho penal", ADPCP (1996), pp. 93-127, passim.

${ }^{154} \mathrm{La}$ incidencia -relativa- de la clase de lenguaje que emplee la ley ha sido analizada en relación con el primer criterio de análisis, vid. supra 8.1 . 


\section{Polít. crim. Vol. 9, No 18 (Diciembre 2014), Art. 1, pp. 279-337. \\ [http://www.politicacriminal.cl/Vol_09/n_18/Vol9N18A1.pdf]}

que dice pretender, es frecuente". ${ }^{155}$ En relación con la definición de material pornográfico en cuya elaboración hubieren sido utilizados menores de dieciocho años, podemos decir que en principio su inclusión facilita el conocimiento de lo prohibido, frente a un concepto indeterminado y variable. Pero lo errático de la evolución legislativa bien puede generar un cierto rechazo para su aplicación; particularmente desde que se agregó la hipótesis relativa a la representación de dichos menores en que se emplee su voz o imagen, que se aleja de lo que internacionalmente se ha entendido por pornografía infantil y permite incluir en la definición hipótesis de gravedad diversa.

Por otra parte, solo se puede aspirar a la eficacia de las normas penales cuando gozan de un cierto grado de aceptación social, sin ser impuestas desde arriba y por sobre las convicciones sociales. ${ }^{156}$ Desde este punto de vista, la amplitud de la definición legal que analizamos respondería, precisamente, a la preocupación social por el fenómeno expansivo de la industria pornográfica y a una demanda ciudadana por un mayor protección de los menores, por lo que no presenta problemas en este sentido.

Para enjuiciar la efectividad y eficiencia de las normas penales es fundamental delimitar cuál es el objetivo o beneficio -legítimo- que con ellas se pretende alcanzar, el que no puede ser otro que la protección de ciertos bienes jurídicos considerados de especial relevancia, protección que se intenta conseguir previniendo las conductas que constituyen las modalidades más graves de ataque contra ellos. Otras funciones que de hecho el Derecho penal pueda realizar -en orden al progreso social o la concienciación de los ciudadanos respecto de ciertos valores fundamentales-, no constituyen su objetivo y, por lo tanto, no justifican los costes que toda decisión incriminatoria trae consigo.

En los delitos relacionados con la pornografía infantil el tema resulta doblemente complejo, por las dificultades para delimitar cuál es el bien jurídico penalmente protegido y por el conflicto que existe entre la libertad de expresión, el derecho a la creación artística y a la intimidad, en contraposición con la peligrosidad de esas conductas dada la especial necesidad de protección de los menores. ${ }^{157}$ La ley, en este sentido, no colabora mucho, pues

\footnotetext{
155 SAINZ MORENO, “La técnica normativa”, cit. nota n $^{\circ} 121$, p. 22.

156 Así SAINZ MORENO, "La técnica normativa", cit. nota $n^{\circ} 121$, p. 22 y SCHÄFFER, Heinz, "Racionalización y creación del Derecho", trad.: MONTORO CHINER, María Jesús, Documentación administrativa No 218-219 (1989), pp. 153-195, p. 187. ROSS, Sobre el derecho, cit. nota $\mathrm{n}^{\circ} 126$, p. 452, agrega que "una ley adoptada en contra de la conciencia jurídica popular, probablemente causará mala voluntad, insatisfacción y fricción, y ello puede tener un efecto indeseable sobre el respeto general a la ley".

${ }^{157}$ Como expresamente se ha planteado en todo el desarrollo de la jurisprudencia norteamericana, analizada por OXMAN, “Aspectos político-criminales", cit. nota $\mathrm{n}^{\circ}$ 14, pp. 255-263. Particularmente representativo de esto son los argumentos esgrimidos por la Corte Suprema de Estados Unidos en el caso New York v. Ferber, de 1982 para diferenciar los supuestos de pornografía infantil de otros casos de pornografía, que fueron los siguientes: "Primero, que el utilizar a menores como sujetos de la pornografía puede ser perjudicial tanto para su salud física como para su bienestar psicológico y, por ello, la pornografía infantil no está comprendida dentro de la protección que dispensa la primera enmienda; segundo, que la aplicación del estándar del caso Miller para configurar la obscenidad no es una solución satisfactoria al problema de la pornografía infantil; tercero, que las ganancias financieras originadas en la venta y publicidad de la pornografía infantil constituyen un incentivo para producir dicho material, lo que está prohibido en Estados Unidos; cuarto, que en el mejor de los casos el valor de permitirles a los menores realizar o aparecer en exposiciones lascivas es insignificante; y, quinto, que la distribución de fotografías y películas que representan actividades sexuales
} 
OSSANDÓN, María Magdalena. "La técnica de las definiciones en la ley penal: Análisis de la definición de "material pornográfico en cuya elaboración hubieren sido utilizados menores de dieciocho años".

su centro de atención es únicamente la representación sin ninguna referencia al daño que se puede haber provocado para hacerla o al peligro que pueda suponer para el menor representado. 158

Ahora bien, respecto del bien jurídico protegido en los delitos sexuales en general, en aquellos en que están involucrados menores, y más específicamente, en los delitos contemplados en los artículos art. 366 quinquies y 374 bis, a los que se aplica la definición, existe una larga controversia a la que no es posible referirnos ahora. Para nuestra finalidad bastará con aludir a que éste suele identificarse, en general, como la indemnidad sexual entendida como aquel "derecho de las personas a no verse involucradas en un contexto sexual, en atención al daño -físico, psíquico o emocional- que tal experiencia puede ocasionar en el común de los seres humanos". ${ }^{159}$ En los delitos de pornografía infantil, parte de nuestra doctrina identifica distintos bienes jurídicos -sea de modo individual o en conjunto, que se añaden o sustituyen a los de carácter sexual-, dependiendo de cuál sea la situación: si se trata de la representación de una situación real o si estamos en supuestos de pseudopornografía, si los afectados son mayores o menores de catorce años, si existe consentimiento o no. ${ }^{160}$ Entre ellos la libertad del menor, su intimidad, su dignidad, su

explícitas realizadas por menores de edad está intrínsecamente relacionado con el abuso sexual de los niños y, por tanto, existe un interés del Estado que justifica o faculta la prohibición de comercialización".

${ }^{158}$ Defecto compartido en otros ordenamientos, cfr. WILLIAMS, "Child Pornography Law", cit. nota no 116, p. 248.

${ }^{159}$ RODRÍGUEZ COLLAO, Luis, Delitos sexuales, Santiago: Editorial Jurídica de Chile, 2000, p. 124.

${ }^{160}$ En esta línea se ubica la doctrina especializada más reciente, que pone el acento en uno u otro bien jurídico según la figura particular de que se trate. Así, CISTERNAS VELIS, El delito de producción, cit. nota $\mathrm{n}^{\circ} 10$, pp. 9-11 y 14-15; CARNEVALI RODRÍGUEZ, "Algunas precisiones", cit. nota $n^{\circ} 164$, p. 11; DE LA FUENTE JIMÉNEZ, Delitos de pornografía infantil, cit. nota $\mathrm{n}^{\circ}$ 8, p. 60-62; MOLINA CANTILLANA, Delitos de pornografía infantil, cit. nota $\mathrm{n}^{\circ}$ 8, pp. 83-86; VERA AZÓCAR, Alejandra; SEPÚLVEDA SÁNCHEZ, Ivonne, "Aproximaciones a los bienes jurídicos protegidos y a las cuestiones concursales en el ámbito de los delitos vinculados a la pornografía infantil", Revista Jurídica del Ministerio Público, $\mathrm{N}^{\circ} 49$ (2011), pp. 198-205.

La posición de nuestros tribunales es más variable. Con referencias directas a la indemnidad sexual, vgr. SCS de 7 de agosto de 2008, Rol 5576-2007 y SCS de 11 de mayo de 2011, Rol 2576-2011. También la SCA de Concepción, de 12 de mayo de 2006, Rol 201-2006, dice que "el bien jurídico protegido por la ley penal, es la indemnidad sexual del menor, esto es, el derecho del menor de edad a desarrollar su sexualidad en forma normal y natural sin interferencia de hechos que por su naturaleza anormal o desviada tengan la capacidad real o potencial para pervertir, corromper o impedir dicho desarrollo"; similares, SCA de Chillán, de 13 de octubre de 2006, Rol 118-2006; Sentencia del Tribunal Oral en lo Penal (en adelante, "STOP") de Ovalle, de 9 de enero de 2010, Rit 16-2009 y STOP de San Antonio, de 4 de julio de 2006, Rol 18-2006, agrega que "tal conducta es indiscutiblemente idónea para socavar la adecuada formación de la personalidad y la libertad sexual de los menores, es decir, para influir o incidir en una personalidad en formación afectando a su normal y futuro desenvolvimiento sexual (...), lo que quiere decir, en otras palabras, que se tutela bienes jurídicos como la libertad e indemnidad sexuales". Aluden también a la protección de la imagen y el honor del menor de edad en función de su desarrollo integral, STOP de Santiago $\left(7^{\mathrm{mo}}\right)$, de 12 de diciembre de 2007, Rit 214-2007; y a la dignidad del menor y al derecho a la propia imagen, pues la exposición de su corporeidad con fines sexuales "importa cosificarlo, reduciendo su propia imagen a un objeto destinado a satisfacer los deseos sexuales de otro, alienándola de su calidad de sujeto y, en definitiva, instrumentalizar una característica primordial en la constitución de la personalidad, nuestra propia imagen", STOP de Melipilla, de 13 de mayo de 2011, Rit 22-2011, y STOP de Santiago (6 $6^{\circ}$, de 29 de junio de 2012, Rit 73-2012. A estos bienes algunos fallos agregan referencias a la moral social colectiva o, si se quiere, al peligro de futuros delitos, vgr. STOP de Santiago $\left(5^{\circ}\right)$, de 11 de diciembre de 2009, pues "se prohíbe la comercialización, 


\section{Polít. crim. Vol. 9, No 18 (Diciembre 2014), Art. 1, pp. 279-337.

honor, o incluso, en algunas hipótesis se advierte que no existiría potencial lesivo para bien jurídico alguno. ${ }^{161}$

En líneas generales, no parece justificado que a través de la definición que comentamos se reúnan formas de pornografía que implicarían un distinto contenido de injusto. Esta diferencia parece particularmente intensa entre los casos de la denominada pornografía infantil expresa, que comprende "aquella conducta sexual explícita desarrollada o en la que participa directamente un menor de edad [...] quedando sujeta a filmación o exhibición", ${ }^{162}$ y aquellos de pseudopornografía, en que el menor no interviene directamente, sino que se emplea su voz o imagen con fines primordialmente lascivos. Si convenimos en que ese menor es la víctima del delito, el titular del bien jurídico -cualquiera sea éste-, podrá verse afectado de modo muy distinto en uno y otro caso. Sin embargo, es necesario matizar esta afirmación, porque los delitos relacionados con la pornografía infantil deben ser, en buena medida, desconectados del hecho mismo que es captado o grabado: si este reúne las características propias de otros delitos sexuales -violación, estupro, abusos sexualesestaremos ante un concurso de delitos, en que la gravedad de esa conducta original será sancionada por esos tipos penales, mientras que el desvalor -añadido- que implica su captación, difusión, etc., sería punible por los tipos relativos a la pornografía. ${ }^{163} \mathrm{Si}$, por el contrario, la conducta captada no configura ningún otro delito, por ejemplo, porque se trata de una actividad sexual simulada, entonces solo se verifica el relativo a la pornografía, en que el hecho tratarse de pornografía expresa no supone necesariamente un mayor desvalor que las hipótesis de pseudopornografía.

adquisición y posesión de cualquier material de contenido pornográfico infantil, con el objeto de evitar despertar los bajos instintos sexuales". En esta línea, confusamente, la SCS de 18 de agosto de 2009, Rol 3557-2009, entiende que "el bien jurídico es la dignidad de los menores, toda vez que se contribuye con la conducta sancionada al mantenimiento y expansión de una nueva y degradante industria, que tiene como presupuesto y objeto la comisión de gravísimos delitos sexuales contra niños y niñas, lo que fue, además, el parecer del legislador chileno en el origen del proyecto de la ley $\mathrm{N}^{\circ} 19.927$, impidiendo la proliferación de la pornografía para lograr la disminución de su demanda"; idea suscrita por la SCA de Valparaíso, de 23 de mayo de 2012, Rol 431-2012, que agrega: "Se quiso sancionar la adquisición y posesión dolosa de pornografía infantil, por tratarse del último delito de una cadena que afecta la dignidad e integridad física y psíquica de los menores, los que son utilizados en prácticas sexuales abusivas y dañinas, las que son reproducidas en diversos soportes, para posteriormente difundir esas imágenes, produciéndose una doble victimización, toda vez que la existencia de demanda de estos materiales justifica su producción y posterior distribución, y quien lo adquiere pasa a ser un testigo o usuario de un delito cometido en forma previa con un menor, lo que requiere ser sancionado".

${ }^{161}$ Un buen resumen de las diversas posiciones doctrinales en CISTERNAS VELIS, El delito de producción, cit. nota $\mathrm{n}^{\circ} 10$, pp. 3-15. Durante la tramitación de la Ley $\mathrm{N}^{\circ} 20.526$ se alude además a la integridad de otros niños, distintos del que aparece en el material, que pueden verse afectados: "El niño que consume hentai, muchas veces quiere experimentar lo que está viendo, creyendo que es normal. No sabe que es una situación que le puede ocasionar daño, lo cual crea el círculo vicioso del abuso sexual infantil" Historia de la Ley $N^{o}$ 20.526, cit. nota $\mathrm{n}^{\mathbf{0}} 28$, p. 31. Especialmente se usa el argumento de que los adultos puedan utilizar la pornografía infantil para seducir a los menores de edad; referencias de la discusión en Estados Unidos en OXMAN, "Aspectos político-criminales", cit. nota n 14, pp. 272 y 275 y en Reino Unido en WILLIAMS, "Child Pornography Law", cit. nota n" 116, pp. 251 y 254.

${ }^{162}$ MORILLAS FERNÁNDEZ, Análisis dogmático, cit. nota no 9, p. 68.

${ }^{163}$ En este sentido VENEGAS CAMPOS, Definición legal, cit. nota n ${ }^{\circ}$ 124, n. 62. 
OSSANDÓN, María Magdalena. "La técnica de las definiciones en la ley penal: Análisis de la definición de "material pornográfico en cuya elaboración hubieren sido utilizados menores de dieciocho años".

Esto nos lleva a concordar con la idea de que si se sanciona la producción del material pornográfico infantil, así como una serie de conductas posteriores de tráfico, difusión, almacenamiento, etc., es porque se ha considerado que a través de esos comportamientos "podría verse afectada la formación sexual del menor, lesionando sus intereses, si éste queda expuesto a la injerencia de terceros, al poder visualizar el material". ${ }^{164}$ En consecuencia, aunque el bien jurídico afectado pueda, eventualmente, tener conexión con la intimidad, el honor y el derecho a la propia imagen de los menores, ello ha de ser siempre en un específico y particular sentido por tratarse de comportamientos de contenido sexual, es decir, en conexión con la idea de indemnidad sexual. ${ }^{165}$ Lo que se protege es el bienestar psíquico-emocional del menor en el proceso formativo conectado con su desenvolvimiento sexual, bien jurídico que podría verse afectado no solo por la realización de ciertas conductas de índole sexual con intervención del menor o su involucramiento en un contexto de ese mismo carácter -en diversa medida según su edad y consentimiento, lo que puede ser captado por otros tipos penales - sino que también por el hecho de elaborar un registro de la actividad del menor o de su cuerpo o su voz, que es lo que sancionan los tipos relativos a la pornografía infantil. ${ }^{166}$

Por eso, en los delitos relativos a la pornografía infantil y, en especial, en aquellos en que solo se ha usado la imagen o la voz del menor, únicamente deben subsumirse en el tipo aquellas conductas que:

“entrañen una lesión para los procesos de formación y socialización de menores [...] (o para su indemnidad, si se prefiere), y no cualquier utilización de imágenes o voces que, por su naturaleza o nula vinculación con el contenido pornográfico del producto en el cual se insertan, carezca de entidad para dañar el bien jurídico". ${ }^{167}$

Exigir que se afecte el proceso de formación no es lo mismo que exigir que el menor efectivamente haya sido lesionado en su desarrollo, pues solo sería necesaria una situación de riesgo para el normal desarrollo del proceso para alcanzar la madurez psicosexual por el que transitan. Para que no estemos ante meras invocaciones vacías de contenido, debe demostrarse que los comportamientos realizados tengan, al menos, la aptitud para afectar este desarrollo del menor. ${ }^{168}$

\footnotetext{
${ }^{164}$ CARNEVALI RODRÍGUEZ, Raúl, "Algunas precisiones respecto de los delitos de producción de material pornográfico infantil, de favorecimiento a la prostitución de menores y de obtención de servicios sexuales", Informe en Derecho $N^{\circ}$ 2/2012, Departamento de Estudios, Defensoría Penal Pública, 2012, pp. 6-10.

${ }^{165}$ La necesidad de interpretar el tipo como un delito que vulnera un valor que se sitúa dentro de la esfera de la sexualidad del ser humano es destacada por RODRÍGUEZ COLLAO, Luis; MAYER LUX, Laura, "La conducta típica del delito de producción de pornografía infanto-juvenil", Revista Doctrina y Jurisprudencia penal: Delitos sexuales, $\mathrm{N}^{\circ} 15,2013$, pp. 25-41, pp. 29-31, fundamentalmente en razón de su ubicación sistemática y de las características particulares del sujeto pasivo al que se refiere.

${ }^{166}$ Así delimitan la conducta típica RODRÍGUEZ COLLAO/ MAYER LUX, "La conducta típica", cit. nota no 165 , p. 32.

${ }^{167}$ ORTS BERENGUER, Enrique, "Delitos contra la libertad e indemnidad sexuales (y III): Exhibicionismo y provocación sexual. Prostitución y corrupción de menores", en: VIVES ANTÓN, Tomás Salvador et al., Derecho Penal. Parte especial, $3^{a}$ ed., Valencia: Tirant lo Blanch, 2010, pp. 279-310, p. 306.

${ }^{168}$ No del todo claras son, en este sentido, las consideraciones de la SCA de Concepción, de 12 de mayo de 2006, Rol 201-2006, cuando afirma que "la conducta ejecutada por el imputado ha lesionado el bien jurídico
} 


\section{Polít. crim. Vol. 9, No 18 (Diciembre 2014), Art. 1, pp. 279-337. \\ [http://www.politicacriminal.cl/Vol_09/n_18/Vol9N18A1.pdf]}

El tema de la diversa gravedad de los supuestos se plantea también al distinguir entre víctimas menores de catorce años y mayores de esa edad. Es cierto que tratándose de menores de catorce años su consentimiento es irrelevante para realizar o intervenir en actividades de significación sexual, lo que hace parecer más grave la producción, comericalización, exhibición y demás conductas prohibidas en relación con el material pornográfico registrado en esos casos. Pero también debemos reconocer, por lo mismo, que si se ha realizado cualquier acto de naturaleza sexual con intervención de un menor de catorce años esa conducta será constitutiva de un delito diverso de los contemplados en los artículos 366 quinquies inciso primero o 374 bis, sancionable junto a estos últimos. De ese modo el mayor desvalor de la conducta es jurídico-penalmente reconocido a través de otro tipo penal.

Por último, en esta línea de consideraciones, también parecen existir divergencias valorativas entre los supuestos en que la captación de imágenes o sonidos ha sido conocida y consentida por el menor involucrado y aquellos en que no, que parecen insuficientemente contempladas en la definición de material pornográfico en cuya elaboración hubieren sido utilizados menores de dieciocho años. Sin embargo, si afirmamos que los delitos relativos a la pornografía infantil protegen un bien jurídico distinto a la intimidad, en aquellos supuestos en que el material pornográfico se elabore sin el consentimiento válido de los menores involucrados habrá que estimar que estamos ante un concurso de delitos generalmente un concurso ideal- entre estas figuras y las que protegen la intimidad (art. $161 \mathrm{~A}),{ }^{169}$ por lo que nuevamente el problema de la diversa gravedad de las hipótesis se resuelve extra muros de los tipos relativos a la pornografía infantil.

Pese a todo, es bien evidente que aún con todas estas advertencias, subsisten diferencias notorias entre las diversas hipótesis incluidas en la definición de material pornográfico infantil, y si se llega a la conclusión de que en alguna de las situaciones incluidas en la definición y sancionadas en virtud de los artículos 366 quinquies y 374 bis CP no es posible identificar un comportamiento con aptitud siquiera para afectar un bien jurídico merecedor de protección penal, pese a muchas otras funciones que la regulación pueda de hecho realizar, la efectividad de la norma penal en que dicha definición se inserta será nula y la intervención penal ilegítima. Aunque esto se relaciona también con las conductas prohibidas - como las de adquirir o almacenar-, incluso en mayor medida que con el contenido de aquello que se adquiere o almacena, ${ }^{170}$ desde una perspectiva de técnica

protegido en el delito previsto en el artículo 366 quinquies del Código Penal, cual es la indemnidad sexual de los menores, originando tal conducta secuelas de carácter físicas, psíquicas y emocionales. No resulta posible dimensionar las reacciones o daños inmediatos que pueda ocasionar un atentado sexual, como tampoco resulta posible realizar un pronóstico certero en cuanto a las consecuencias futuras o mediatas de ese mismo comportamiento. Los informes psicológicos detallados en el raciocinio cuarto de la sentencia de primer grado consignan el daño psicológico que han experimentado los menores víctimas de la conducta del imputado; por vía de ejemplo, trastorno por estrés postraumático, dificultades para conciliar el sueño, sentimiento de culpabilidad, recuerdos recurrentes del acontecimiento y ánimo depresivo"; como se advierte, distingue bien entre las consecuencias psíquicas directamente provocadas y las consecuencias futuras o mediatas, pero entiende afectado el bien jurídico por el daño psicológico actual, sin vincularlo con el proceso de formación sexual del menor.

${ }^{169}$ En este sentido CISTERNAS VELIS, El delito de producción, cit. nota $\mathrm{n}^{\circ}$ 10, pp. 113-114, con apoyo de doctrina española.

${ }^{170}$ Así VENEGAS CAMPOS, Definición legal, cit. nota nº 124, n. 56. 
OSSANDÓN, María Magdalena. "La técnica de las definiciones en la ley penal:

Análisis de la definición de "material pornográfico en cuya elaboración hubieren sido utilizados menores de dieciocho años".

legislativa no es menos cierto que al definir el legislador no puede dejar de considerar que con ello está delimitando o, más bien en este caso, ampliando el alcance de un injusto típico.

Todo lo anterior se relaciona también con lo que ya advertíamos sobre las cuestiones interpretativas que se generan a propósito de algunas referencias empleadas en la definición. Así, por ejemplo, en relación con lo que se debe entender por representación, las consideraciones teleológicas -en el marco de las consecuencias empíricas de las normas, a que ahora aludimos- abonan la idea que la definición solo abarca aquellas referidas a menores reales, quienes asumen el rol de sujeto pasivo del delito; pero no habría problema en incluir tanto las representaciones visuales como las captaciones de sonido, siempre que tengan entidad para afectar un bien jurídico penalmente relevante.

Las dificultades para precisar el contenido de la referencia a actividades sexuales no pueden ser superadas fácilmente por alusión al bien jurídico, pues en los casos límite es difícil determinar qué clase de actividades tendrán ese carácter por resultar aptas para afectar, una vez que son grabadas o captadas, el proceso de formación psicosexual de los menores involucrados.

Por otra parte, la referencia teleológica hace que el requisito de que ciertas representaciones -tanto de las partes genitales del menor como aquellas en que se emplee su voz o imagensean hechas con fines primordialmente sexuales no puede juzgarse desde la perspectiva de la persona que realiza un determinado uso de una imagen, pues eso llevaría a una extensión inaceptable de la intervención penal en ámbitos en los que no lo exige la protección de bienes jurídicos. ${ }^{171}$ Que algunas personas puedan excitarse con la contemplación de fotos en que aparezcan niños desnudos en un libro de anatomía no significa que ellas deban calificarse como material pornográfico; ${ }^{172}$ es necesario que el material mismo tenga la aptitud para afectar la formación sexual del menor. ${ }^{173}$

${ }^{171}$ TAMARIT SUMALLA, La protección penal, cit. nota $\mathrm{n}^{\mathrm{o}} 131$, p. 106.

${ }^{172}$ Es lo que se planteó en la STOP de Valparaíso, de 14 de mayo de 2010, RIT 12-2010, en relación con unas fotografías "en que aparecen niños, jóvenes y/o adultos desnudos asemejan fijaciones de alguna comunidad nudista puesto que muestran escenas absolutamente normales de una familia igualmente normal, sólo que sin ropa y, las restantes, se identifican con una muestra de pasarelas infantil o juvenil", que no satisfacen los requisitos del objeto material del delito, pues este requiere, entre otros, una "tendencia necesaria a la excitación sexual, siendo éste un elemento decisivo al momento de determinar o de calificar la reproducción y, tal circunstancia debe haber sido buscada por el agente puesto que una fotografía, por ejemplo, no basta con que cause excitación en determinado sujeto sino que requiere, para ser calificada de pornográfica, que ésta se haya realizado con el objetivo preciso de causar excitación sexual".

${ }^{173}$ Así se ha planteado en la jurisprudencia española, en relación con un tipo no del todo equivalente a los nuestros, para cuya configuración se exige algo más que un desnudo, con independencia de la motivación de quien utilice el material. Por eso se descarta el delito cuando "la imagen de un desnudo -sea menor o adulto, varón o mujer- no puede ser considerada objetivamente material pornográfico, con independencia del uso que de las fotografías pueda posteriormente hacerse", Tribunal Supremo español, Sentencia 1342/2003, de 20 de octubre [RJ 200317509] cit. por MORILLAS FERNÁNDEZ, Análisis dogmático, cit. nota n 9, p. 254. En el mismo sentido MUÑOZ CONDE, Francisco, Derecho Penal. Parte Especial 16 ${ }^{\mathrm{a}}$ ed., Valencia: Tirant lo Blanch, 2007, p. 225. En Italia, en tanto, la legislación asigna la calidad de obsceno a una obra de arte o de ciencia si "por motivo diverso al de su disciplina, es ofrecida en venta, vendida o de cualquier modo 


\section{Polít. crim. Vol. 9, No 18 (Diciembre 2014), Art. 1, pp. 279-337. \\ [http://www.politicacriminal.cl/Vol_09/n_18/Vol9N18A1.pdf]}

En otro orden de cosas y desde un punto de vista más general, debemos mencionar también el peligro de que la definición legal implique un alejamiento de la realidad y del dinamismo social, en circunstancias en que el buen funcionamiento del Derecho penal -por el carácter pragmático que debe asumir su misma estructura semiótica- exige que éste exista en una sociedad que lo pueda entender en un sentido relativamente determinado. ${ }^{174}$ Precisamente, en algunos países se ha renunciado a establecer una definición legal de pornografía infantil para favorecer la adaptabilidad de los tipos en el tiempo, sin restringir la determinación que el aplicador del derecho pueda hacer del concepto. ${ }^{175}$ Pero, al mismo tiempo, dejar de definir en la ley puede ser disfuncional en la medida en que eso signifique una recarga inútil de trabajo para el aplicador del Derecho y contribuya a la incertidumbre. ${ }^{176}$ Por lo tanto, aunque la regla general debe ser el recurso al lenguaje ordinario sin alteraciones, en ciertas ocasiones - por ejemplo, la excesiva vaguedad y variabilidad que se le asigna, en el lenguaje ordinario, al término pornografía-, resulta más efectivo que sea el legislador quien asuma la tarea de definir. Pero entonces existe el riesgo, como en el presente caso, de que la definición sea muy amplia para evitar su estancamiento y la desprotección del bien jurídico, especialmente por la dificultad de enumerar de manera completa la extensión de un término, ${ }^{177}$ lo que limita su capacidad de significación y da cabida a numerosas situaciones en que difícilmente se estará afectando el bien jurídico.

Finalmente, tal como ocurre en la tipificación de otros delitos, detrás de la punición de las conductas relacionadas con la pornografía infantil subyace la idea de la necesidad de combatir una actividad organizada y expansiva como es la "industria pornográfica", 178 asignándole al Derecho penal una función disuasoria que debería contrarrestar, por la severidad de sus sanciones, los beneficios que dicha industria genera. ${ }^{179}$ Sin embargo, ni la definición de material pornográfico ni los delitos que se remiten a ella contemplan exigencia alguna relativa a que el comportamiento típico sea parte de una cadena organizada de actividades, por lo que se pueden aplicar en situaciones totalmente aisladas, originadas en una grabación casual o con otras características semejantes o, en todo caso,

proporcionada a una persona menor de dieciocho años"; es decir, no tan solo por la motivación del autor, sino por el hecho de llegar a manos de un menor, quien pasaría a ser la víctima del delito.

${ }^{174}$ En este sentido, JORI, "Definizioni legislativa", cit. nota n' 43, pp. 76 y 88 y ORRÙ, "Le definizioni", cit. nota $\mathrm{n}^{\circ} 47$, p. 155.

${ }^{175}$ Se ha soslayado intencionalmente la definición según KÜNSEMÜLLER, "Delitos de pornografía infantil”, cit. nota $n^{\circ}$ 9, p. 11. En Alemania lo reconoce así HANACK, Ernst-Walter, Die Reform des Sexualstrafrechts und der Familiendelikte, en Neue Juristische Wochenschrift, 1974, pp. 1 - 9, y lo mismo ha ocurrido en España, donde se entiende que el concepto debe establecerse "en función de los usos, costumbres y pensamiento social de cada colectividad, época y momento histórico" BLANCO LOZANO, Carlos, Tratado de Derecho Penal Español, Tomo 2 - Vol. 1, Barcelona: Bosch, 2005, p. 15, citados por VENEGAS CAMPOS, Definición legal, cit. nota n 124 , p. 22, n. 44 y p. 25, n. 57.

${ }^{176}$ Cfr. MARTINO, "Definiciones legales", cit. nota n' 41, p. 66.

${ }^{177}$ Cfr. COPI/COHEN, Introducción a la lógica, cit. nota nº 64, p. 188 y TARELLO, L’interpretazione, cit. nota $\mathrm{n}^{\circ} 30$, p. 202.

${ }^{178}$ Argumento invocado por autores como Gimbernat para defender la punibilidad de la posesión de material pornográfico para uso propio, en tanto el consumidor "contribuye al mantenimiento y expansión de una nueva y degradante industria”, cit. por MORILLAS FERNÁNDEZ, Análisis dogmático, cit. nota n 9, p. 181, y reproducido en los mismos términos por nuestros tribunales, vid., por ejemplo, los fallos de la CS de 18 de agosto de 2009, rol 3557-2009 y de la CA de Valparaíso, de 23 de mayo de 2012, rol 431-2012.

${ }^{179}$ En esos términos se planteó el asunto durante la tramitación de la Ley $\mathrm{N}^{\mathrm{o}} 19.927$, vid. Historia de la Ley $N^{o}$ 19.927, cit. nota $\mathrm{n}^{\mathrm{o}} 24$, p. 157. 
OSSANDÓN, María Magdalena. "La técnica de las definiciones en la ley penal:

Análisis de la definición de "material pornográfico en cuya elaboración hubieren sido utilizados menores de dieciocho años".

sin necesidad de probar conexión alguna con esta "industria". En estos supuestos, la penalidad se revela excesiva y poco efectiva, por significar costes sociales y particulares mayores que los beneficios que reporta.

\subsection{Subsidiariedad}

El Derecho penal no es el único sector del ordenamiento que se ocupa de la protección de ciertos bienes, pero es el que cuenta con los instrumentos más drásticos para hacerlo. Por eso, el principio de subsidiariedad - en conjunto con el de fragmentariedad, con el que está en conexión- se manifiesta en que sólo se puede intervenir penalmente allí donde es en absoluto necesario para la protección de bienes jurídicos imprescindibles para la convivencia social, frente a los ataques más graves de que son objeto, cuando no pueden ser protegidos efectivamente por medios menos lesivos. El principio de subsidiariedad implica, en consecuencia, una dimensión negativa o de límite frente al poder punitivo estatal, pero también un aspecto positivo, pues obliga al Estado a tomar todas las posibles medidas jurídicas y político-sociales que ayuden a evitar los delitos sin tener que acudir al Derecho penal.

Ahora bien, este carácter subsidiario no puede identificarse con una subordinación conceptual y funcional a las otras ramas del Derecho, con un supuesto carácter del Derecho penal como meramente sancionatorio y accesorio. En su relación con otros sectores jurídicos el Derecho penal mantiene autonomía y define su espacio propio de conductas sancionables, dentro del cual limita su aplicación por el principio de subsidiariedad.

En la configuración concreta de los ilícitos penales este principio requiere que cada tipo penal plasme en sí las diferencias con los ilícitos extrapenales -especialmente del orden administrativo- que puedan operar en la misma materia o sector de actividad, pues sólo tiene sentido hablar de la subsidiariedad en la medida en que el ilícito penal resulte, al menos, de mayor gravedad que el administrativo. En este sentido, el haber incorporado una definición propiamente penal de lo que se entiende por material pornográfico en cuya elaboración hubieren sido utilizados menores de dieciocho años puede considerarse una reafirmación de esa autonomía, que podría servir para deslindar mejor los ámbitos de aplicación de los tipos penales frente a otras herramientas legales.

Sin embargo, el problema que se presenta en nuestro país es que no existen otros mecanismos específicos para afrontar el problema de la pornografía infantil, especialmente en su dimensión "industrial" a la que antes hacíamos referencia. Aun reconociendo lo difícil que puede ser analizar si otros mecanismos menos severos ofrecen resultados satisfactorios, resulta preocupante que durante la tramitación de la diversas leyes modificatorias del Código penal en estas materias, no se haya siquiera planteado la posibilidad de implementar sistemas extrapenales para enfrentar esta actividad. ${ }^{180}$

\footnotetext{
${ }^{180}$ Cabe recordar, a este respecto, que el Protocolo facultativo no se refiere únicamente a las sanciones penales como mecanismo para proteger a los niños, sino que también obliga a adoptar o reforzar, aplicar y dar publicidad a las leyes, las medidas administrativas, las políticas y los programas sociales, destinados a la prevención de los delitos a que se refiere el Protocolo (art. 9).
} 


\section{Polít. crim. Vol. 9, No 18 (Diciembre 2014), Art. 1, pp. 279-337. \\ [http://www.politicacriminal.cl/Vol_09/n_18/Vol9N18A1.pdf]}

\subsection{Igualdad}

No parece necesario recordar la relevancia del principio de igualdad en el sistema jurídico, pero sí, brevemente, algunas de las características que implica esta obligación de asignar el mismo tratamiento a lo que es igual, $\mathrm{y}$, correlativamente, uno diferente a lo que es desigual.

En primer lugar, estamos ante un concepto puramente formal pues no explica qué es lo igual o desigual, ni cómo se debe tratar a los iguales, o bien a los desiguales; ${ }^{181}$ y relativo, pues no consiste en una cualidad de las personas, normas, etc., sino en una relación de comparación entre dos o más objetos de conocimiento, que se puede colmar con los más diversos contenidos.

"Es necesario, por ende, determinar los extremos de la relación (igualdad entre quiénes), y un término de comparación entre ellos (igualdad en qué). Ninguna situación es del todo igual o diferente a otra, sino que eso se determina siempre según un punto de comparación o tertium comparationis, que es el que determina la identidad parcial o analogía, siempre relativa, a que alude el principio".

Además, es un concepto valorativo relativo a igualdades (o desiguladades) fácticas parciales; ${ }^{183}$ el acto por el cual se equipara o diferencia dos realidades "no reposa sólo en el conocimiento racional, sino significa, siempre y sobre todo, una decisión", ${ }^{184}$ la que se adopta según si las diferencias -siempre existentes-son consideradas relevantes o no.

En el ámbito jurídico-penal, la determinación de lo igual o desigual constituye un punto neurálgico para la construcción del supuesto de hecho del tipo. En él se concreta la decisión de asimilar una serie de supuestos -que quedan comprendidas dentro de una misma descripción típica- en atención a que comparten ciertas características estimadas esenciales en relación con el tertium comparationis que se tiene como referencia, y que en el ámbito legislativo está constituido por la ratio iuris.

Ese mismo efecto se produce por la estipulación de una definición legal, ${ }^{185}$ instrumento a través del cual el legislador concreta y expresa los términos del acto de equiparación entre los objetos asimilados. Esto resulta especialmente evidente cuando estamos ante una definición extensional o denotativa, en que se enumera el conjunto de objetos a los que se refiere el definiendum, los que resultan, en consecuencia, asimilados entre sí. Precisamente, el art. 366 quinquies inciso segundo, al definir lo que se considera material pornográfico infantil, realiza una equiparación expresa de situaciones que son fácticamente bien

\footnotetext{
${ }^{181}$ Cfr. KAUFMANN, Arthur, Filosofía del Derecho, trad.: VILLAR BORDA, Luis; MONTOYA, Ana María, Bogotá: Universidad del Externado, 1999 p. 295.

182 OSSANDÓN WIDOW, La formulación, cit. nota $\mathrm{n}^{\circ}$ 40, p. 521.

${ }^{183}$ Así ATIENZA, Contribución, cit. nota $\mathrm{n}^{\mathbf{0}} 107$, p. 39, ubica la igualdad -conjuntamente con la libertad y la justicia-en el nivel de la racionalidad ética de la norma.

${ }^{184}$ KAUFMANN, Filosofía del Derecho, cit. nota ${ }^{\circ}$ 181, p. 295.

${ }^{185}$ Efecto poco considerado en los estudios de técnica legislativa. Lo insinúa SAINZ MORENO, Fernando, "Los textos normativos. Condiciones de inteligibilidad", en: AA. VV., Actualidad y perspectivas del Derecho público a fines del siglo XX: Homenaje al profesor Garrido Falla, vol. I, Madrid: Ed. Complutense, 1992, pp. 441-471, p. 444.
} 
OSSANDÓN, María Magdalena. "La técnica de las definiciones en la ley penal: Análisis de la definición de "material pornográfico en cuya elaboración hubieren sido utilizados menores de dieciocho años".

diferentes. Lamentablemente, por tratarse de una definición extensional, no se hace explícito el criterio valorativo que la ley ha tenido en cuenta para considerarlas iguales entre sí.

Ya hemos advertido que en el contexto legal el criterio de comparación es la ratio iuris, lo que en el ámbito penal se traduce en el bien jurídico que se pretende proteger. En consecuencia, no resulta adecuado suponer que las diversas situaciones asimiladas dentro del concepto de material pornográfico infantil puedan estar referidas a diversos bienes jurídicos. Todas ellas deberían ser equiparables en función de un mismo bien jurídico. Según lo que acabamos de explicar, podemos convenir en que lo que comparten las hipótesis subsumibles en la definición es su aptitud para afectar el proceso de desarrollo psicosexual de un menor; este es algo así como el mínimo común denominador que justificaría su asimilación. Otros desvalores o características particulares de cada una de las hipótesis no deberían ser considerados aquí, sino que a través de su eventual subsunción en otros tipos penales.

Por el contrario, si al interpretar nuestra definición no pudiéramos más que reconocer que estamos ante hipótesis referidas a distintos bienes jurídicos, o que en relación con un mismo bien jurídico la gravedad de cada una de ellas es diversa en una medida relevante, entonces deberíamos concluir que la técnica empleada es defectuosa. En este sentido, a pesar de todos los esfuerzos que hemos realizado, no se puede negar que la disposición admite subsumir en ella hipótesis de diversa gravedad, especialmente entre aquellas situaciones en que el menor efectivamente ha intervenido en una grabación -aunque la conducta realizada no sea constitutiva de un delito distinto- y aquellas en que solo se utiliza su voz o imagen, sin involucrarlo personalmente.

Por otra parte, en la aplicación concreta de los tipos penales relativos a la pornografía infantil, el recurso a una definición expresa debería servir para garantizar uniformidad y evitar la arbitrariedad, superando la desorientación jurisprudencial que se produce frente a signos linguiísticos con una extensión conceptual tan incierta. Con todo, la dificultad para conocer la justificación valorativa que existe detrás de la definición y las discusiones sobre la eventual ausencia de antijuridicidad material de algunos supuestos en ella incluidos puede provocar reticencias en su aplicación por algunos jueces, favoreciendo interpretaciones restrictivas que vayan más allá del texto formal. Se abre así una puerta a la desigualdad en la aplicación de estos tipos penales, especialmente cuando se trate de casos de pseudopornografía.

En conexión con lo anterior, que ni la definición ni los tipos en que ella es utilizada contemplen las distinciones de edad que se efectúan en el resto de las figuras de carácter sexual -entre mayores y menores de catorce años- representa una diferencia en el trato en comparación con esos otros delitos. Esas distinciones de edad se hacen en el entendido de que los mayores de catorce años, al tener un mayor desarrollo físico y psíquico, pueden consentir válidamente para involucrarse en un contexto sexual; en consecuencia, son "diferenciados" del resto de los menores, y por lo mismo, el tratamiento respecto de ellos es 


\section{Polít. crim. Vol. 9, No 18 (Diciembre 2014), Art. 1, pp. 279-337. \\ [http://www.politicacriminal.cl/Vol_09/n_18/Vol9N18A1.pdf]}

diferente. La definición de material pornográfico, en cambio, prescinde de estas diferencias de un modo que no ha sido adecuadamente justificado.

Tampoco contribuye con la igualdad la subsistencia de diversos conceptos de material pornográfico dentro de la legislación. Aunque la definición que analizamos pudiera colaborar para evitar que cada juez entienda algo distinto en el caso de los delitos relativos a la pornografía infantil, genera una eventual fuente de desigualdad cuando se trata de pornografía en que no son utilizados menores. Incluso dentro de este último contexto, se abre la posibilidad de que algunos tribunales resuelvan los casos dudosos recurriendo a la definición del art. 366 quinquies y otros no.

\subsection{Proporcionalidad}

En lo que aquí interesa, la proporcionalidad (en sentido estricto) consiste en que el sacrificio que se impone al derecho correspondiente guarde un razonable equilibrio o proporción con los bienes que pretenden salvaguardarse; ${ }^{186}$ "la existencia y la entidad de la pena debe reflejar la presencia e importancia de la afección al bien jurídico, así como la concurrencia e intensidad de la responsabilidad del autor". ${ }^{187}$ Es especialmente difícil hacer un juicio de proporcionalidad por ser éste un criterio relativo y valorativo, pese a lo cual la doctrina ha ido identificando algunas pautas de valoración que gozan de legitimidad constitucional y que sirven para determinar la gravedad intrínseca del hecho, como la importancia del bien jurídico protegido, el grado de la ofensa, el desvalor de la acción, la trascendencia social del hecho, el grado de ejecución y las formas de participación. ${ }^{188}$

Ese equilibrio debe verificarse tanto en la conminación legal -proporcionalidad en abstracto- como en la imposición de la pena - proporcionalidad en concreto-, por lo que incumbe tanto al legislador como al juez. Sin embargo, la dificultad de controlar el procedimiento legislativo y de obtener decisiones bien fundamentadas del legislador, ha hecho que el análisis de la proporcionalidad se desplace al ámbito judicial. ${ }^{189}$ Pese a ello, consideramos que el principio de proporcionalidad abstracta admite, al menos, un control intrasistemático, por comparación entre las diversas figuras típicas que se consagran en la ley penal, los bienes jurídicos que protegen y el modo cómo se ven afectados por la conducta típica.

\footnotetext{
${ }^{186}$ Cfr. AGUADO CORREA, Teresa, El principio de proporcionalidad en Derecho penal, Madrid: Edersa, 1999, p. 147, concepto que se inserta dentro de uno más amplio, que abarca también el principio de idoneidad de medio empleado y el de necesidad, aspectos que tienden a consideraciones empíricas y de funcionamiento del sistema, a que ya hemos hecho referencia.

${ }^{187}$ DÍEZ RIPOLLÉS, José Luis, "El derecho penal simbólico y los efectos de la pena", Actualidad Penal (2001), pp. 1-22, p. 8 .

${ }_{188}$ AGUADO CORREA, El principio, cit. nota n ${ }^{\circ} 186$, pp. 286-291.

${ }^{189}$ En este sentido ZUÑIGA AÑAZCO, Yanira, "El principio de proporcionalidad como herramienta de racionalidad. Un análisis crítico de su aplicación en la jurisprudencia del tribunal constitucional chileno", Revista Ius et Praxis, Año 16, № 2 (2010), pp. 249 - 272, p. 261, objeta que el TC considere, prácticamente, que el de proporcionalidad es un principio improcedente en la actividad del legislador (p. 269), aludiendo a la STC Rol 825-07 referente a la constitucionalidad del art. 450 CP (si bien el voto minoritario abogó por exigir proporcionalidad "entre la limitación del derecho fundamental a la libertad y el objetivo constitucionalmente válido que se busca perseguir").
} 
OSSANDÓN, María Magdalena. "La técnica de las definiciones en la ley penal:

Análisis de la definición de "material pornográfico en cuya elaboración hubieren sido utilizados menores de dieciocho años".

Ahora bien, como analizamos una definición, que no establece penas, puede parecer que un juicio de proporcionalidad es totalmente improcedente. Sin embargo, no es menos cierto que nuestra definición está estipulada para la aplicación de ciertos tipos penales, que complementa, por lo que puede hacerse un análisis por referencia a dichos tipos, aun sin entrar a analizar la diversa relevancia que podría existir entre las conductas descritas en los artículos 366 quinquies inciso primero y el 374 bis.

Para lo que aquí interesa, el problema es que la propia definición de material pornográfico infantil reúne hipótesis que pueden ser de muy diversa gravedad, lo que nos llevaría a concluir que las penas no son proporcionadas a cada una de ellas. ${ }^{190}$ Sin embargo, ya matizamos esto al advertir que en los delitos relativos a la pornografía es necesario independizar el desvalor que existe por la producción, difusión, adquisición, etc., del material, de aquel que es propio de la conducta sexual que tienen como base y que podrá ser sancionada por otros tipos penales. Al hacer este ejercicio diferenciador, subsiste únicamente lo que ellas tienen en común, que es su aptitud para afectar el desarrollo y formación psicosexual del menor. Entendiendo que ese es el bien jurídicamente protegido y que solo se exige que sea puesto en peligro, no podemos dejar de considerar que las penas son desproporcionadamente altas en comparación con los demás tipos penales referidos a los bienes semejantes. Seguramente la penalidad se asignó a estos delitos considerando la existencia de una "industria pornográfica" o el peligro de que el consumidor de pornografía pueda cometer posteriores delitos sexuales, pero ninguno de esos aspectos ha sido incorporado en las exigencias típicas, razón por la cual no son exigibles para imponer las penas que los delitos contemplan.

\subsection{Legitimidad democrática}

Este criterio es esencial para valorar una disposición penal considerando que en nuestro sistema el legislador tiene la supremacía por sobre los demás poderes, por ser quien detenta la representación más directa del pueblo. Eso se manifiesta en la exigencia constitucional de legalidad de los delitos y las penas.

Desde este punto de vista, el recurso a definiciones es un mecanismo que contribuye a radicar las decisiones en el poder legislativo, una legítima reivindicación del principio democrático. En cambio, "no definir, no asumir responsabilidad por parte del legislador produce una transferencia de poder político que en muchos casos nos parece francamente inconveniente. Si el legislador no define, deberá definir el aplicador". ${ }^{191}$

La definición legal constituye una forma de interpretación auténtica, por la que el propio legislador declara qué significa un término. ${ }^{192}$ En consecuencia,

\footnotetext{
${ }^{190}$ Aspecto reconocido en la legislación italiana, que permite sancionar supuestos de pseudopornografía pero con una pena reducida en un tercio respecto de la aplicable en los casos de pornografía real (art. 600-quáter 1)

${ }^{191}$ MARTINO, "Definiciones legales", cit. nota no 41, p. 66.

${ }^{192}$ Reconocida así por la generalidad de la doctrina, por todos, TARELLO, L’interpretazione, cit. nota $\mathrm{n}^{\circ} 30$, p. 241.
} 


\title{
Polít. crim. Vol. 9, No 18 (Diciembre 2014), Art. 1, pp. 279-337. \\ [http://www.politicacriminal.cl/Vol_09/n_18/Vol9N18A1.pdf]
}

\begin{abstract}
"facilita conocer la voluntas legislatoris (...) y en tal sentido, una definición legislativa proporciona para la decisión judicial criterios relativamente seguros (...). Además, en la medida en que la definición es declaración explícita del texto de la norma, viene a precisar la finalidad, no ya del legislador, sino de la ley misma. Pueden servir como expresión de la voluntas legis". ${ }^{193}$
\end{abstract}

Así, esta técnica sirve como respuesta ante el desconcierto jurisprudencial, para garantizar que la reacción punitiva sea uniforme y coherente, evitando arbitrariedades y oscilaciones interpretativas. ${ }^{194}$ Aunque ya hemos visto que no debe sobrevalorarse su capacidad en este sentido, al menos es una regla que guía la interpretación y permite excluir algunas opciones hermenéuticas.

En contraposición con lo anterior, cabe recordar que el lenguaje ordinario se forma y vive en la complejidad de la experiencia jurídica, por lo que posee raíces democráticas bastante sustanciales y profundas. ${ }^{195}$ Como las definiciones legislativas tienden a alterar o alejarse de ese significado ordinario, se alejan también de ese sentido democrático profundo.

En nuestro caso, la definición de material pornográfico involucra un concepto técnico que aleja al Derecho de la realidad social en que se desenvuelve, implica una formalización que puede conducirlo al estancamiento y dificulta la comprensión de las normas por parte de sus destinatarios. ${ }^{196}$ Pero como parece que en esta materia el lenguaje ordinario no ofrece alternativas adecuadas para la labor de selección y valoración de las conductas que debe realizar el legislador, resulta necesario este mayor esfuerzo para radicar la valoración penal en el ámbito legislativo a través de la definición.

\subsection{Seguridad jurídica}

Aunque tiene diversas acepciones, como criterio para enjuiciar una técnica legislativa entendemos por seguridad jurídica la "cualidad del ordenamiento que produce certeza y confianza en el ciudadano sobre lo que es derecho en cada momento y sobre lo que previsiblemente lo será en el futuro". ${ }^{197}$ Ella está basada en un aspecto objetivo, relativo a la regularidad estructural y funcional del sistema jurídico a través de sus normas e instituciones, y de uno subjetivo, que consiste en la proyección de las garantías estructurales y funcionales en las situaciones personales, que se traduce en la posibilidad de conocimiento previo de las consecuencias jurídicas de los propios actos. Constituye un objetivo fundamental al que apunta una correcta técnica legislativa, al punto que ella misma ha sido concebida como el "arte de construir un ordenamiento jurídico bien estructurado en

\footnotetext{
${ }^{193}$ Cfr. SÁNCHEZ-OSTIZ, "Relevancia”, cit. nota no 30, p. 223 (destacado en el original).

${ }^{194}$ Como ha sucedido en un derecho tan poco legalista como el del sistema anglosajón, por ejemplo, con la definición de hurto en la Britisch Theft Act de 1968, cfr. JORI, "Definizioni legislativa”, cit. nota n 43 , p. 64.

${ }^{195}$ Cfr. PALAZZO, "Sulle funzioni", cit. nota n n $^{\text {35, p. }} 386$.

${ }^{196}$ En general, OSSANDÓN WIDOW, La formulación, cit. nota no 40, p. 521.

197 SAINZ MORENO, Fernando, voz "seguridad jurídica", en: MONTOYA MELGAR, Alfredo (dir.), Enciclopedia jurídica básica, t. IV, Madrid: Civitas, 1995, p. 6108
} 
OSSANDÓN, María Magdalena. "La técnica de las definiciones en la ley penal:

Análisis de la definición de "material pornográfico en cuya elaboración hubieren sido utilizados menores de dieciocho años".

sus principios e integrado por normas correctamente formuladas, esto es, un ordenamiento que haga efectivo el principio de la seguridad jurídica". 198

La seguridad jurídica está estrechamente vinculada con el principio de legalidad en todas sus manifestaciones, pero entre ellas destaca, en particular, la necesidad de determinación de la ley penal. Esta parece ser la razón fundamental para que el legislador decida hacer uso de una definición legal de expresiones -como la de material pornográfico-, de significado oscuro y extensión conceptual incierta. En efecto, las definiciones tienen un rol y una naturaleza conceptualmente clarificadora, que las hacen un medio apto para conferir mayor precisión a las expresiones lingüísticas utilizadas en la ley, para una delimitación más rigurosa del tipo penal y para asegurar uniformidad en la aplicación de los tipos. Con todo, esta aptitud para conferir mayor certeza tiene importantes limitaciones y no está del todo exenta de dificultades, ${ }^{199}$ que analizaremos en relación con la definición de material pornográfico en cuya elaboración hubieren sido utilizados menores de dieciocho años.

Preliminarmente, podemos advertir que no parece que los resultados sean muy distintos, en términos de seguridad, en aquellos países en los que no se cuenta con una definición legal pero el término ha sido interpretado jurisprudencialmente aludiendo a criterios objetivos estables y reiterados. ${ }^{200}$

En primer lugar, porque la definición misma se transforma en un ulterior objeto de interpretación; como está compuesta de palabras, puede provocar una incertidumbre posterior en razón del modo como sean interpretadas esas palabras. ${ }^{201}$

Un buen ejemplo de que la existencia de una definición, por sí sola, no puede garantizar la seguridad jurídica es el que ofrece la legislación italiana, que en su art. 529 define los actos y objetos obscenos como "los actos y objetos que, según el sentido común, ofenden el pudor".

198 SAINZ MORENO, "La técnica normativa", cit. nota $\mathrm{n}^{\mathrm{o}} 121$, p. 20. En el mismo sentido, ATIENZA, Contribución, cit. nota $\mathrm{n}^{\circ}$ 107, p. 32 e ITURRALDE SESMA, Victoria, "Cuestiones de técnica legislativa", Revista Vasca de Administración Pública, no 24 (1989), pp. 225-254, p. 225. Todavía más contundente es CALSAMIGLIA, "Justicia", cit. nota no 153, p. 119 cuando advierte que "la recuperación de la previsibilidad, la certeza y la seguridad jurídica es tarea prioritaria, puesto que la disolución de esos valores supone la de los derechos y del Derecho".

${ }^{199}$ Luego de un análisis de las definiciones contenidas en el Derecho penal tributario italiano, PARLATO, Le definizioni legislative, cit. nota $\mathrm{n}^{\circ} 29$, pp. 122-123, concluye que el objetivo de certeza y homogeneidad aplicativa no puede considerarse satisfactoriamente logrado.

${ }^{200}$ Como ha ocurrido en la jurisprudencia de la Corte Suprema de Estados Unidos, a partir del caso Miller v. California de 1973, en que se determina que lo obsceno no depende de lo que consideren las autoridades de los Estados, sino de lo que entienda una persona promedio, y para ello se debe considerar: a) si la obra apela a un interés lascivo; b) si retrata una conducta sexual de una forma patentemente ofensiva, y c) si, en su conjunto, no tiene valor literario, artístico, político o científico serio. United States Supreme Court, 413 U.S. 15 (1973) Disponible en http://caselaw.lp.findlaw.com/scripts/getcase.pl?court=US\&vol=413\&invol=15 [visitado el 15.01.2014]

201 NOLL, "Zur Gesetzestechnik", cit. nota n 47, p. 156; en particular también SÁNCHEZ-OSTIZ, "Relevancia", cit. nota no 30, pp. 218-219. 


\section{Polít. crim. Vol. 9, No 18 (Diciembre 2014), Art. 1, pp. 279-337. \\ [http://www.politicacriminal.cl/Vol_09/n_18/Vol9N18A1.pdf]}

Ya hemos tenido ocasión de hacer breves comentarios sobre algunos de los problemas interpretativos que generan las expresiones empleadas en la definición del art. 366 quinquies inciso segundo, las que no deben juzgarse sólo por la consideración aislada de los conceptos empleados, sino que también es necesario incluir en el juicio las situaciones de hecho que, con la ayuda del concepto, deben ser comprendidas o delimitadas. ${ }^{202} \mathrm{Al}$ determinar el significado de una disposición legal el intérprete no considera únicamente el tenor literal de sus expresiones -aunque existe consenso en que este debe operar como límite dentro del cual se enmarque toda interpretación-, sino que tiene particular relevancia el criterio teleológico, al punto de que algunas disposiciones que parecen redactadas de modo simple y claro pero que no se compadecen con la finalidad que las motiva, sea por exceso o por defecto, terminan haciéndose confusas en su aplicación práctica; y a la inversa, formulaciones que aparecen oscuras en el papel pueden ser corregidas a través de una interpretación que atribuya claridad y univocidad al contenido preceptivo de un texto legal imperfecto. ${ }^{203}$

En este sentido, no debemos engañarnos al proyectar las exigencias de seguridad jurídica sobre la técnica legislativa, porque la certeza del Derecho no es una cualidad que dependa exclusivamente de la disposición legal, sino que la claridad se obtiene en un determinado contexto social y a través de un uso estable. ${ }^{204}$ Esto significa que aun cuando se logre un máximo de determinación en el texto legislativo, en último término los casos claros serán sólo aquéllos en que exista un acuerdo general, una convergencia en las decisiones de la jurisprudencia. ${ }^{205}$ Como no ha transcurrido tiempo suficiente desde su incorporación y modificación, todavía no podemos formular un juicio sobre el modo como ha sido interpretada y aplicada la definición de pornografía infantil, aunque lo que hemos visto hasta ahora es bastante variado.

Así, por ejemplo, encontramos un fallo que, seis años después de la incorporación de la definición legal todavía desconocía su existencia, razón por la cual los jueces determinan lo que debe entenderse por material pornográfico infantil recurriendo a la definición del

\footnotetext{
${ }^{202}$ Cfr. FRISCH, "Le definizioni legali", cit. nota $\mathrm{n}^{\text {o }} 38$, p. 207, en consecuencia, no se debería condenar $a$ priori los tipos que se presentan aparentemente indeterminados o no definidos (p. 208).

203 PALAZZO, Francesco "Orientamenti dottrinali ed effettività giurisprudenziale del principio di determinatezza - tassatività in materia penale", Rivista italiana di Diritto e Procedura Penale (1991), pp. 327-355, pp. 338-339.

${ }^{204}$ Cfr. VIVES ANTÓN, Tomás Salvador, en: COBO DEL ROSAL, Manuel (drg.), Comentarios al Código Penal, Madrid, 1999, p. 507, "la indeterminación de una palabra o de una expresión depende de la medida en que seamos capaces de especificar los supuestos de su aplicación correcta. Por lo tanto, la indeterminación disminuye si tenemos prácticas de uso estables y bien definidas"; concordando con la idea de WITTGENSTEIN, Ludwig, Investigaciones filosóficas, trad.: GARCÍA SUÁREZ, Alfonso; MOULINES, Ulises, Barcelona: Crítica, 1988, §43, de que "el significado de una palabra es el uso que de ella se hace en el lenguaje".

${ }^{205}$ Cfr. ORRÙ, "Le definizioni”, cit. nota n ${ }^{\circ}$ 47, p. 153, con ulteriores referencias; similar SILVA SÁNCHEZ, Jesús María, "La interpretación de las leyes y la cultura de los juristas", en: MONTEALEGRE LYNETT, Eduardo; CARO JOHN, José Antonio (eds.), El sistema penal normativista en el mundo contemporáneo. Libro Homenaje al profesor Günther Jakobs en su 70 aniversario, Bogotá: Universidad Externado de Colombia, pp. 201-213, pp. 208 y ss. En sentido similar SÁNCHEZ-OSTIZ, "Relevancia", cit. nota no 30, p. 224 concluye que "el Derecho penal no se limita sólo con el lenguaje, sino con los hablantes del lenguaje".
} 
OSSANDÓN, María Magdalena. "La técnica de las definiciones en la ley penal:

Análisis de la definición de "material pornográfico en cuya elaboración hubieren sido utilizados menores de dieciocho años".

diccionario de la Real Academia Española, a la del Protocolo Facultativo y a los criterios doctrinalmente establecidos. $^{206}$

En otros, por el contrario, se reconoce que en el delito de producción de material pornográfico infantil la determinación de su objeto se hace en función de lo estipulado en la parte final del artículo 366 quinquies, y no de lo que dice la Ley sobre calificación de la producción cinematográfica, por lo que se satisfacen los requisitos del concepto al estar frente a una representación de las partes genitales de los menores con fines primordialmente sexuales, sin que se requiera un especial ánimo de procurar la excitación de terceros. ${ }^{207}$

Cuestión más delicada es la de cómo se tienen por probados esos fines primordialmente sexuales, lo que se ha resuelto, por ejemplo, dando por configurado el delito porque el imputado participó en la producción de material pornográfico utilizando menores de edad de 13 años-, "a quienes fotografiaba desnudos y exhibiendo sus genitales con fines primordialmente sexuales, no constando en autos que la representación de los genitales de los menores se haya hecho con fines artísticos o científicos"; ${ }^{208}$ es decir, prácticamente se entiende acreditada la finalidad sexual por no existir una finalidad diferente (cabe advertir que solo en una de las fotos un menor tiene su pene erecto, mientras que en las otras solo se muestran los genitales). A diferencia de este caso, en otro se toma en cuenta un conjunto de factores que demostrarían que la filmación no obedecía, como dijo el acusado, al deseo de guardar un recuerdo de los encuentros íntimos de la pareja, sino que a un dolo específico de realizar una producción pornográfica, buscando obtener imágenes lascivas, pues el agente:

"no sólo se limitó a llevar una cámara al motel sino que además hizo acercamiento a la misma de los genitales de la menor, se rasuró el vello como lo hacen los actores profesionales de estas producciones pornográficas. Asimismo estos juzgadores pudieron observar en el filme como el acusado daba instrucciones a la menor, ubicándola frente a la filmadora y grabando a través de acercamientos efectuados con el lente, la zona genito anal de la agredida, de lo que puede apreciarse un contenido groseramente libidinoso". 209

De este modo, prácticamente se hace coincidir el concepto con aquel contenido en el art. $2^{\circ}$ de Ley $\mathrm{N}^{\mathrm{o}} 19.846$, sobre calificación de la producción cinematográfica.

Al interpretar los términos de la definición legal hay que considerar también que la del art. 366 quinquies es una definición con un marcado carácter extensional, pues pretende definir indicando las hipótesis a las que se aplica. Es indudable que se trata de un registro sustitutivo de la definición legislativa y no de una mera enumeración explicativa de un género de hipótesis. En otras palabras, esto significa que los supuestos incluidos dentro del concepto son únicamente los tres que contempla el citado artículo y no pueden

\footnotetext{
${ }^{206}$ STOP de Valparaíso de 14 de mayo de 2010, RIT 12-2010.

${ }^{207}$ SCA de Chillán, de 13 de octubre de 2006, Rol 118-2006 y SCA de Concepción, de 12 de mayo de 2006, Rol 201-2006.

${ }^{208}$ SCA de Concepción, de 12 de mayo de 2006, Rol 201-2006.

${ }^{209}$ STOP de San Antonio, de 4 de julio de 2006, Rol 18-2006.
} 


\section{Polít. crim. Vol. 9, No 18 (Diciembre 2014), Art. 1, pp. 279-337. \\ [http://www.politicacriminal.cl/Vol_09/n_18/Vol9N18A1.pdf]}

individualizarse otros a través de un razonamiento analógico, por más que nos encontremos frente a casos de similar o, incluso, mayor gravedad que los descritos. En este sentido, por lo tanto, la definición no presenta problemas.

Pero su carácter extensional dificulta la identificación del bien jurídicamente protegido por los delitos en que ella incide, cuestión a la que ya hemos aludido. En términos de seguridad jurídica esto incide negativamente, pues permite que cada tribunal identifique el bien jurídico que le parece más adecuado para, eventualmente, dejar de aplicar las disposiciones si estima que un hecho particular no satisface los requisitos relativos a la antijuridicidad material $^{210}$ del delito.

Por otra parte, la ganancia en seguridad jurídica está condicionada a que se mantenga el mismo significado para el término en todas las normas en que es empleado. Esta regla no debería ser difícil de aplicar en el ámbito de una ley, pero la dificultad aumenta si se extiende a un sector del ordenamiento o a éste en su totalidad, y ya hemos visto que en relación con lo que se entiende por material pornográfico esto se cumple solo a medias. Al menos es rescatable que la misma norma que contiene la definición de material pornográfico en cuya elaboración hubieren sido utilizados menores de dieciocho años delimite bien su ámbito de aplicación -solo a los delitos descritos en los artículos 366 quinquies inciso primero y 374 bis-, precisando así su valor normativo y sistemático.

Para conseguir un adecuado nivel de seguridad es preciso, también, que las disposiciones penales gocen de cierta permanencia o estabilidad, en tanto que:
"las transformaciones frecuentes -ya estén bien fundadas y materialmente justificadas, ya sean convulsiones violentas que afectan al Derecho- son desfavorables al desarrollo del Derecho, pues impiden que se produzca aquel sentimiento de protección y confianza que constituye el ideal de la seguridad jurídica". ${ }^{211}$

Esperamos que, pasada la agitación de sus inicios, la definición del art. 366 quinquies inciso segundo goce de una mayor estabilidad.

Para terminar estas consideraciones relativas a la seguridad jurídica, recogemos la conclusión a la que llega Pablo Sánchez-Ostiz cuando analiza la relevancia de las definiciones legales en la aplicación del Derecho penal, plenamente aplicable al caso que nos ocupa. Esto es, "que las definiciones pueden servir para acotar y limitar un ámbito conceptual. Pero difícilmente para lograr un Derecho penal más limitado o restringido, como cabría esperar de tal técnica". En efecto, las definiciones legales son de carácter estipulativo, apuntan a la coherencia del sistema y "si de lo que se trata es de salvar el

\footnotetext{
${ }^{210}$ La que no debe confundirse con la mera ausencia de causas de justificación, como parece hacer la SCA de Concepción, de 12 de mayo de 2006, Rol 201-2006 cuando descarta los argumentos de la defensa en torno a la falta de antijuridicidad y afirma que "[e]s sabido que toda conducta típica es antijurídica a menos que concurran respecto de ella causales de justificación, circunstancia que no se encuentra acreditada en la situación en estudio", si bien continúa luego sosteniendo que se ha afectado el bien jurídicamente protegido en el sentido exigido por el tipo penal.

${ }^{211}$ LASCURAÍN SÁNCHEZ, José Antonio, Sobre la retroactividad penal favorable, Madrid: Civitas, 2000, p. 96.
} 
OSSANDÓN, María Magdalena. "La técnica de las definiciones en la ley penal:

Análisis de la definición de "material pornográfico en cuya elaboración hubieren sido utilizados menores de dieciocho años".

sistema, éste tenderá a dar cabida a la definición, cuando no a redefinir los conceptos para evitar la obsolescencia. Con lo cual, las definiciones, que habían sido presentadas como medio para un Derecho penal garantista, se convierten fácilmente en el medio para ampliarlo a merced de las circunstancias". ${ }^{212}$

Precisamente, la definición contenida en el art. 366 quinquies, aunque pueda servir para delimitar el término en cuestión y disipar dudas en relación con algunas hipótesis particulares, no asegura una restricción del Derecho penal. Ella fue incorporada en nuestra legislación para ampliar el ámbito de aplicabilidad de los delitos relativos a la pornografía infantil, ${ }^{213}$ y como plantea algunos problemas interpretativos, incoherencias con el sistema normativo en que se inserta y una poco afortunada conexión con la finalidad de protección, pueden terminar siendo una nueva fuente de inseguridad.

\section{A modo de conclusión, consideraciones de justicia}

Asumimos la justicia como la cima del análisis, como el criterio que sirve para ordenar todos los demás; porque la justicia no constituye un valor consistente y estable que se sume a los otros criterios para enjuiciar una determinada técnica legislativa, sino que se integra con esos valores para equilibrarlos de modo proporcionado en el supuesto concreto. La justicia puede considerarse, por tanto, un valor de totalidad.

Desde esta perspectiva, debemos partir por reconocer que entre los criterios que se han venido planteando existen relaciones de interdependencia y colaboración, pero también de tensión e incompatibilidad, pues "están implicadas diversas nociones de racionalidad que transcurren en sentidos distintos; no sólo no es fácil, sino que quizás sea imposible satisfacer al mismo tiempo (y, a veces, ni siquiera por separado) las exigencias que plantean estas diversas nociones de racionalidad". ${ }^{214}$ Simplificando al máximo, en teoría las contradicciones fundamentales surgen entre los aspectos garantísticos -el respeto por la subsidiariedad, proporcionalidad, igualdad, seguridad jurídica y legitimación democráticaen contraposición con la finalidad preventiva, es decir, con la efectiva protección de los bienes jurídicos; en otras palabras, se trata de la tensión entre libertad y seguridad. En esta encrucijada, el empleo de una técnica legislativa será tanto más justa cuanto más se aproxime al cumplimiento completo de estas dos directrices.

La decisión de incluir una definición legal expresa de lo que se entiende por material pornográfico en cuya elaboración hubieren sido utilizados menores de dieciocho años parece que podría ser positivamente valorada desde una perspectiva garantista, porque radica la decisión en el legislador-legitimidad democrática-, de un modo que, en principio, podría asegurar una mayor seguridad jurídica y uniformidad en la aplicación del Derecho. Estos son valores fundamentales que podrán compensar los inconvenientes que su inclusión genera en aspectos formales de economía o de sistematicidad.

\footnotetext{
${ }^{212}$ SÁNCHEZ-OSTIZ, "Relevancia”, cit. nota no 30, p. 215.

${ }^{213}$ Vid. supra nota $\mathrm{n}^{\mathrm{o}} 25$.

${ }^{214}$ ATIENZA, Contribución, cit. nota no 107, p. 56.
} 
Polít. crim. Vol. 9, No 18 (Diciembre 2014), Art. 1, pp. 279-337.

[http://www.politicacriminal.cl/Vol_09/n_18/Vol9N18A1.pdf]

Sin embargo, el análisis de fondo ha demostrado que hay dos aspectos que resultan especialmente criticables, desde diversos puntos de vista: el primero, prescindir de la diferenciación por edad de los menores involucrados, para reconocer valor a su consentimiento; y el segundo, el afán por ampliar su ámbito de aplicación incluyendo situaciones de diversa gravedad. Esto ha terminado por desdibujar la finalidad de las normas en que la definición opera, lo que propicia una aplicación menos eficiente, menos igualitaria, desproporcionada en ciertos casos y, en definitiva, que no garantiza la seguridad jurídica a la que se podía aspirar. 
OSSANDÓN, María Magdalena. "La técnica de las definiciones en la ley penal: Análisis de la definición de "material pornográfico en cuya elaboración hubieren sido utilizados menores de dieciocho años".

\section{BIBLIOGRAFÍA}

AGUADO CORREA, Teresa, El principio de proporcionalidad en Derecho penal, Madrid: Edersa, 1999.

ALCÁCER GUIRAO, Rafael, "Facticidad y normatividad. Notas sobre la relación entre ciencias sociales y Derecho penal", Actualidad Penal (2001), pp. 229-261.

ALCHOURRÓN, Carlos; BULYGIN, Eugenio, "Definiciones y normas", en: BULGYN, Eugenio et al. (comps.), El lenguaje del Derecho. Homenaje a Genaro Carrió, Buenos Aires: Abeledo Perrot, 1983, pp. 11-42.

ANTOLISEI, Francesco, Manuale di Diritto penale. Parte Generale, $14^{\mathrm{a}}$ ed., Milano: Giuffrè, 1997.

ATIENZA, Manuel, Contribución a una teoría de la legislación, Madrid: Civitas, 1997. , El sentido del Derecho, Barcelona: Ariel, 2001.

BARAHONA NOVOA, Alberto, "Aproximaciones a la definición jurídica", Kañina, Revista Artes y Letras, U. Costa Rica, XXXIII, Especial (2009), pp. 47-56.

BELVEDERE, Andrea, "Note in tema di definizioni legislative penalistiche", en: CADOPPI, Alberto (coord.), Omnis definitio in iure periculosa? Il problema delle definizioni legali nel Diritto penale, Padova: Cedam, 1996, pp. 109-124.

BRICOLA, Franco, "Le definizioni normative nell'esperienza dei codici penali contemporanei e nel progetto di delega italiano", en: CADOPPI, Alberto (coord.), Omnis definitio in iure periculosa? Il problema delle definizioni legali nel Diritto penale, Padova: Cedam, 1996, pp. 175-190.

CADOPPI, Alberto, Il problema delle definizioni legali nel Diritto penale. Presentazione, en: CADOPPI (coord.), Omnis definitio in iure periculosa? Il problema delle definizioni legali nel Diritto penale, Padova: Cedam, 1996

CALSAMIGLIA, Albert, "Justicia, eficiencia y optimización de la legislación", Documentación Administrativa No 218-219 (1989), p. 113-151

CAPELLA, Juan Ramón, "Notas sobre la definición legal", Anuario de filosofía del derecho, $\mathrm{N}^{\mathrm{o}} 10$ (1963), pp. 37-50

, El derecho como lenguaje, Ariel: Barcelona, 1968

CARNEVALI RODRÍGUEZ, Raúl, "Algunas precisiones respecto de los delitos de producción de material pornográfico infantil, de favorecimiento a la prostitución de menores y de obtención de servicios sexuales", Informe en Derecho $N^{\circ} 2 / 2012$, Departamento de Estudios, Defensoría Penal Pública, 2012, pp. 1-19. Disponible en http://www.biblio.dpp.cl/biblio/DataBank/6670-2.pdf [visitado el 20.12.2013]

CARRIÓ, Genaro, Notas sobre derecho y lenguaje, $2^{\mathrm{a}}$ ed., Buenos Aires: Abeledo Perrot, 1979.

CISTERNAS VELIS, Luciano Alberto, El delito de producción de pornografía infantojuvenil como lesión a la intimidad y el honor de los menores de edad. Análisis doctrinal de las consecuencias en el ámbito concursal, Valparaíso: Tesis de Magíster, Pontificia Universidad Católica de Valparaíso, 2013.

COHEN, Morris; NAGEL, Ernest, Introducción a la lógica y al método científico, trad.: MIGUEZ, Nestor, $2^{a}$ ed. en castellano, Buenos Aires: Amorrortu, 1971.

COPI, Irving; COHEN, Carl, Introducción a la lógica, trad. de la $8^{\mathrm{a}}$ edición: GONZÁLEZ RUIZ, Edgar; CHÁVEZ CALDERÓN, Pedro, México: Limusa, 1995. 
Polit. crim. Vol. 9, № 18 (Diciembre 2014), Art. 1, pp. 279-337.

[http://www.politicacriminal.cl/Vol_09/n_18/Vol9N18A1.pdf]

COX LEIXELARD, Juan Pablo, "Los delitos de producción, adquisición y tenencia maliciosa de material pornográfico como figuras expansivas del Derecho penal, Revista de Derecho, PUCV Semestre I (2005), pp. 145-154.

, Los abusos sexuales, Santiago: Lexis Nexis, 2003.

DE LA FUENTE JIMÉNEZ, Claudia, Delitos de pornografía infantil, Santiago: Legal Publishing, 2008.

DÍEZ RIPOLLÉS, José Luis, "El derecho penal simbólico y los efectos de la pena", Actualidad Penal (2001), pp. 1-22.

, Exhibicionismo, pornografía y otras conductas sexuales provocadoras, Barcelona:

Bosch, 1982.

DONNA, Edgardo Alberto, Delitos contra la integridad sexual, Buenos Aires: RubinzalCulzoni, 2000.

, Derecho penal. Parte especial, tomo I, Buenos Aires: Rubinzal-Culzoni, 1999.

EMANUELE, Pier Paolo, Le tecniche di redazione della legge penale nel quadro dei principi costituzionali, Tesis doctoral, Università degli studi di Milano, Facoltà di giurisprudenza, 2009-2010, disponible en http://air.unimi.it [visitado el 19.12.2013]

FALCÓN Y TELLA, María José, Concepto y fundamento de la validez del Derecho, Madrid: Universidad Complutense, 1994.

FERRAJOLI, Luigi, Derecho y razón. Teoría del garantismo penal, trad.: ANDRÉS IBÁÑEZ, Perfecto et al., Madrid: Trotta, 1995.

FRISCH, Wolfgang, "Le definizioni legali nel diritto penale tedesco", en: CADOPPI, Alberto (coord.), Omnis definitio in iure periculosa? Il problema delle definizioni legali nel Diritto penale, Padova: Cedam, 1996, pp. 191-238.

GRETEL, La forma de las leyes. 10 estudios de técnica legislativa, Introducción, Barcelona: Bosch, 1986.

GUASTINI, Riccardo, "Redazione e interpretazione dei documenti normativi", en: BARTOLE (a cura di), Lezioni di tecnica legislativa, Padova: Cedam, 1988, pp. 37117.

HART, H.L.A., The Concept of Law, I, 3, 2a ed., Oxford: Oxford University Press, 1994.

HERNÁNDEZ MARÍN, Rafael, Introducción a la teoría de la norma jurídica, $2^{\mathrm{a}}$ ed., Madrid-Barcelona: Marcial Pons, 2002.

ITURRALDE SESMA, Victoria, Lenguaje legal y sistema jurídico, Madrid: Tecnos, 1989.

JAKOBS, Günther, Derecho penal. Parte General, trad.: CUELLO CONTRERAS, Joaquín; SERRANO GONZÁLEZ DE MURILLO, José Luis, Madrid: Marcial Pons, 1995.

JORI, Mario, "Definizioni legislativa e pragmatica giuridica", en: CADOPPI, Alberto (coord.), Omnis definitio in iure periculosa? Il problema delle definizioni legali nel Diritto penale, Padova: Cedam, 1996, pp. 55-93.

KAUFMANN, Arthur, Filosofía del Derecho, trad.: VILLAR BORDA, Luis; MONTOYA, Ana María, Bogotá: Universidad del Externado, 1999.

KÜNSEMÜLLER, Carlos, "Delitos de pornografía infantil (modificaciones legales anunciadas y problemas ad portas)", Gaceta Jurídica N² 273 (2003), pp. 7-13.

LARENZ, Karl, Metodología de la Ciencia del Derecho, trad.: RODRÍGUEZ MOLINERO, Barcelona: Ariel, 1994.

LASCURAÍN SÁNCHEZ, José Antonio, Sobre la retroactividad penal favorable, Madrid: Civitas, 2000. 
OSSANDÓN, María Magdalena. "La técnica de las definiciones en la ley penal: Análisis de la definición de "material pornográfico en cuya elaboración hubieren sido utilizados menores de dieciocho años".

LASSERRE-KIESOW, Valérie, La technique législative. Étude sur les Codes Civils français et allemand, Paris: Librairie Générale de Droit et de Jurisprudence, 2000.

MANTOVANI, Ferrando, "Il principio di offensività nello schema di delega legislativa per un nuovo Codice Penale", Rivista italiana di Diritto e Procedura Penale (1997), pp. 313-337

MARCILLA CÓRDOBA, Gema, Racionalidad legislativa, Madrid: Centro de estudios políticos y constitucionales, 2005.

MARINUCCI, Giorgio; DOLCINI, Emilio, Corso di Diritto penale, I, $3^{\mathrm{a}}$ ed., Milano: Giuffrè, 2001.

MARTINO, Antonio Anselmo, "Definiciones legales", en: WARAT, Luis Alberto; MARTINO, Antonio Anselmo, Lenguaje y definición jurídica, Buenos Aires: Cooperadora de Derecho y Ciencias Sociales, 1973, pp. 59-90.

MOLINA CANTILLANA, René, Delitos de pornografía infantil, Santiago: Librotecnia, 2008.

MONTORO BALLESTEROS, Alberto, El Derecho como sistema normativo: naturaleza y función del Derecho, Murcia: Universidad de Murcia, 1993.

MORALES PRATS, Fermín, "Omnis definitio in iure periculosa? El problema de las definiciones en el Código penal español y en el Proyecto de Código penal de 1992", en: CADOPPI, Alberto (coord.), Omnis definitio in iure periculosa? Il problema delle definizioni legali nel Diritto penale, Padova: Cedam, 1996, pp. 275-331.

, "Pornografía infantil e internet", Ponencia presentada en las Jornadas de Responsabilidad Civil y Penal de los Prestadores de Servicios en Internet, organizadas por la UOC y el Ilustre Colegio de Abogados de Barcelona, Barcelona, 22-23 de noviembre de 2001. Disponible en http://www.uoc.edu/in3/dt/20056/20056.pdf

MORALES PRATS, Fermín; GARCÍA ALBERO, Ramón, "Delitos contra la libertad e indemnidad sexual”, en: QUINTERO OLIVARES, Gonzalo (dir.), Comentarios a la Parte Especial del Derecho penal, $8^{\text {a }}$ ed., Pamplona: Aranzadi - Thomson Reuters, 2009, pp. 283-380.

MORILLAS FERNÁNDEZ, David Lorenzo, Análisis dogmático y criminológico de los delitos de pornografía infantil, Madrid: Dykinson, 2005.

MUÑOZ CONDE, Francisco, Derecho Penal. Parte Especial $16^{\mathrm{a}}$ ed., Valencia: Tirant lo Blanch, 2007.

MUÑOZ QUESADA, Hugo Alfonso, "La situación de la técnica legislativa en Costa Rica", en: RODRÍGUEZ CHANG, Ronny (ed.), La técnica legislativa en Centroamérica y República Dominicana, San José, Costa Rica: Instituto Interamericano de Derechos Humanos, 2000, pp. 73-153.

NAVARRO FRIAS, Irene, "Técnica legislativa y Derecho penal", Estudios Penales y Criminológicos, vol. XXX (2010), pp. 219-267, pp. 238-243.

NINO, Carlos Santiago, Introducción al análisis del Derecho, 4ª ed., Barcelona: Ariel, 1991.

OLIVER CALDERÓN, Guillermo, Delitos contra la propiedad, Santiago: Legal Publishing, 2013. 
Polit. crim. Vol. 9, № 18 (Diciembre 2014), Art. 1, pp. 279-337.

[http://www.politicacriminal.cl/Vol_09/n_18/Vol9N18A1.pdf]

ORRÙ, Giovanni, "Le definizioni del legislatore e la ridefinizioni della giurisprudenza", en: CADOPPI, Alberto (coord.), Omnis definitio in iure periculosa? Il problema delle definizioni legali nel Diritto penale, Padova: Cedam, 1996, pp. 147-161.

ORTS BERENGUER, Enrique, "Delitos contra la libertad e indemnidad sexuales (y III): Exhibicionismo y provocación sexual. Prostitución y corrupción de menores”, en: VIVES ANTÓN, Tomás Salvador et al., Derecho Penal. Parte especial, $3^{\mathrm{a}}$ ed., Valencia: Tirant lo Blanch, 2010, pp. 279-310.

OSSANDÓN WIDOW, M. Magdalena, "Sobre la calidad de empleado público en los delitos funcionarios y la punibilidad de quienes no la poseen", Revista Doctrina y Jurisprudencia Penal, Facultad de Derecho, Universidad de Los Andes y Abeledo Perrot-Legal Publishing, $N^{\circ} 8$ (2012), pp. 45-82. , La formulación de tipos penales, Santiago: Editorial Jurídica de Chile, 2009.

OXMAN, Nicolás, "Aspectos político-criminales y criminológicos de la criminalización de la posesión de pornografía infantil en Estados Unidos de Norteamérica", Polít. crim. Vol. 6, $\quad \mathrm{N}^{\mathrm{o}} 12$ (2011), A2, pp. 252-294. Disponible en http://www.politicacriminal.cl/Vol_06/n_12/Vol6N12A2.pdf [visitado el 05.01.2014]

PALAZZO, Francesco, "Orientamenti dottrinali ed effettività giurisprudenziale del principio di determinatezza - tassatività in materia penale", Rivista italiana di Diritto e Procedura Penale (1991), pp. 327-355, pp. 338-339.

, "Sulle funzioni delle norme definitorie", en CADOPPI, Alberto (coord.), Omnis definitio in iure periculosa? Il problema delle definizioni legali nel Diritto penale, Padova: Cedam, 1996, pp. 381-390.

, "La legalidad en la Europa de Amsterdam", trad.: GARCÍA RIVAS, Nicolás, Revista penal, No 3, 1999, pp. 36-41.

PARLATO, Maria Concetta, Le definizioni legislative nel sistema penale tributario, Bari: Cacucci Editore, 2012.

QUINTERO OLIVARES, Gonzalo, Parte general del Derecho penal, Elcano, Navarra: Aranzadi, 2005.

ROBINSON, Paul H.; GREENE, Peter D.; GOLDSTEIN, Natasha R., "Making Criminal Codes Functional: A Code of Conduct and a Code of Adjudication", The Journal of Criminal Law and Criminology 86 (1996), pp. 304-365.

ROBINSON, Paul H., "Rules of Conduct and Principles of Adjudication", Chicago Law Review 57 (1990), pp. 729-771.

ROBINSON, Richard, Definition, Oxford: Oxford University Press, 1954.

RODRÍGUEZ COLLAO, Luis, Delitos sexuales, Santiago: Editorial Jurídica de Chile, 2000.

RODRÍGUEZ COLLAO, Luis; MAYER LUX, Laura, "La conducta típica del delito de producción de pornografía infanto-juvenil”, Revista Doctrina y Jurisprudencia penal: Delitos sexuales, № 15 (2013), pp. 25-41.

RODRÍGUEZ DÍEZ, José, "Versión española de las Reglas jurídicas del Corpus de Derecho Canónico", Anuario Jurídico y Económico Escurialense, XLI (2008), pp. 287-312.

ROSS, Alf, "La definizione nel linguaggio giuridico", en: SCARPELLI (a cura di), Diritto e analisi del linguaggio, Milano: Ed. Comunita, 1976, pp. 199-214.

, Sobre el derecho y la justicia, trad.: CARRIÓ, Genaro, $2^{\mathrm{a}}$ ed., Buenos Aires: Eudeba, 1997. 
OSSANDÓN, María Magdalena. "La técnica de las definiciones en la ley penal: Análisis de la definición de "material pornográfico en cuya elaboración hubieren sido utilizados menores de dieciocho años".

ROXIN, Claus, Política criminal y sistema del Derecho penal, $2^{\mathrm{a}}$ ed., trad. MUÑOZ CONDE, Francisco, Buenos Aires: Hammurabi, 2000.

SAINZ MORENO, Fernando, "La técnica normativa: visión unitaria de una materia plural", en: CORONA FERRERO, Jesús María; PAU VALL, Francesc; TUDELA ARANDA, José (coords.), La técnica legislativa a debate, Madrid: Tecnos, 1994, pp. 19-47. , "Los textos normativos. Condiciones de inteligibilidad", en: AA. VV., Actualidad y perspectivas del Derecho público a fines del siglo XX: Homenaje al profesor Garrido Falla, vol. I, Madrid: Ed. Complutense, 1992, pp. 441-471.

, voz "seguridad jurídica", en: MONTOYA MELGAR, Alfredo (dir.), Enciclopedia jurídica básica, t. IV, Madrid: Civitas, 1995.

SALVADOR CODERCH, Pablo, "Definiciones y remisiones", en: SAINZ MORENO, Fernando; DA SILVA OCHOA, Juan Carlos (coords.), La calidad de las leyes, Vitoria: Parlamento Vasco, 1989, pp. 157-182.

SÁNCHEZ LÁZARO, Fernando-Guanarteme, “¿Cómo se elabora una propuesta de lege ferenda? Reflexiones sobre la formulación de los preceptos jurídico-penales. Primera parte: tipicidad", Revista de Derecho penal y criminología, 2a Época, № 16 (2005), pp. 79-137.

SÁNCHEZ PECAREVIC, Claudio, Delito de almacenamiento de pornografía infantil, Santiago: Librotecnia, 2010.

SÁNCHEZ-OSTIZ GUTIÉRREZ, Pablo, "Relevancia de las definiciones legales en la aplicación del Derecho penal” en: MONTIEL, Juan Pablo (ed.), La crisis del principio de legalidad en el nuevo Derecho penal: ¿decadencia o evolución?, Madrid: Marcial Pons, 2012, pp. 207-224.

SCARPELLI, Uberto, "La definizione nel diritto", en: SCARPELLI (a cura di), Diritto e analisi del linguaggio, Milano: Ed. Comunita, 1976, pp. 183-197

SCHÄFFER, Heinz, "Racionalización y creación del Derecho", trad.: MONTORO CHINER, María Jesús, Documentación administrativa No 218-219 (1989), pp. 153195

SEMERARO, Pietro, "Definizioni e funzione di garanzia della legge penale, en: CADOPPI, Alberto (coord.), Omnis definitio in iure periculosa? Il problema delle definizioni legali nel Diritto penale, Padova: Cedam, 1996, pp. 495-498

SGARBI, Adrian, "What Is a Good Legislative Definition?", Beijing Law Review, Vol.4, $\mathrm{N}^{\circ} 1$ (2013), pp. 28-36, p. 28, en: http://www.scirp.org/journal/blr [visitado el 13.12.2013].

SILVA SÁNCHEZ, Jesús María, "La interpretación de las leyes y la cultura de los juristas", en: MONTEALEGRE LYNETT, Eduardo; CARO JOHN, José Antonio (eds.), El sistema penal normativista en el mundo contemporáneo. Libro Homenaje al profesor Günther Jakobs en su 70 aniversario, Bogotá: Universidad Externado de Colombia, pp. 201-213.

,"Eficiencia y Derecho penal", ADPCP (1996), pp. 93-127.

, Aproximación al Derecho penal contemporáneo, Barcelona: Bosch, 1992.

TAMARIT SUMALLA, Josep Maria, La protección penal del menor frente al abuso y la explotación sexual, $2^{\mathrm{a}}$ ed., Pamplona: Aranzadi - Thomson Reuters, 2002.

TAPIA VALDÉS, Jorge, La técnica legislativa, Santiago: Editorial Jurídica de Chile, 1960.

TARELLO, Giovanni, L’interpretazione della legge, Milano: Giuffrè, 1980. 
Polít. crim. Vol. 9, No 18 (Diciembre 2014), Art. 1, pp. 279-337.

[http://www.politicacriminal.cl/Vol_09/n_18/Vol9N18A1.pdf]

TIEDEMANN, Klaus, Tatbestandsfunktionen im Nebenstrafrecht, Tübingen: J. C. B. Mohr, 1969.

VAN WEEZEL, Alex, Error y mero desconocimiento en Derecho penal, Santiago: Legal Publishing, 2008.

VENEGAS CAMPOS, Andrea, Definición legal de material pornográfico en el Código Penal chileno, Memoria para optar al grado de Licenciado en Ciencias Jurídicas, PUCV, 2014.

VERA AZÓCAR, Alejandra; SEPÚLVEDA SÁNCHEZ; Ivonne, "Aproximaciones a los bienes jurídicos protegidos y a las cuestiones concursales en el ámbito de los delitos vinculados a la pornografía infantil”, Revista Jurídica del Ministerio Público, $\mathrm{N}^{\circ} 49$ (2011), pp. 198-205.

VIDAL OLIVARES, Álvaro, "La técnica legislativa y la interpretación de la ley", en: OELCKERS, Osvaldo et. al., La técnica legislativa ante la elaboración de la ley, Valparaíso, CEAL, 1998, pp. 323-349.

VIVES ANTÓN, Tomás Salvador, en: COBO DEL ROSAL, Manuel (drg.), Comentarios al Código Penal, Madrid, 1999.

WILLIAMS, Katherine, "Child Pornography Law: Does it Protect Children?", Journal of Social Welfare and Family Law, $\mathrm{N}^{\circ}$ 26, 3 (2004), pp. 245-261.

WITTGENSTEIN, Ludwig, Investigaciones filosóficas, trad.: GARCÍA SUÁREZ, Alfonso; MOULINES, Ulises, Barcelona: Crítica, 1988.

ZUÑIGA AÑAZCO, Yanira, "El principio de proporcionalidad como herramienta de racionalidad. Un análisis crítico de su aplicación en la jurisprudencia del tribunal constitucional chileno", Revista Ius et Praxis, Año 16, Nº 2 (2010), pp. 249-272. 